\title{
Data report: site surveys in the Bering Sea for Integrated Ocean Drilling Program Expedition 323 (as part of IODP Proposal 477)'
}

\author{
T. Sakamoto, ${ }^{2}$ K. Takahashi, ${ }^{3}$ K. lijima, ${ }^{2}$ Y. Kido, ${ }^{4}$ F. Yamamoto, ${ }^{4}$ T. No, ${ }^{5}$ T. Tsuru, ${ }^{6}$ U. Suzuki, ${ }^{4}$ M. Okada, ${ }^{7}$ \\ Y. Okazaki, ${ }^{8}$ H. Tokuyama, ${ }^{9}$ and A. Taira ${ }^{10}$
}

\section{Chapter contents}

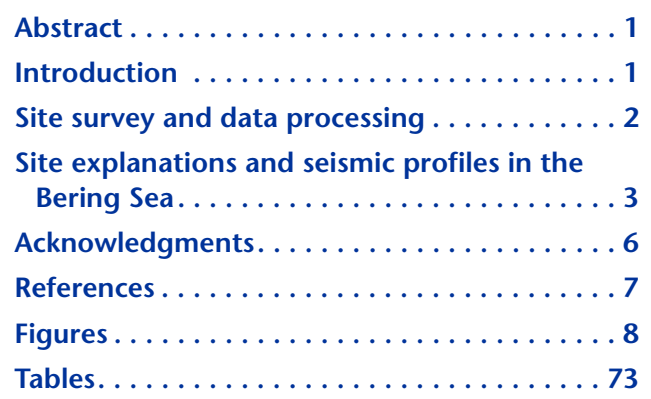

\section{Abstract}

In 2009, Integrated Ocean Drilling Program (IODP) Expedition 323 drilled at seven sites in the Bering Sea. The primary objective of this expedition was to investigate high-resolution paleoceanographic history in the Bering Sea during the past 5 m.y. Expedition 323 was a part of IODP Proposal 477, which included areas of both the Bering and Okhotsk Seas. As part of the proposal, we conducted marine geophysical and geological surveys in the Bering Sea using the R/V Hakuhou-maru. During that cruise, we collected swath bathymetry, subbottom profiles, seismic reflection data, and sediment cores, all of which form the primary site survey data set on which Expedition 323 drill sites are located. This paper presents site survey data collected during the Hakuhou-maru survey with available survey data from other cruises.

\section{Introduction}

\footnotetext{
${ }^{1}$ Sakamoto, T., Takahashi, K., lijima, K., Kido, Y., Yamamoto, F., No, T., Tsuru, T., Suzuki, U., Okada, M., Okazaki, Y., Tokuyama, H., and Taira, A., 2011. Data report: site surveys in the Bering Sea for Integrated Ocean Drilling Program Expedition 323 (as part of IODP Proposal 477). In Takahashi, K., Ravelo, A.C., Alvarez Zarikian, C.A., and the Expedition 323 Scientists, Proc. IODP, 323: Tokyo (Integrated Ocean Drilling Program Management International, Inc.).

doi:10.2204/iodp.proc.323.111.2011

2 Institute of Biogeosciences, JAMSTEC, Yokosuka 237-0061, Japan. Correspondence author: tats-ron@jamstec.go.jp

${ }^{3}$ Department of Earth and Planetary Sciences, Kyushu University, Fukuoka 812-8581, Japan. ${ }^{4}$ Center for Deep Earth Exploration, JAMSTEC, Yokohama 236-0001, Japan.

${ }^{5}$ Institute for Research on Earth Evolution, JAMSTEC, Yokosuka 237-0061, Japan.

${ }^{6}$ Cosmo Oil Company, Ltd., Japan.

${ }^{7}$ Department of Environmental Sciences, Ibaraki University, Ibaraki 310-8512, Japan.

${ }^{8}$ Research Institute for Global Change, JAMSTEC, Yokohama 236-0001, Japan.

${ }^{9}$ Atmosphere and Ocean Research Institute, University of Tokyo, Chiba 277-8564, Japan. ${ }^{10}$ JAMSTEC, Yokosuka 237-0061, Japan.
}

The paucity of data in critical regions of the Pacific such as the Bering and Okhotsk Seas has prevented an evaluation of the role of North Pacific processes in global climate change. The Bering and Okhotsk Seas are marginal North Pacific basins that store in their thick sedimentary sequences a record of major past climate changes. Because Pacific intermediate water is formed in these basins, they are not just recorders of but are potentially critically involved in causing major climate changes. Thus, drilling in these two marginal backarc seas will answer questions not just about the global extent of climate trends and oscillations but also about the mechanisms that produce them.

Integrated Ocean Drilling Program (IODP) Proposal 477 proposed to drill sediment appropriate for a detailed study of the PliocenePleistocene evolution of millennial- to orbital-scale climatic oscillations recorded in the Bering and Okhotsk Seas. Biological, chemical, and physical oceanography as well as adjacent continental climate are highly sensitive to global climate conditions and are recorded by variations in the sedimentary composition of diatoms and other microfossil groups, as well as many other pagions can be tracked using paleoceanographic proxies of subsurface water that can be related to open Pacific records. Sediments can be used not only to extract records of climate and intermedileoclimatic indicators. Intermediate water formation in these re- 
ate water ventilation in these high-latitude marginal seas but they can also be applied to interrogate the effect of oceanographic changes imposed at the Bering Strait Gateway (through the Arctic) on heat and nutrient partitioning between the Atlantic and $\mathrm{Pa}$ cific Oceans. The proposed drilling would, for the first time, provide continuous and high-resolution paleoenvironmental records from these subboreal seas. These new records would reveal and test our understanding of the processes that influence intermediate water ventilation and its role in global climate change over the past 5 m.y.

IODP Proposal 477 was first submitted in June 1995 to the Ocean Drilling Program (ODP). The proposal was transferred to IODP and subsequently approved for drilling by the IODP-Science Advisory StructureScience Steering and Evaluation Panel (IODP-SASSSEP) in May 2004. The IODP-SAS-Science Planning Committee (SPC) recommended the proposal for ranking in June 2004 and forwarded it to Operations Committee/Operations Task Force (OPCOM/OTF). The proposal was initially reviewed by the Environmental Protection and Safety Panel (EPSP) on June 2005 (in Edinburgh, Scotland) and approved in December 2005 (in Hawaii, USA). Taking into account discussions with IODP-SAS-Site Survey Panel (SSP) and EPSP, all the available site survey data sets were processed. These included original site survey data (navigation, subbottom profile, and seismic reflection) of Cruise KH99-03 (R/V Hakuhou-maru) responding to the request by the EPSP (in 2005 and 2006) to provide them using consistent procedures for proposed sites in the Bering Sea. We updated corrected data sets of navigation, swath bathymetry map by narrow-beam bathymetric operations, 3.5 $\mathrm{kHz}$ subbottom profiles, and reprocessed multichannel seismic (MCS) reflection profiles of site-specific cross-line surveys. All advance-processed data sets were uploaded to the IODP Site Survey Database (SSDB).

This document contains information about all processed data sets submitted in support of proposed drilling sites in the Bering Sea, some of which were drilled during IODP Expedition 323 (Table T1; Fig. F1).

\section{Site survey and data processing}

\section{Progress of collecting site survey data sets}

Initially, the bulk of the seismic profiles in the Bering Sea presented in IODP Proposal 477 were collected by U.S. expeditions (USNS Bartlett in 1970 and R/V Lee in 1980) (Fig. F2). In August 1999, new site sur- vey data were specifically collected for proposed sites on Bowers Ridge (BOW), over the continental slope (Beringian margin) of the Aleutian Basin (GAT; gateway sites to the Arctic Ocean), and Umnak Plateau (UMK) during Cruise KH99-3 Leg 3 of the Hakuhoumaru (formerly operated by Ocean Research Institute, the University of Tokyo and now by the Japan Agency for Marine-Earth Science and Technology [JAMSTEC]) (Fig. F2).

\section{Cruise KH99-3 Leg 3}

Cruise KH99-3 Leg 3 was conducted from 29 July to 25 August 1999 (Takahashi, 2005). During the cruise, high-resolution swath bathymetry and MCS data and sediment cores were collected in support of IODP Proposal 447.

\section{High-resolution swath mapping}

High-resolution swath mapping was conducted using the SeaBeam 2120HR system and Integrated Global Positioning System (GPS)/Inertial Navigation systems installed on the Hakuhou-maru. The accuracy of the depth measurement is $\sim 0.1 \%$ of the water depth. A positioning and orientation system for marine vessels (POS/MV) integrated navigation system and orientation system was used to monitor the ship motion in all three axes. GPS positions were acquired based on the World Geodetic 1984 (WGS84) system. A $3.5 \mathrm{kHz}$, high-resolution profile was also collected. Swath mapping was conducted over BOW, GAT, and UMK sites.

\section{Multichannel seismic survey}

MCS profiles were recorded as described in Table T2. Two air guns were deployed, a $3000 \mathrm{~cm}^{3}$ gun on the port side and an $1800 \mathrm{~cm}^{3}$ system to starboard. See SURVEY in "Supplementary material" for multichannel seismic data in SEG-Y format.

\section{Sediment coring}

Sea-bottom sediments were collected using a piston and multiple corers provided by Ocean Research Institute (ORI), University of Tokyo.

\section{Seismic velocity and target depth estimation}

In order to estimate target drilling depths for proposed sites, we used velocity measurement on sediment cores recovered during Deep Sea Drilling Project (DSDP) Leg 19 (Creager, Scholl, et al., 1973). In addition, we applied stacking MCS velocity data from United States Geological Society (USGS) Cruise 
L6-80 of the R/V Lee and UMK-3A Line 6. Velocity controls and estimated penetration depths are included in the seismic profiles shown for each proposed site. For GAT and BOW sites, velocity analyses were applied during the reprocessing of reflection data.

\section{Age estimates of the proposed drill sites}

Estimates of sedimentation rates for proposed sites were based mostly on the thickness of Holocene sediment recovered in surface cores from nearby locations (Table T1) and were unlikely to accurately represent mean sedimentation rates over long periods of time and, in particular, during cold, glacial periods. Using a range of possible sedimentation rates we expected that the proposed triple-advanced piston coring (APC) would at least penetrate through a significant part of the Pleistocene and that deeper drilling would possibly penetrate to upper Miocene beds at Bowers Ridge (Sites BOW-12B and BOW-14B) and gateway (Sites GAT-4B and GAT-3B) sites on the Beringian margin.

\section{Site explanations and seismic profiles in the Bering Sea}

Ten Bering Sea drilling sites were proposed: seven "highest priority" sites (SHR-1B, BOW-12B, BOW14B, BOW15A, GAT-3C, GAT-4C, and UMK-4D), two "high-priority alternate" sites (SHR-1B and UMK-3B), and one "second priority" site (KST-1B) (Table T1; Fig. F1). Prioritization was provided in response to a request from IODP-SAS-SSEP. Four relatively deep sites were proposed (triple-APC holes to refusal and a single extended core barrel [XCB] hole to 700 meters below seafloor [mbsf]), two on Bowers Ridge (Sites BOW-12B and BOW-14B) and two Bering gateway sites (Sites GAT-4B and GAT-3B). At each of the other sites, triple holes employed APC to refusal $(\sim 200$ mbsf). To achieve all scientific objectives at Bowers Ridge, Site BOW-15A was proposed during the late stage.

The basic drilling strategy was to recover the paleoclimatic, paleoenvironmental, and paleoceanographic record archived in Bering Sea sediment, as well as to achieve good horizontal coverage about surface and deepwater conditions needed to reconstruct water column gradients. Proposed drilling sites were located between 837 and 3891 meters below sea level (mbsl) with a range of depth coverage. Based on the results of DSDP Site 188 (2649 mbsf) on Bowers Ridge (Echols, 1973) and site survey Cruise KH99-3 piston cores (Yasuda and Sagawa, 2003; Asahi and Takahashi, 2003), good carbonate and foraminifer assemblage preservation was expected.

\section{Bowers Ridge}

Bowers Ridge is topographically and structurally linked to the Aleutian Island arc. Bowers Ridge extends northward from the ridge of the Aleutian Island arc to curve westward and subparallel to the trend of the Aleutian Ridge. The summit of Bowers Ridge is generally flat-topped and deeper than $1000 \mathrm{~m}$. Sediment cores from Bowers Ridge were intended to provide records from the shallowest part of our vertical depth transect to slightly deeper depth, and, when compared to Umnak Plateau and Beringian margin sites, would be used to evaluate vertical water mass gradients. Sediment cores from Bowers Ridge would also serve to represent the southernmost part of the Bering Sea when compared to other, more northerly, proposed sites. Good foraminifer preservation, as found at DSDP Site 188 on Bowers Ridge at $2649 \mathrm{~m}$ depth (Echols, 1973), was expected at Bowers Ridge sites. Based on the results of Leg 19, it was anticipated that drilling to a subsurface depth of $\sim 700 \mathrm{~m}$ would recover diatomaceous sediments for the entire Pleistocene and Pliocene and perhaps mudstone from the late Miocene (Scholl and Creager, 1973).

The site survey data at Bowers Ridge were obtained in 1999 on Cruise KH99-3 of the Hakuhou-maru (Fig. F3). In their last communication, EPSP requested (1) annotation of the seismic data to reflect crossings and inclusion of shotpoints on the track lines shown on the bathymetric map; (2) relocation of the site to the line crossing; and (3) provision of a map of multibeam bathymetry used to construct the bathymetric map. To comply, we reprocessed the original site survey data of Cruise KH99-03. We updated and corrected a series of sets of navigation data, swath map bathymetry, $3.5 \mathrm{kHz}$ subbottom profiles, and MCS reflection profiles. We used updated shotpoint numbers for seismic profiles corrected against rechecked navigation data. Shotpoint numbers assigned in the descriptions below were systematically corrected from the initial submitted version of data and profiles. Water depth at each of the sites was estimated using multibeam bathymetry (SeaBeam $2120 H R)$. Seismic velocity analysis was also performed to assess the presence of gas hydrate.

\section{Site BOW-12B (U1340)}

The location of Site BOW-12B (Figs. F4, F5, F6, F7; Table T1) was positioned at time $0602 \mathrm{~h}$, Shotpoint 5863, on Line Stk6-1 (Figs. F8, F9) and time 0942 h, Shotpoint 1537, on Line Stk6-3 (Figs. F10, F11). For the initial proposed site, we tried to locate the site on the seismic crossing point, responding to the recommendation of EPSP to do so, where it seemed to pres- 
ent no problem for drilling on swath bathymetry (Fig. F5) and subbottom profiles (Fig. F6). However, on seismic Line Stk6-1, the crossing point was located at a small mound on the seafloor (which appears to be a mud volcano), and the upper sediments between 1.75 and 2.0 two-way traveltime (TWT) seemed to be of condensed stratification, slightly disturbed in the eastern part. For these reasons, we moved the site slightly from the crossing point to Shotpoint 910 on Line Stk6-1, where sediments appear to be well stratified in the deeper sedimentary section below the proposed site (Figs. F8, F9).

Water depth was estimated at $1313 \mathrm{~m}$ by multibeam bathymetry (Fig. F5). A penetration depth of 700 meters below seafloor (mbsf) was proposed and approved by EPSP at this site, and we expected recovery of a continuous sedimentary section accumulating since the late Miocene. However, because wavy and weak seismic reflections were recognized in the upper sequence of the processed seismic reflection horizons at Site BOW-12B (Figs. F9, F11), it seemed likely that a continuous Quaternary section might be difficult to recover. No obvious bottom-simulating reflector (BSR) was recognized at this site (Figs. F8, F10). Seismic velocity analysis around the site indicated that $P$-wave velocity increases gradually with depth, implying the absence of methane gas hydrate (Fig. F12).

\section{Site BOW-14B (U1341)}

The location of Site BOW-14B (Figs. F13, F14, F15; Table T1) was positioned on the crosssing point of the seismic survey lines at time $1045 \mathrm{~h}$, Shotpoint 650, of Line Stk5-1 (Fig. F16) and time 1825 h, Shotpoint 2488, on Line Stk5-5 (Fig. F17). The sedimentary section appeared to be well stratified at the crossing point (Figs. F18, F19, F20). A penetration depth of 700 mbsf was proposed at this site, expecting recovery of a continuous sedimentary section building since the late Miocene at a deeper water depth (2166 mbsl) than at Site BOW-12B (1313 mbsl). Prominent BSRs are observed on Line Stk5-5 at $\sim 3.5-3.8 \mathrm{~s}$ TWT, which was estimated to be at 750-850 mbsf (Figs. F18, F19, F20, F21). A low-velocity zone was detected immediately beneath the BSR (Fig. F12), suggesting the presence of free gas immediately below interstitial deposits of methane gas hydrate. For this reason, penetration depth at this site was modified by EPSP to 600 mbsf.

\section{Site BOW-15A (U1342)}

Site BOW-15A (Figs. F22, F23, F24; Table T1) was located at the well-stratified location at Shotpoint 410 on Line Stk4-1 (Fig. F25) because of weak and wavy seismic reflections between Shotpoints 450 and 550 on Line Stk4-1 (Fig. F25), which is north of seismic crossing point at time $1620 \mathrm{~h}$, Shotpoint 505, on Line Stk4-1 and time 1921 h, Shotpoint 1203, on Line Stk4-3 (Fig. F26). Based on seismic data, Site BOW-15A was added in order to achieve the proposed science objectives of Bowers Ridge drilling to recover a continuous and complete Quaternary record because wavy and weak seismic reflections were recognized in the upper sequence of the reprocessed seismic reflection at both Sites BOW-12B and BOW14B. A penetration depth of $165 \mathrm{mbsf}$ at Site BOW$15 \mathrm{~A}$ by multi-APC coring was approved by EPSP, which was deemed necessary to recover the Quaternary sedimentary sequence covering the much older basement core of Bowers Ridge.

\section{Bering/Arctic gateway}

The continental slope or Beringian margin bordering the north side of the Aleutian Basin represents a gateway to the Arctic Ocean through the Bering Strait farther to the north. Sediments needed to reconstruct the evolution of gateway oceanography and climate can be readily recovered along the Beringian margin. Stratigraphic changes in sediment $\mathrm{CaCO}_{3}$ and opal content ought to reveal the exchange history of Pacific-Atlantic water masses. Pollen analysis will help decipher the temporal variability of continental environments to the west and east. Studies of ice-rafted lithic debris as well as ice algae will disclose the history of glaciation as well as sea ice formation. Sediment trap data collected close to Beringian gateway sites provide ground-truthing information needed to reconstruct paleoceanographic surface water conditions near the Bering Strait based on diatoms and coccolithophores (e.g., Coccolithus pelagicus, a cold-water taxon that occurs in high abundances at the trap stations, and its ancestors). The late Miocene/Pliocene boundary was placed at $\sim 400 \mathrm{mbsf}$ at DSDP Site 190 (water depth = $3875 \mathrm{mbsl}$ ) in the abyssal floor of the western Aleutian Basin (Koizumi, 1973) and the bottom age of the hole at $627 \mathrm{mbsf}$ in the middle Miocene. Thus, we can reasonably anticipate that by drilling to 700 mbsf along the gateway margin much of the Pliocene-Pleistocene-Holocene sequence, if not some of the upper Miocene, would be recovered. Owing to scanty recovery by DSDP using the bit rotation technology available in the early 1970s, we do not know whether hiatuses existed at Site 190, although it is probable that we have a continuous section here of mixed turbiditic and diatomaceous deposits. After the 1999 site survey Cruise KH99-3 of the Hakuhou-maru and discussion with EPSP, gateway margin drilling sites (GAT-3C and GAT-4C) were selected in areas topographically protected from turbi- 
dite deposition (Fig. F27). We also prioritized a relatively shallow site (GAT-3C) to optimize the chances for good carbonate preservation and another (Site GAT-4C) at deeper depths for water chemistry comparison.

\section{Site GAT-3C (U1344)}

Site GAT-3C (Figs. F28, F29, F30; Table T1) was placed at Shotpoint 2860 on seismic Line Stk3-7 (Figs. F31, F32) near the crossing points of seismic Line Stk3-7 and Line Stk3-5 (Figs. F33, F34). A penetration depth of 700 mbsf at Site GAT-3C was approved by EPSP.

Based on detailed navigation information and seismic profiles (Figs. F28, F32, F34), a prominent BSR on Line Stk3-5 was not recognized below Site GAT3C. A low-velocity zone was not detected beneath the interval of increased velocity (Fig. F35), suggesting the absence of methane gas hydrate at Site GAT-3C.

\section{Site GAT-4C (U1343)}

Site GAT-4C (Figs. F36, F37, F38; Table T1) was positioned at Shotpoint 351 on Line Stk1 (Figs. F39, F40) near the crossing point with seismic Line Stk1 and on Line Stk2 (Figs. F41, F42). The selection of the approximate crosssing point was made because at the crossing point irregular reflections were recognized around the BSRs. A penetration depth of $700 \mathrm{mbsf}$ was approved by EPSP.

Obvious BSRs were recognized on Lines Stk1 and Stk2 at a subsurface depth of $1.0 \mathrm{~s}$ TWT (Fig. F43). A low-velocity zone was not detected immediately beneath the BSRs, suggesting the absence of interstitial gas around Site GAT-4C (Fig. F35).

\section{Umnak Plateau}

Umnak Plateau is located north of Umnak Island in the eastern corner of the deepwater Bering Sea Basin (Fig. F1). Parts of the Alaskan Stream flow into the Bering Sea through Umnak and Amukta Passes and over the plateau. Sediments on Umnak Plateau can be studied to monitor the exchange of Pacific and Bering Sea waters. These passes are fairly shallow ( $\sim 50$ and $430 \mathrm{mbsl}$ ), so intermediate or deep water cannot flow out through them to the Pacific. On Umnak Plateau at DSDP Sites 184 and 185, Scholl and Creager (1973) reported Pleistocene diatomaceous sediments with ash layers in the top $120 \mathrm{mbsf}$ overlying Pliocene diatomaceous sediments. Sedimentation rates are $\sim 67 \mathrm{~m} / \mathrm{m}$.y. The ash layers also indicate that diatomaceous sediments have neritic components, probably influenced from the Bristol Bay region immediately to the east. Thus, we antici- pated recovering Pleistocene and Pliocene diatomaceous sediments in the $200 \mathrm{~m}$ of APC cores proposed to be recovered at Umnak Plateau to monitor surface water exchange from the Pacific into the Bering Sea as well as surface conditions in the eastern most region of the Bering Sea Basin.

MCS site survey data were provided by USGS Cruise L6-80 of the Lee (1980), later augmented in 1999 by multibeam bathymetry and $3.5 \mathrm{kHz}$ subbottom profile data collected on Cruise KH99-3 of the Hakuhoumaru.

\section{Sites UMK-4D (U1339) and UMK-3B}

Site UMK-4D, a highest priority site, and Site UMK3B (not drilled during Expedition 323), an alternate site, were positioned by combining site surveys of two cruises (Table T1). The sites were originally proposed to be positioned along MCS seismic Profiles 2, 5 , and 6 of USGS Cruise L6-80 of the Lee (Fig. F44), which were the original digital data recorded along these lines but only digitized seismic images of paper prints of velocity processed and stacked 24-channel data. Navigation and bathymetry maps for USGS Cruise L6-80 of the Lee and Cruise KH99-03 of the Hakuhou-maru were created with Global Mapping Tool (GMT) software (Wessel and Smith, 1995) using Global Topo Data of the Geographic Information Network of Alaska (GINA) (www.gina.alaska.edu/); the maps are shown, respectively, in Figures F44 and F45. A single line of swath bathymetric data and 3.5 $\mathrm{kHz}$ subbottom profile was collected during Cruise KH99-03 and used to estimate 1885 mbsl water depth at Site UMK-4D and 1898 mbsl water depth at Site UMK-3B (Figs. F46, F47).

Site UMK-4D is at the point of seismic Lines 2 (Shotpoint 3275) near the crossing point of Lines 2 (Shotpoint 3312) and 5 (Shotpoint 625) of USGS Cruise L6-80 of the Lee (Figs. F44, F48, F49, F50; Table T1). Site UMK-3B is at the crossing point of Lines 2 (Shotpoint 2617) and 6 (Shotpoint 721) of the same cruise of the Lee (Figs. F44, F48, F51, F52; Table T1).

EPSP requested that the annotated BSR on these seismic lines should be confirmed as either a methane gas hydrate or silica transition BSR. The depth of the BSR was estimated at 550-650 mbsf (Fig. F53). A lowvelocity zone was detected beneath the BSR at proposed Site UMK-3B on Line 6 (Fig. F54). DSDP drilling at Umnak Plateau found a prominent silica transition BSR at both Sites 184 and 185. A prominent velocity increase, from $\sim 1.65 \mathrm{~km} / \mathrm{s}$ above to $2.2 \mathrm{~km} / \mathrm{s}$ below the BSR was also measured on recovered cores (Fig. F55). The proposed depth of penetration of the sites was only 200 mbsf, well above the BSR at 550650 mbsf. 


\section{Shirshov Ridge}

Shirshov Ridge extends south from the Siberian continent, forming a shallow topographic ridge separating the Aleutian and Kamchatka Basins, the latter commonly referred to as the Komandorsky Basins.

\section{Sites SHR-3B and SHR-1B}

The site survey data for Sites SHR-3B and SHR-1B (not drilled during Expedition 323) were collected in 1970 during Cruise 02 of the USNS Bartlett (Fig. F56). Although the proposed sites were picked along seismic lines, calculation of the their positions was based on hand-written navigation information. Swath bathymetry and high-resolution subbottom profiles are not available for these sites. Navigation maps were produced using digital trackline data archived and maintained on line by the USGS (Figs. F56, F57, F58). Survey lines and bathymetry shown on these figures were created using GMT and GINA. We corrected the site position (latitude and longitude) by linear interpolation between navigation times on the seismic line because shot numbers tied to position coordinates are not included in the archived information. The water depth of each site was estimated based on gridded bathymetric data.

The highest priority Site SHR-3B (2232 mbsl; Table T1) was proposed to monitor deepwater masses flowing southward out of the Bering Sea to the Pacific and also surface conditions in the eastern Bering Sea (Figs. F57, F59, F60). Alternate Site SHR-1B (963 mbsl; Table T1) would serve to expand the vertical extent of the subsurface water masses (Figs. F58, F61, F62). Based on known sedimentation rates $(8.0 \mathrm{~cm} / \mathrm{k} . \mathrm{y}$.) in this region (Table T1), drilling to 200 mbsf at both sites should penetrate through the Pleistocene and possibly into the late Pliocene. Timedepth conversion used for the two sites is based on the MCS data gathered by the USGS during Cruise L6-80 of the Lee (Figs. F59, F61). Seismic profiles collected by the USNS Bartlett, Cruise 02, during Legs 54 and 55 document that the upper $200 \mathrm{~m}$ of the sedimentary sequences at both of the proposed sites would be well-stratified and safe locations for drilling (Figs. F60, F62).

\section{Kamchatka Strait}

The Kamchatka Strait site was located to monitor deepwater masses exiting southward from Kamchatka Basin through Kamchatka Strait or Kamchatka Pass to the Pacific Basin. The sill depth of the pass is $\sim 4200 \mathrm{~m}$. Mammerickx (1985) presented the possibility that exiting deep waters driven by ther- mohaline circulation within the Bering Sea Basin deposited the Meiji sediment tongue that overlies the northwest corner of the Pacific Basin (Ewing et al., 1968). This large sediment body is similar to North Atlantic Drifts, especially in general shape, length, stratigraphic fabric, and thickness (Scholl et al., 1977, 2003). Drilling at the Kamchatka Strait would help test the Mammerickx hypothesis of thermohaline-driven circulation within the Bering Sea. Much of the sediments in the Meiji Drift body have been supplied from the Bering Sea through the Kamchatka Strait (Scholl et al., 2003; VanLaningham et al., 2009). The proposed site represents one of the deepest of our vertical depth transect and the site closest to the outflow of water from the Bering Sea into the North Pacific.

\section{Site KST-1B}

Only a single-channel seismic profile for proposed Site KST-1B (not drilled during Expedition 323) was collected in 1970 during Cruise 02 of the USNS Bartlett (Fig. F63). Survey lines and bathymetry shown on these figures were created using GMT and GINA because swath bathymetry and high-resolution subbottom profiles are not available for this site. The site position (latitude and longitude) was corrected in the same manner for proposed Sites SHR-3B and SHR-1B (see above).

Site KST-1B (alternate site) is located inside Kamchatka Strait at $3435 \mathrm{mbsl}$ at time $0703 \mathrm{~h}$ on the Bartlett seismic line (Fig. F64). The shallow penetration depth of 200 mbsf should not provide a safety concern (Fig. F65).

\section{Acknowledgments}

We thank Dr. David Scholl for reviewing this manuscript and for providing kind and helpful advice since the early stage of the proposal submission. We thank Daniel Quoidbach for digitizing a large number of paper-form seismic surveys stored in the Lamont-Doherty Earth Observatory site survey data bank. We also thank Barry Katz, Bob Bruce, Akito Furutani, Masami Hato, Hans Juvkam-Wold, Susumu Kato, Tadashi Maruyama, Jean Mascle, Toshifumi Matsuoka, Nobuo Morita, Sumito Morita, Bramley Murton, Donald Potts, Jerome Schubert, Craig Shipp, Dieter Strack, Manabu Tanahashi, Toshiki Watanabe, Joel Watkins, and Bill Winters for discussions and improving interpretation of the site survey data set during EPSP meetings in 2005 (Edinburgh and Hawaii meetings). We thank all crews of Cruise KH99-03 (Hakuhou-maru). 


\section{References}

Asahi, H., and Takahashi, K., 2003. Multivariate analysis on planktonic foraminifera from the Bering Sea: comparison between the modern and the past assemblages. Kaiyo Monthly, 35(6):420-428. (in Japanese)

Creager, J.S., Scholl, D.W., et al., 1973. Init. Repts. DSDP, 19: Washington (U.S. Govt. Printing Office). doi:10.2973/ dsdp.proc.19.1973

Echols, R.J., 1973. Foraminifera, Leg 19, Deep Sea Drilling Project. In Creager, J.S., Scholl, D.W., et al., Init. Repts. DSDP, 19: Washington, DC (U.S. Govt. Printing Office), 721-735. doi:10.2973/dsdp.proc.19.123.1973

Ewing, J., Ewing, M., Aitken, T., and Ludwig, W.J., 1968. North Pacific sediment layers measured by seismic profiling. In Knopoff, L., Drake, C.L., and Hart, P.J. (Eds.), The Crust and Upper Mantle of the Pacific Area-Internat. Upper Mantle Proj., Sci. Rept. 15. Geophys. Monogr., 12:147-173.

Koizumi, I., 1973. The late Cenozoic diatoms of Sites 183193, Leg 19 Deep Sea Drilling Project. In Creager, J.S., Scholl, D.W., et al., Init. Repts. DSDP, 19: Washington, DC (U.S. Govt. Printing Office), 805-855. doi:10.2973/ dsdp.proc.19.130.1973

Mammerickx, J., 1985. A deep-sea thermohaline flow path in the northwest Pacific. Mar. Geol., 65(1-2):1-19. doi:10.1016/0025-3227(85)90043-X

Scholl, D.W., and Creager, J.S., 1973. Geologic synthesis of Leg 19 (DSDP) results; far North Pacific, and Aleutian Ridge, and Bering Sea. In Creager, J.S., Scholl, D.W., et al., Init. Repts. DSDP, 19: Washington, DC (U.S. Govt. Printing Office), 897-913. doi:10.2973/ dsdp.proc.19.137.1973
Scholl, D.W., Hein, J.R., Marlow, M., and Buffington, E.C., 1977. Meiji sediment tongue: North Pacific evidence for limited movement between the Pacific and North American plates. Geol. Soc. Am. Bull., 88(11):1567-1576. doi:10.1130/0016-7606(1977)88<1567:MST$\mathrm{NPE}>2.0 . \mathrm{CO} ; 2$

Scholl, D.W., Stevenson, A.J., Noble, M.A., and Rea, D.K., 2003. The Meiji drift body of the northwestern Pacificmodern and paleoceanographic implications. In Prothero, D. (Ed.), From Greenhouse to Icehouse: The Marine Eocene-Oligocene Transition: New York (Columbia Univ. Press).

Takahashi, K., 2005. The Bering Sea and paleoceanography. Deep-Sea Res., Part II, 52(16-18):2080-2091. doi:10.1016/j.dsr2.2005.08.003

VanLaningham, S., Pisias, N.G., Duncan, R.A., and Clift, P.D., 2009. Glacial-interglacial sediment transport to the Meiji Drift, northwest Pacific Ocean: evidence for timing of Beringian outwashing. Earth Planet. Sci. Lett., 277(1-2):64-72. doi:10.1016/j.epsl.2008.09.033

Wessel, P., and Smith, W.H.F., 1995. New version of Generic Mapping Tools released. Eos, Trans. Am. Geophys. Union, 76(33):329. doi:10.1029/95E000198

Yasuda, H., and Sagawa, Y., 2003. Paleoceanographic changes of intermediate and deep waters in the Being Sea based on benthic foraminifera. Kaiyo Monthly, 25(6):387-393. (in Japanese)

Initial receipt: 4 October 2010

Acceptance: 23 November 2010

Publication: 15 March 2011

MS 323-111 
Figure F1. Overview map of proposed sites in the Bering Sea, Expedition 323. Bathymetry image and contour line created by Global Mapping Tool (Wessel and Smith, 1995) using NGDC/NOAA ETOPO2 database (www.ngdc.noaa.gov/mgg/fliers/01 mgg04.html). Solid line contours = $1000 \mathrm{~m}$. DSDP = Deep Sea Drilling Project, ODP = Ocean Drilling Program.

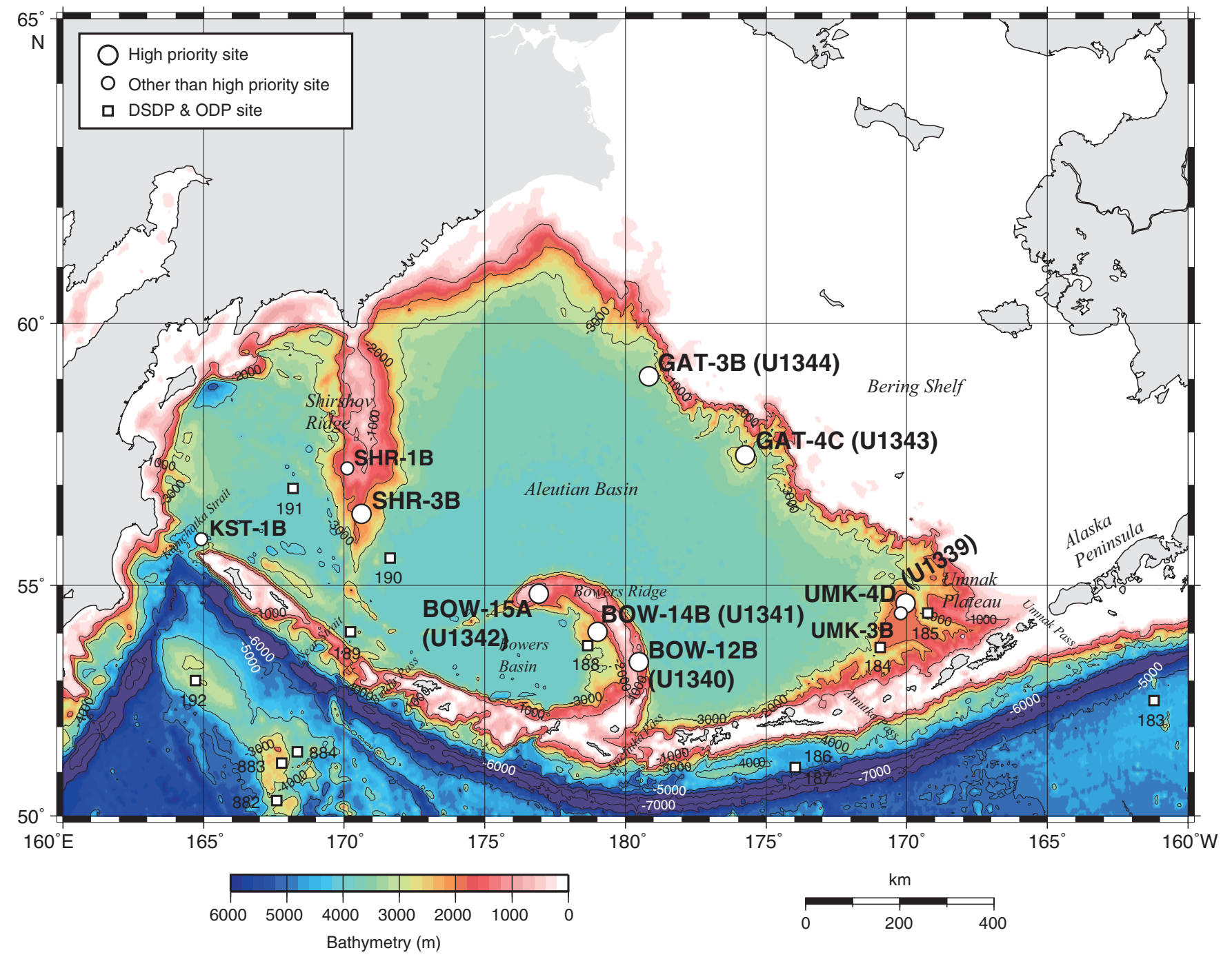


Figure F2. Overview navigation map in the Bering Sea, Expedition 323. Close-up maps of navigation are shown in Figures F3, F27, and F55.

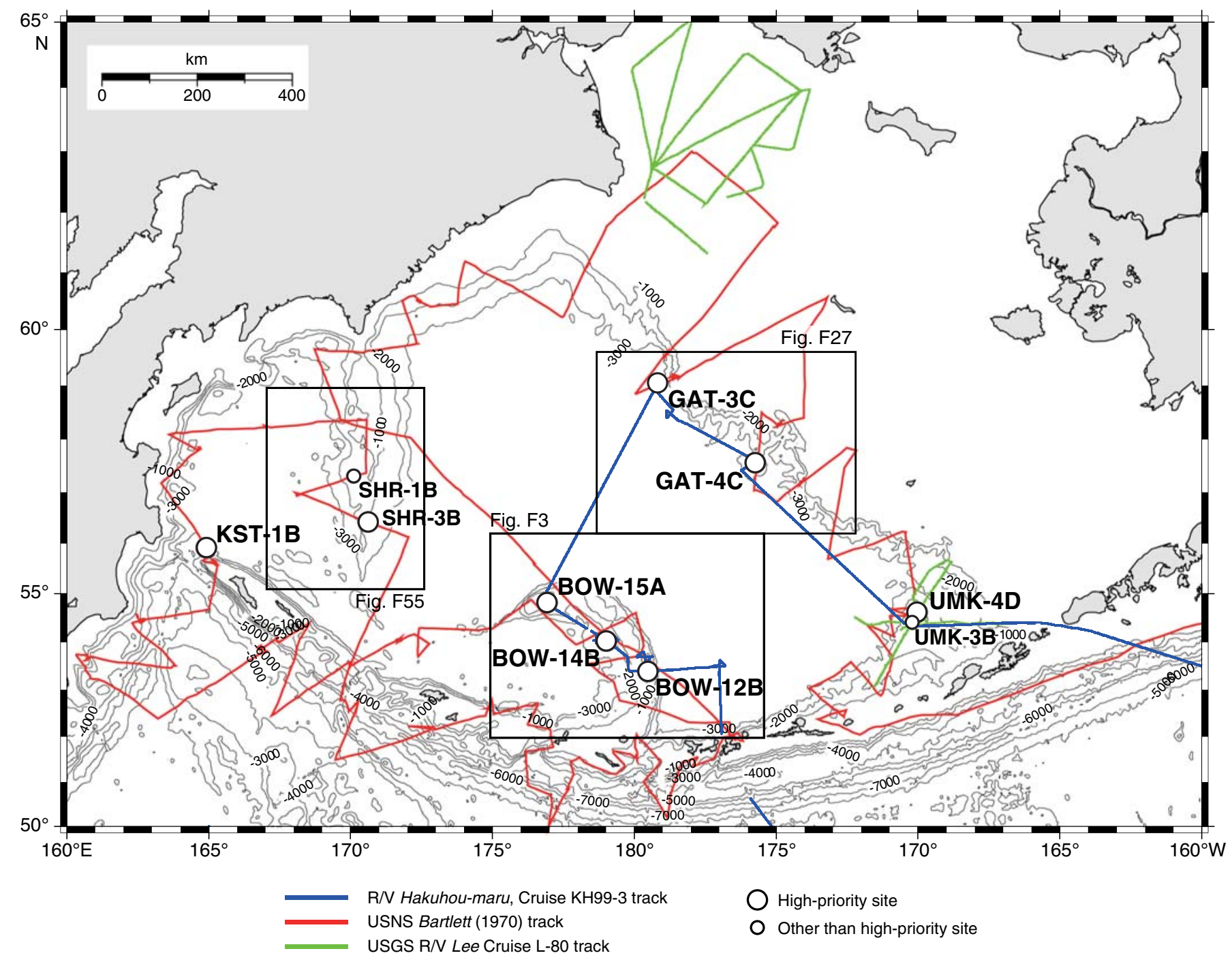


Figure F3. Regional overview map of Bowers Ridge sites, Expedition 323. Close-up maps of navigation are shown in Figures F4, F13, and F22.

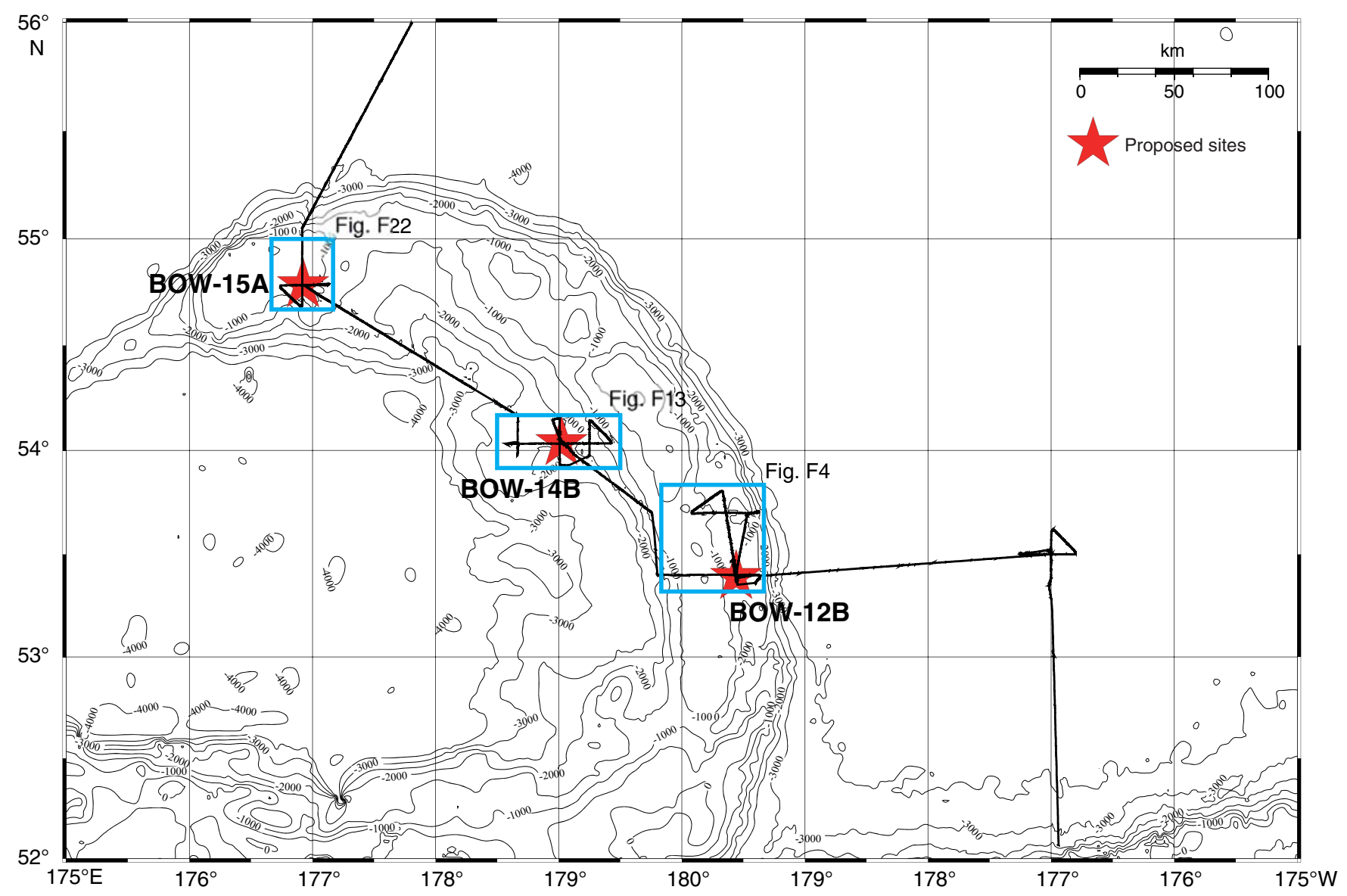


Figure F4. Specific navigation map of Cruise KH99-03, Site BOW-12B. Survey line crossing at 06:02:15 h, Shotpoint 863, Line Stk6-1 (west-east) and 09:42:05 h, Shotpoint 1537, Line Stk6-3 (south-north). Site BOW-12B is at 06:13:20 h, Shotpoint 910, Line Stk6-1 (west-east). Close-up navigation shown in Figure F7.

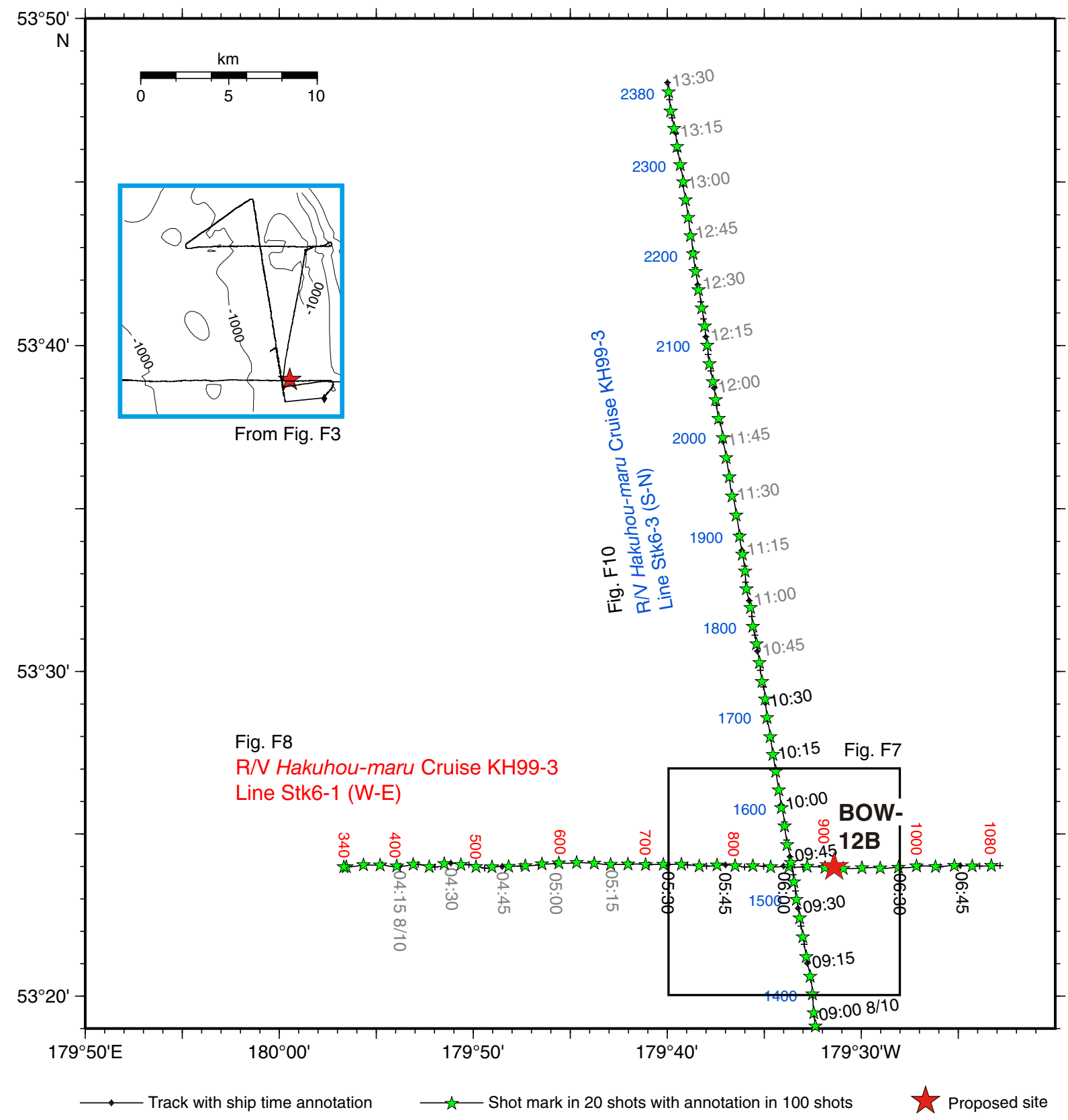


Figure F5. (A) Plain and (B) shaded relief swath bathymetric map of Cruise KH99-03, Site BOW-12B.

A

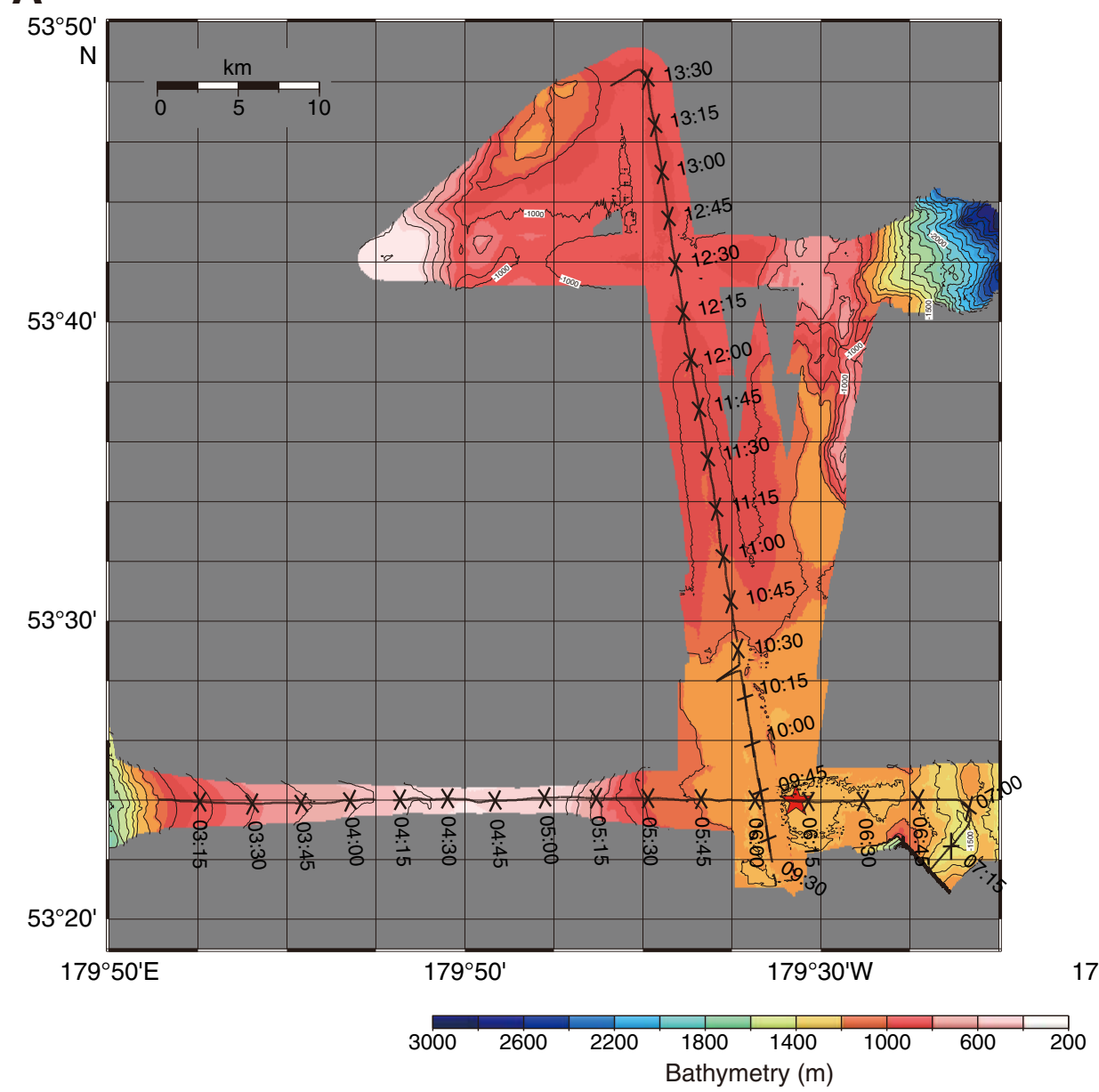

B

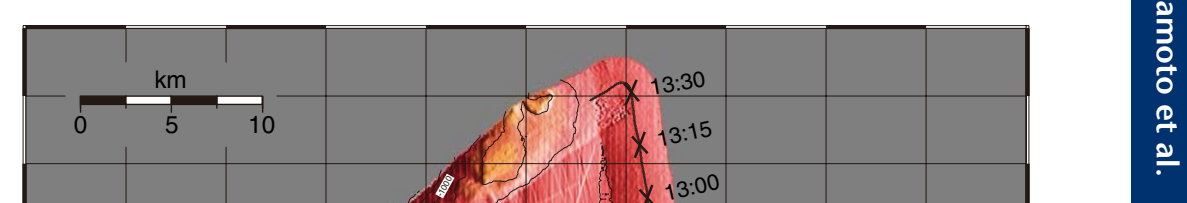

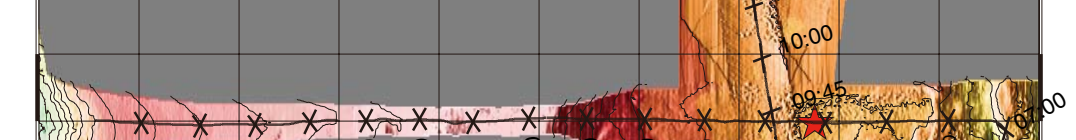

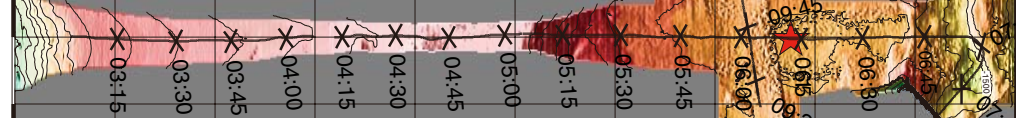

$79^{\circ} 50^{\prime} \mathrm{E}$

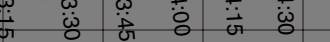

1.9 .30 
Figure F6. $3.5 \mathrm{kHz}$ subbottom profiles from Cruise KH99-03, Site BOW-12B. A. Line Stk6-1 (west-east). B. Line Stk6-3 (south-north).
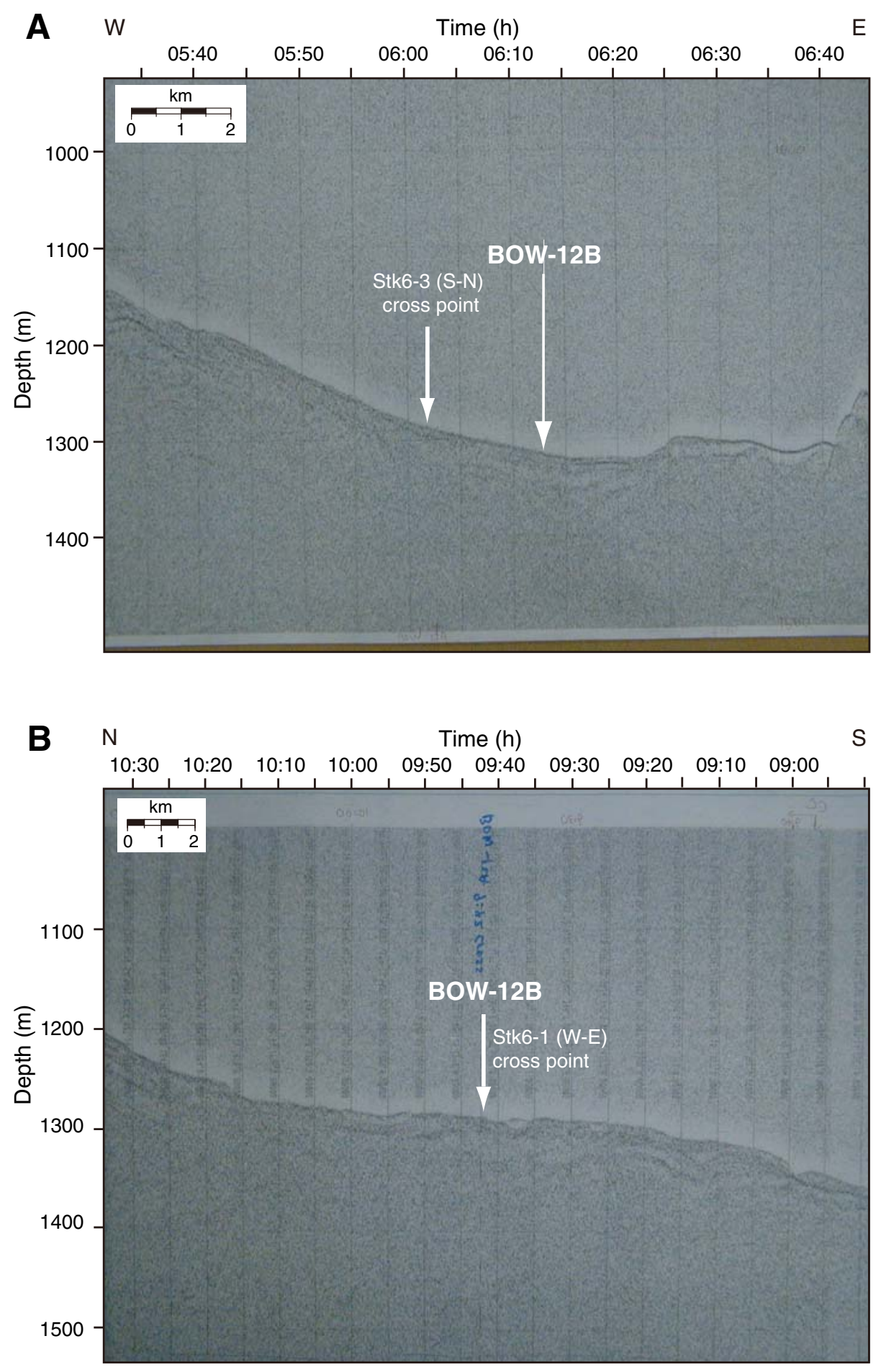
Figure F7. Close-up navigation map of Cruise KH99-03, Site BOW-12B.

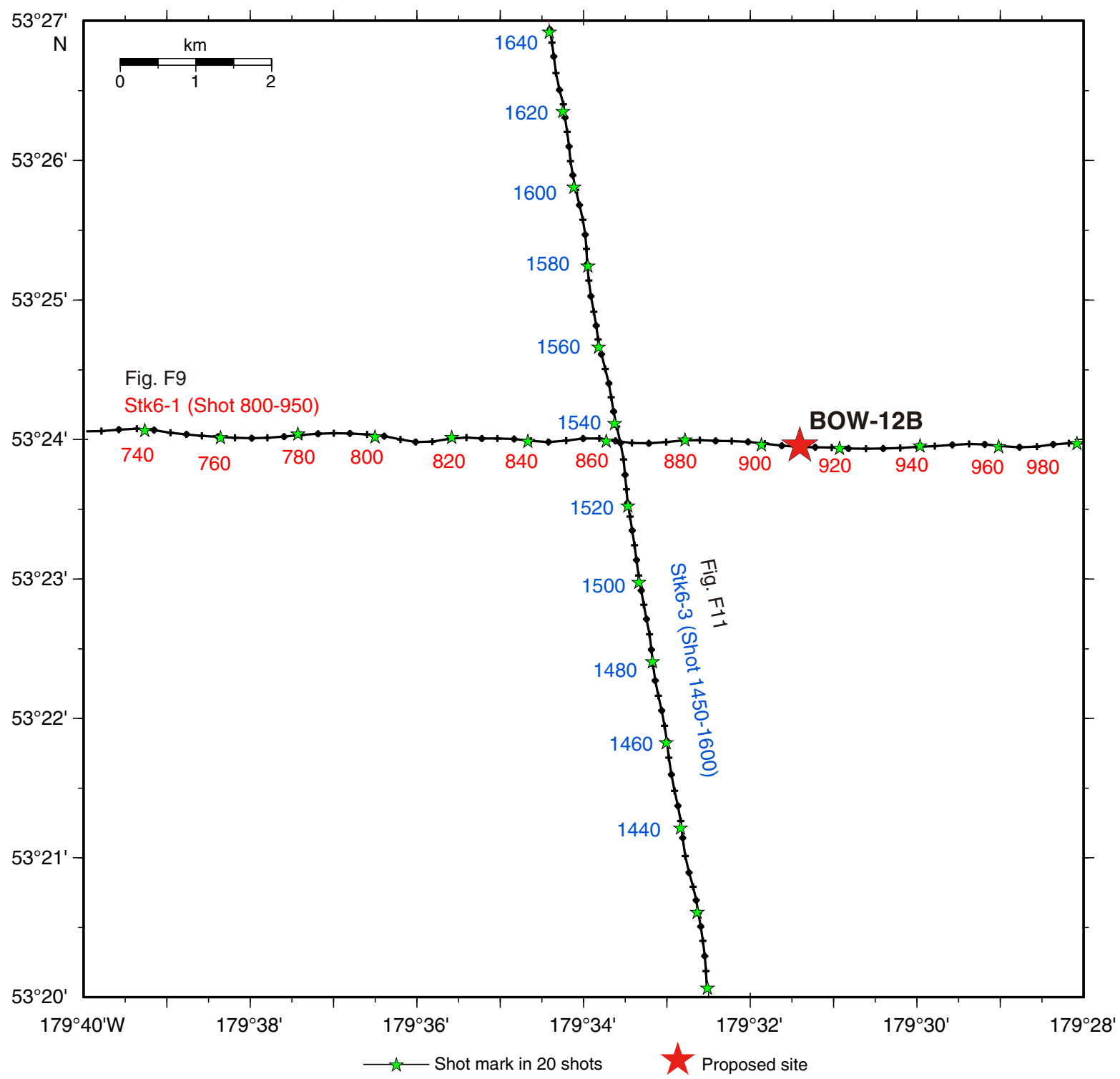


Figure F8. Seismic profile for Line Stk6-1 (west-east) from Cruise KH99-3, Site BOW-12B $\left(179^{\circ} 31.3^{\prime} \mathrm{W}, 53^{\circ} 24.0^{\prime} \mathrm{N}\right.$, Shotpoint 910 , water depth = $1313 \mathrm{mbsl}$, penetration depth $=700 \mathrm{mbsf})$.

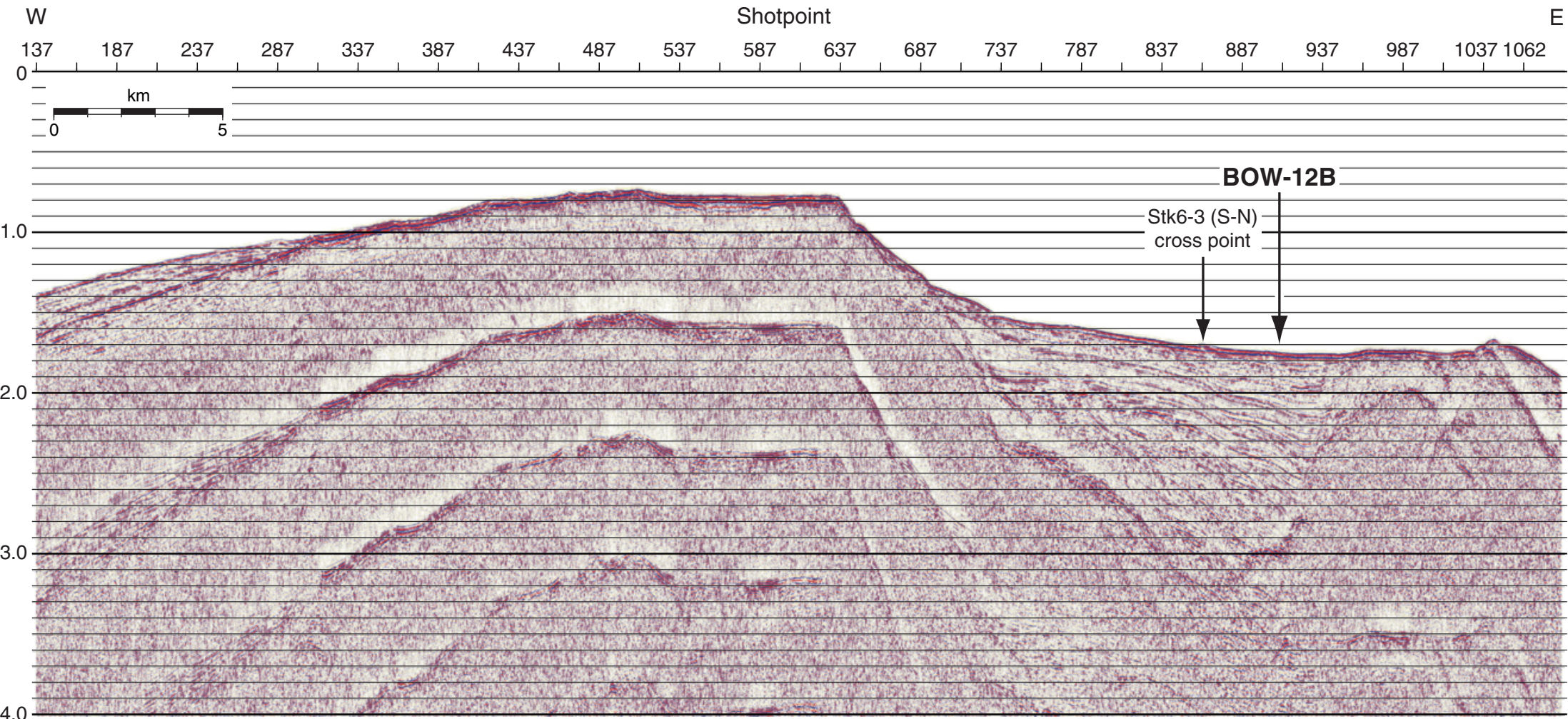


Figure F9. A. Close-up seismic profile for Line Stk6-1 (west-east) from Cruise KH99-3, Site BOW-12B. B. Time-depth curve estimated from results of velocity analyses on Lines Stk6-1 and Stk6-3.

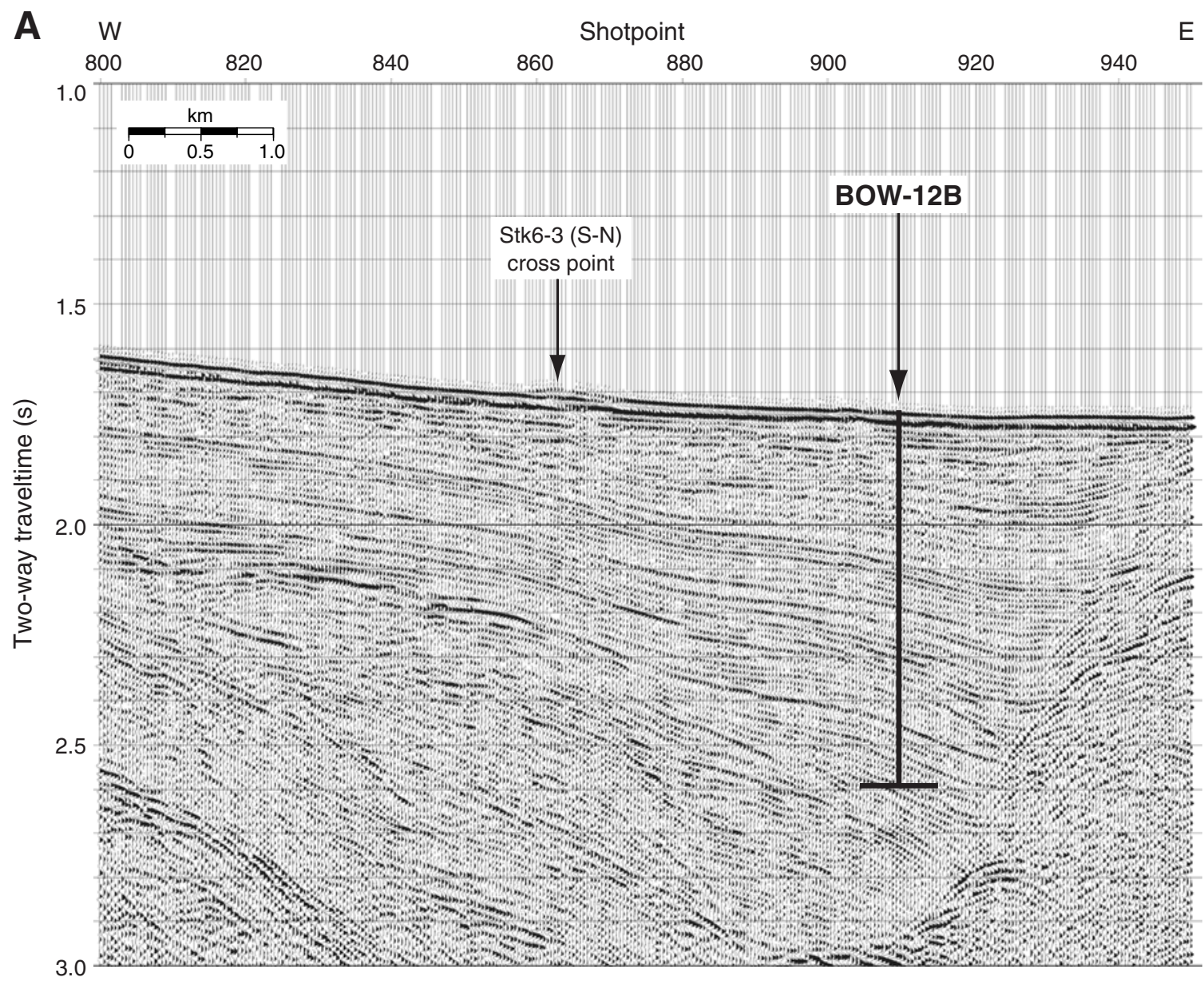

B Two-way traveltime below seafloor (s)

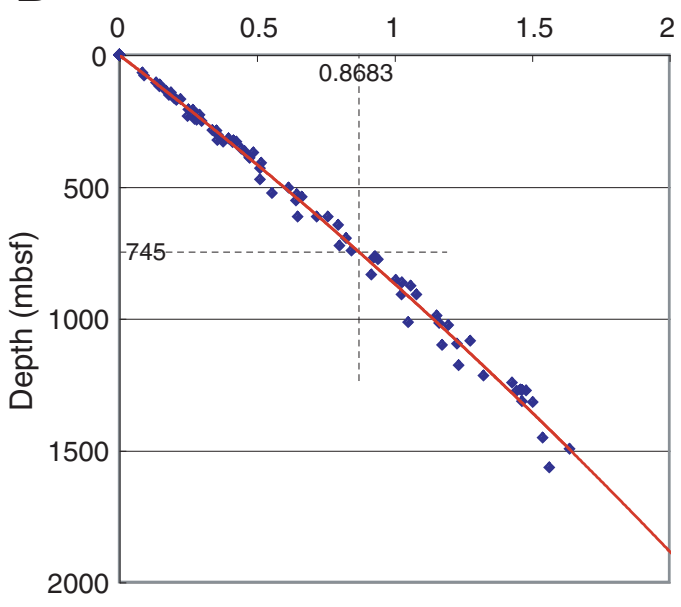


Figure F10. Seismic profile for Line Stk6-3 (south-north) from Cruise KH99-3 projected from the east on the crossing point, Site BOW-12B.

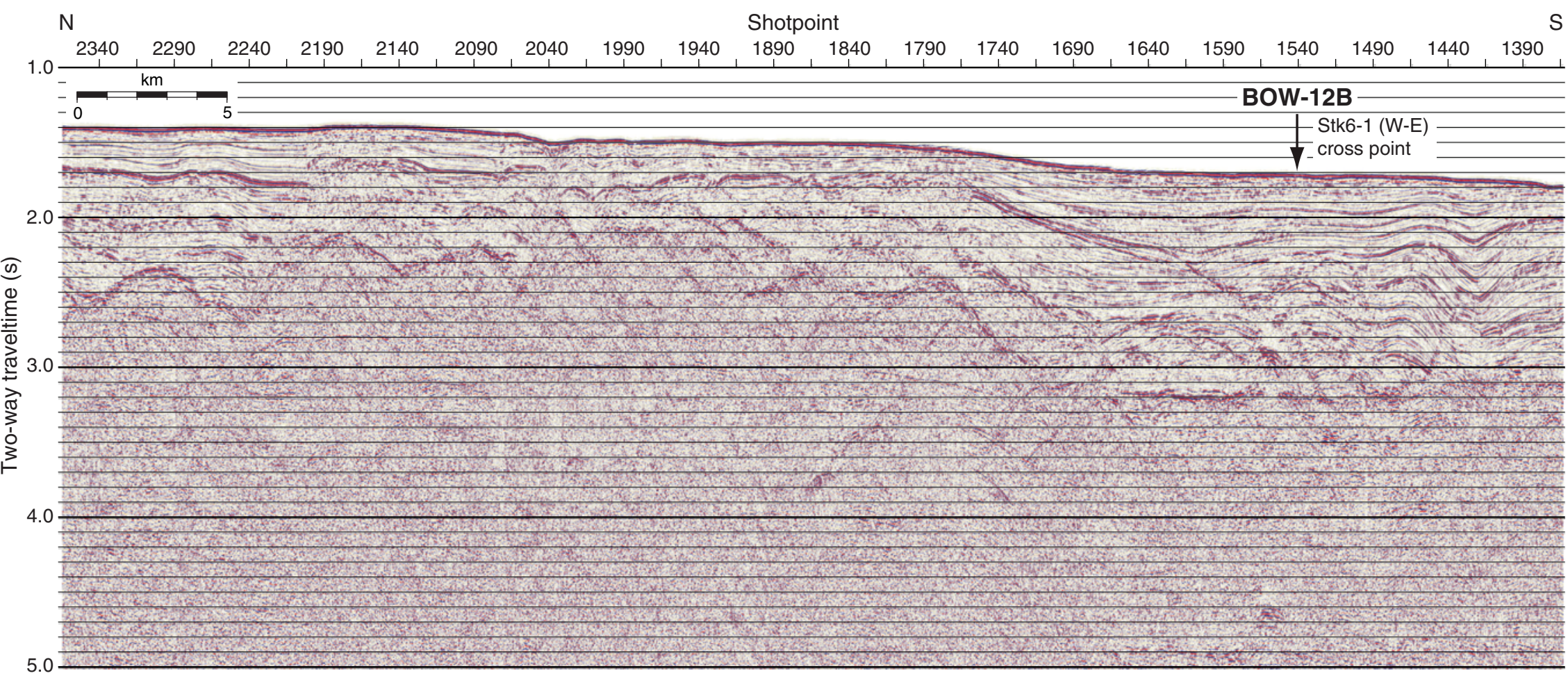


Figure F11. A. Close-up seismic profile for Line Stk6-3 (south-north) from Cruise KH99-3, Site BOW-12B. B. Time-depth curve estimated from results of velocity analyses on Lines Stk6-1 and Stk6-3.
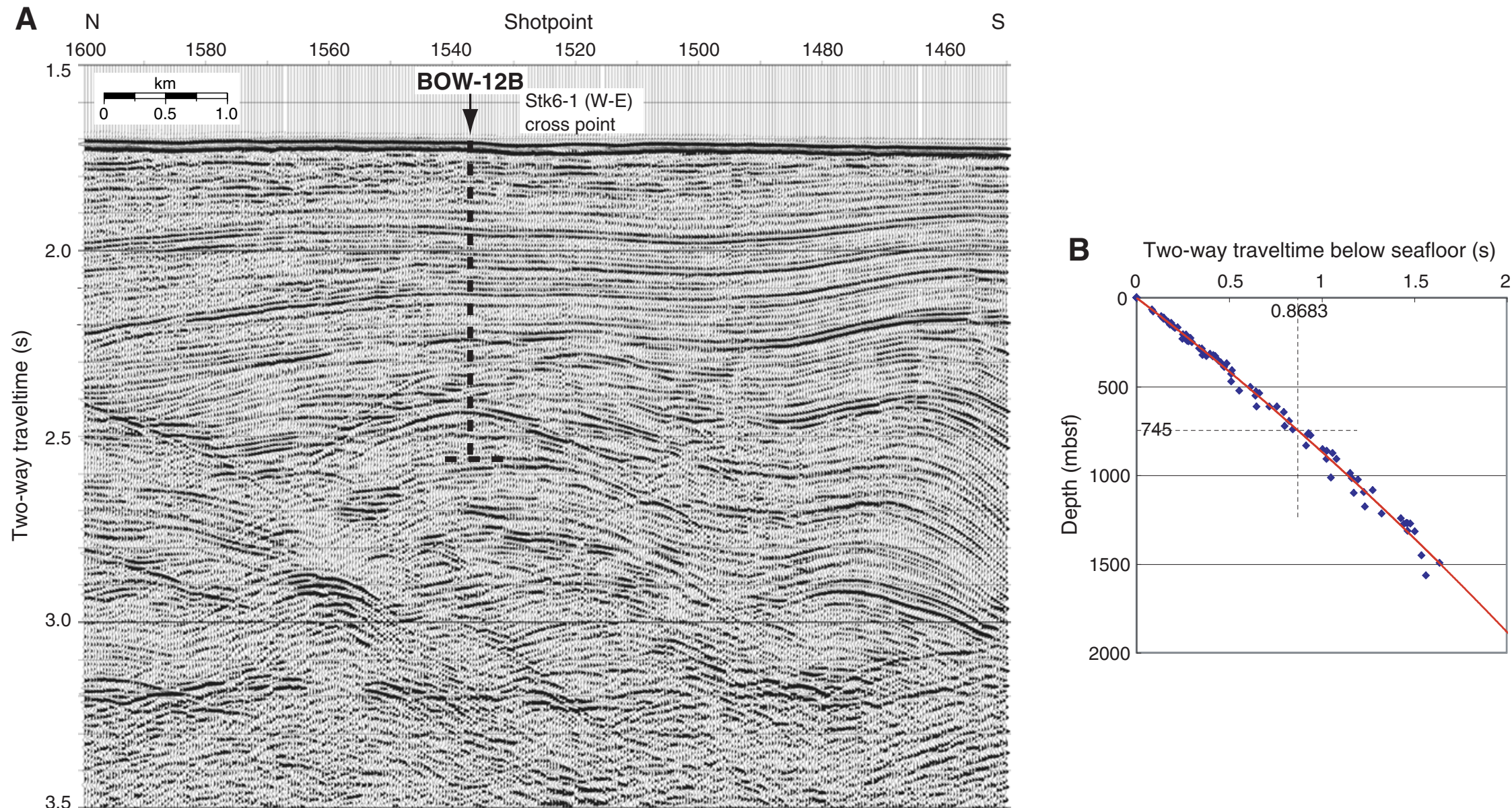
Figure F12. Interval velocity analyses from Cruise KH99-3 for (A) Line Stk6-1 at Site BOW-12B and (B) Line Stk5-5 at Site BOW-14B. A low-velocity zone was detected beneath the bottom-simulating reflector (BSR), suggesting the existence of gas hydrate around Site BOW-14B.

A

A $P$-wave velocity $(\mathrm{m} / \mathrm{s})$

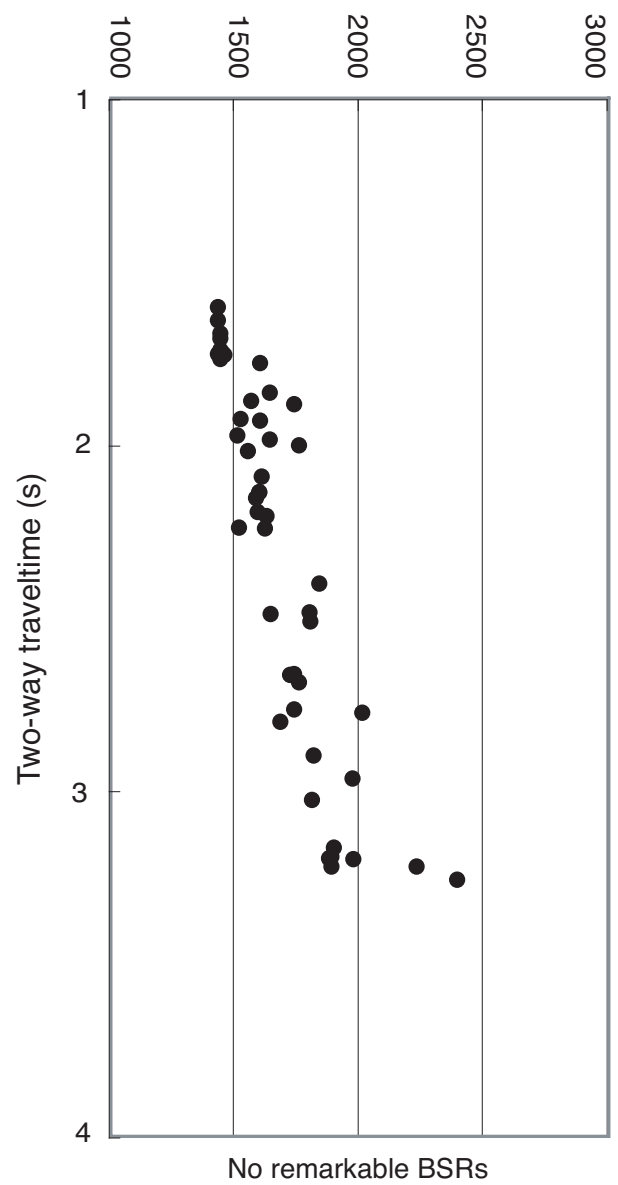

B $P$-wave velocity $(\mathrm{m} / \mathrm{s})$

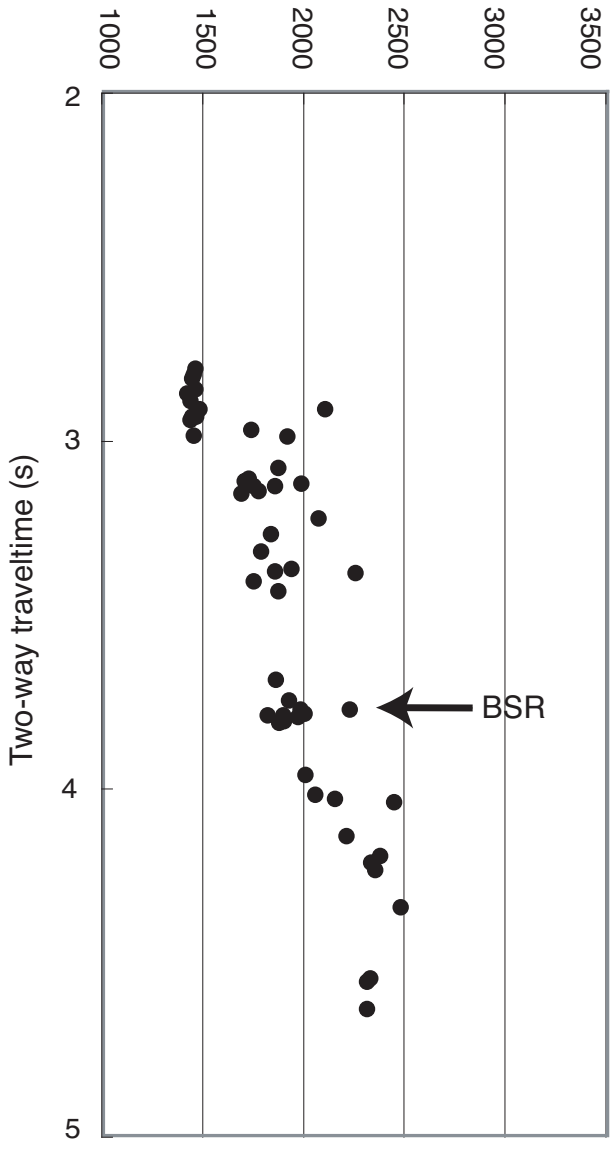


Figure F13. Specific navigation map of Cruise KH99-03, Site BOW-14B. Survey line crossing at 10:45:03 h, Shotpoint 670, Line Stk5-1 (west-east) and 18:25:13 h, Shotpoint 2488, Line Stk5-5 (south-north). Site BOW-12B is at 06:13:20 h, Shotpoint 910, Line Stk6-1 (west-east). Close-up navigation shown in Figure F18.

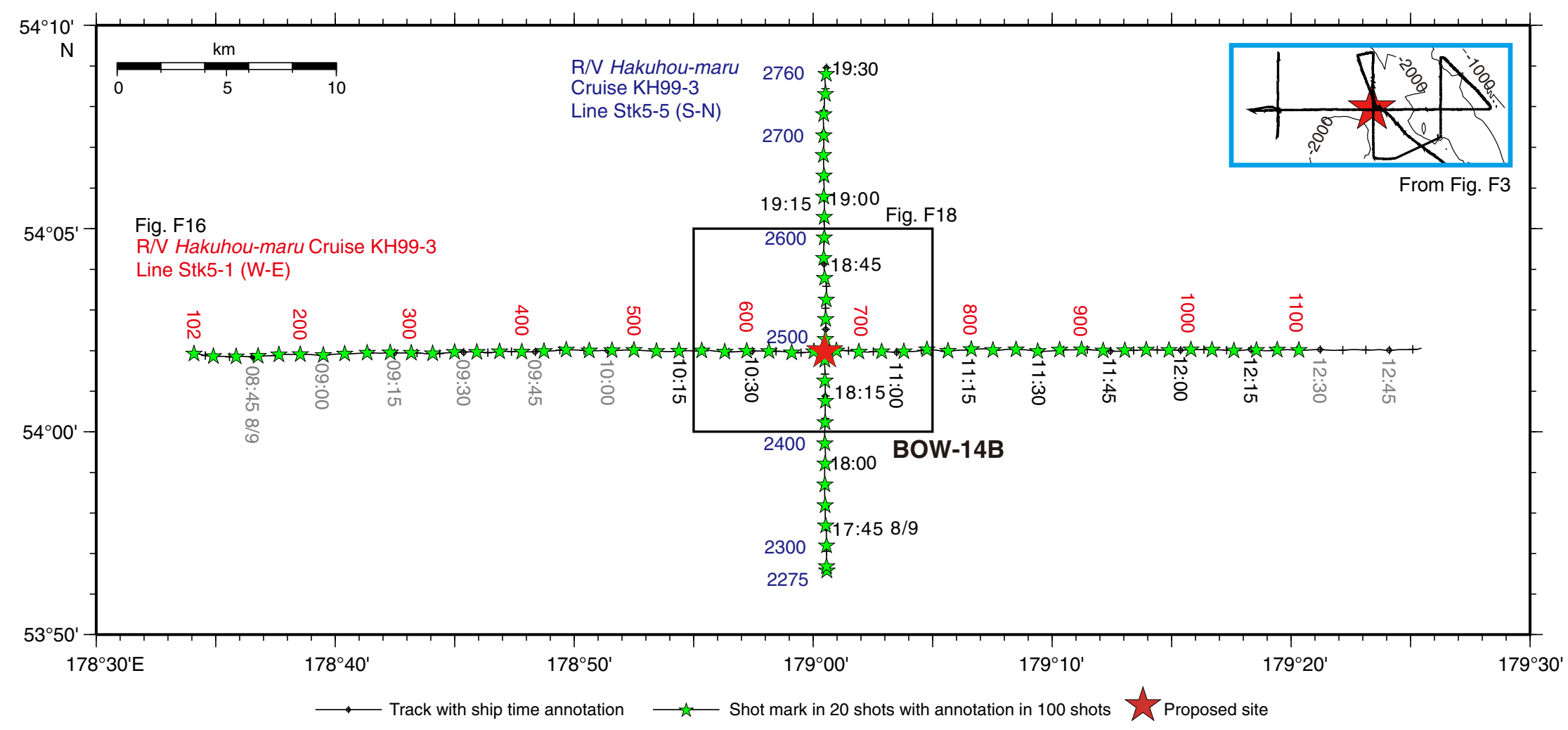


Figure F14. (A) Plain and (B) shaded relief swath bathymetric maps of Cruise KH99-03 for Site BOW-14B.

\section{A}

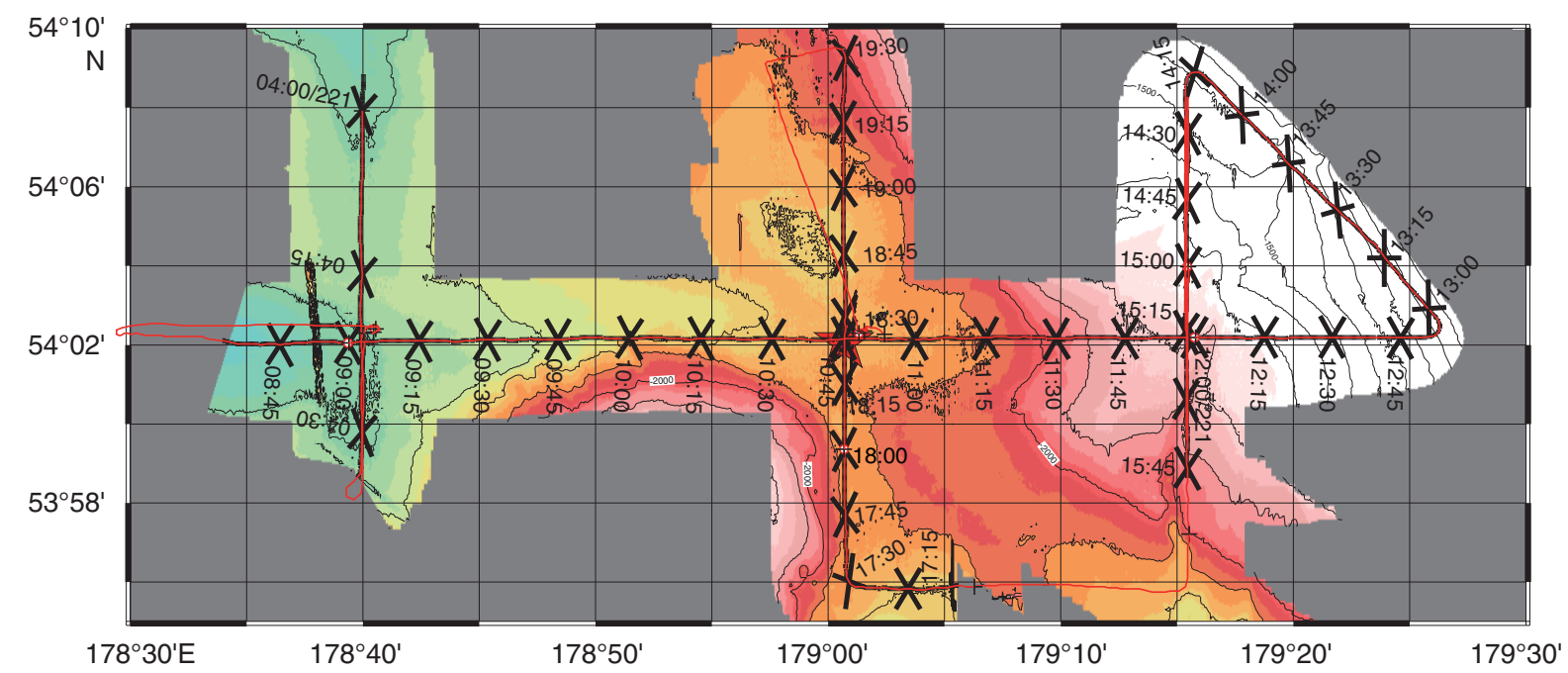

B

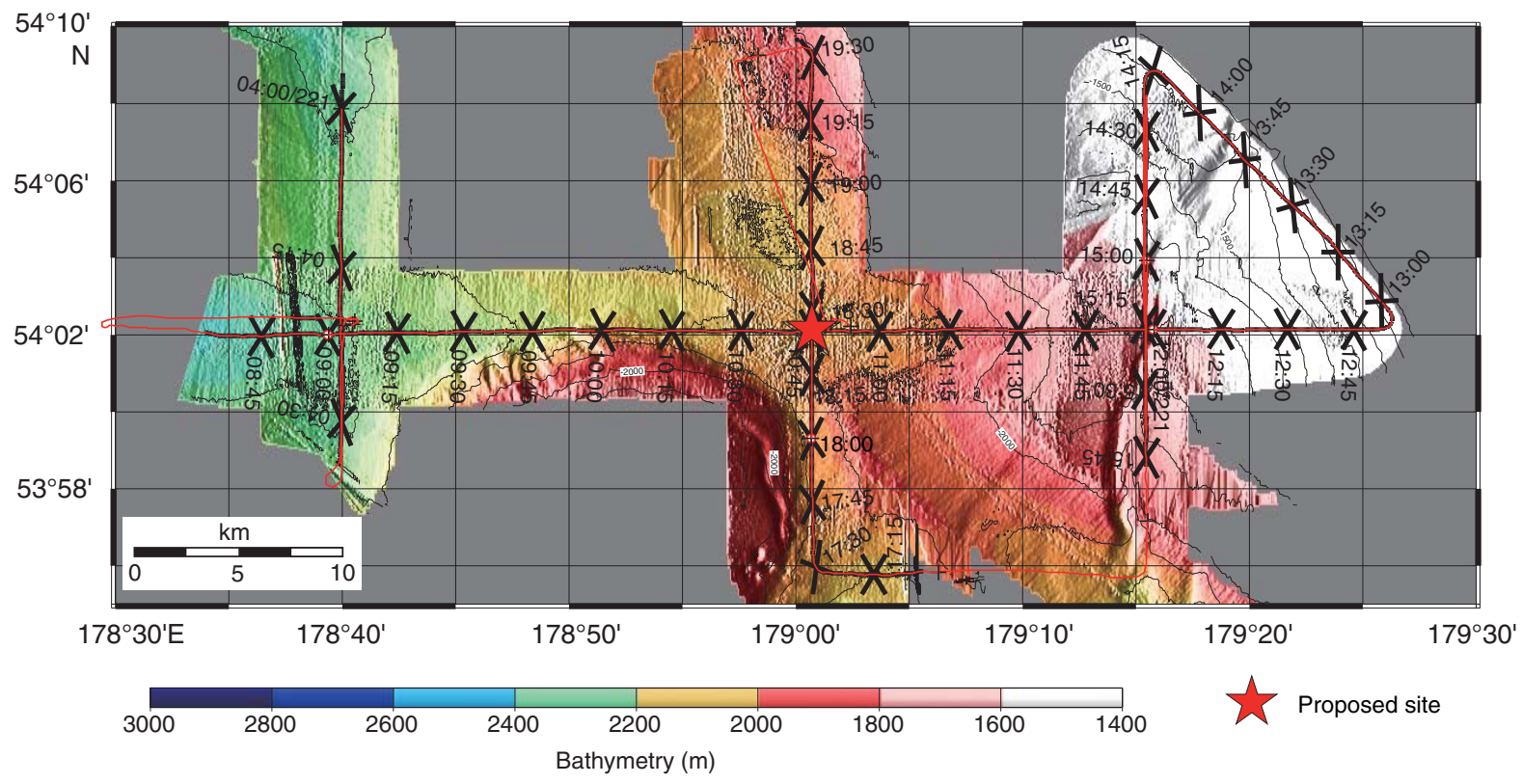


Figure F15. 3.5 kHz subbottom profiles from Cruise KH99-03, Site BOW-14. A. Line Stk5-1 (west-east). B. Line Stk5-5 (south-north).
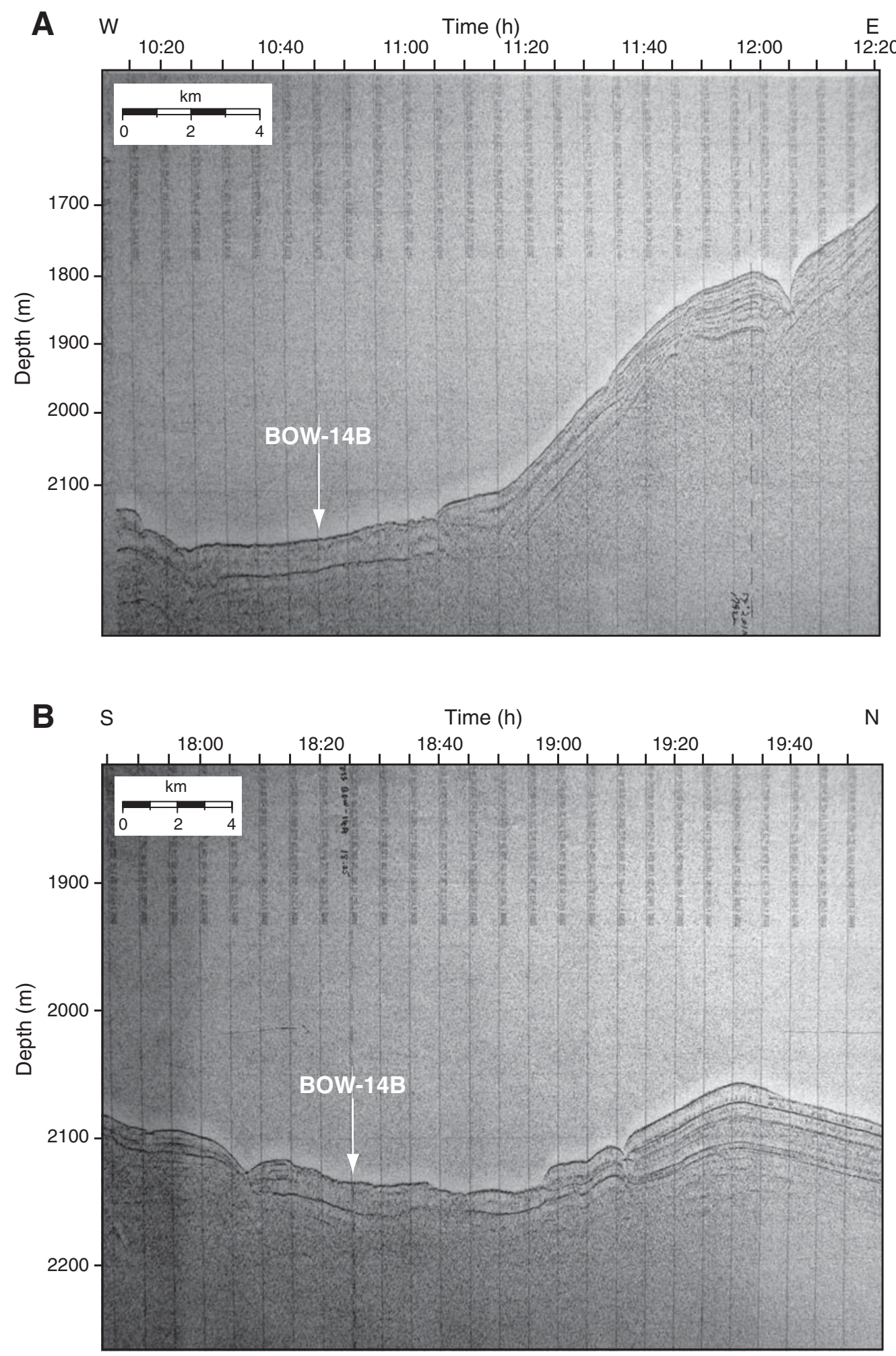
Figure F16. Seismic profile for Line Stk5-1 (west-east) from Cruise KH99-03, Site BOW-14B $\left(179^{\circ} 00.5^{\prime} \mathrm{E}, 4^{\circ} 02.0^{\prime} \mathrm{N}\right.$, Shotpoint 670 , water depth $=$ $2166 \mathrm{mbsl}$, penetration depth $=555-600 \mathrm{mbsf})$.

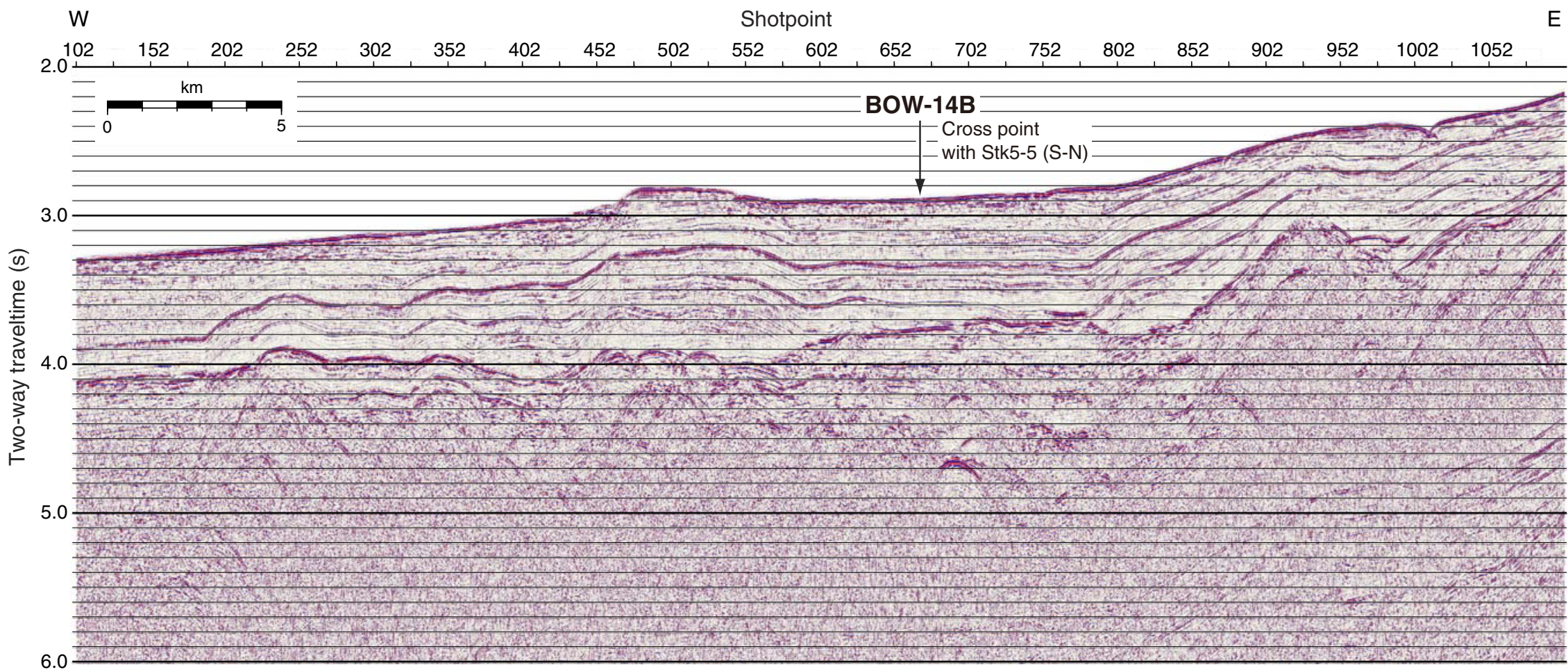


Figure F17. Seismic profile for Line Stk5-5 (south-north) from Cruise KH99-03, Site BOW-14B.

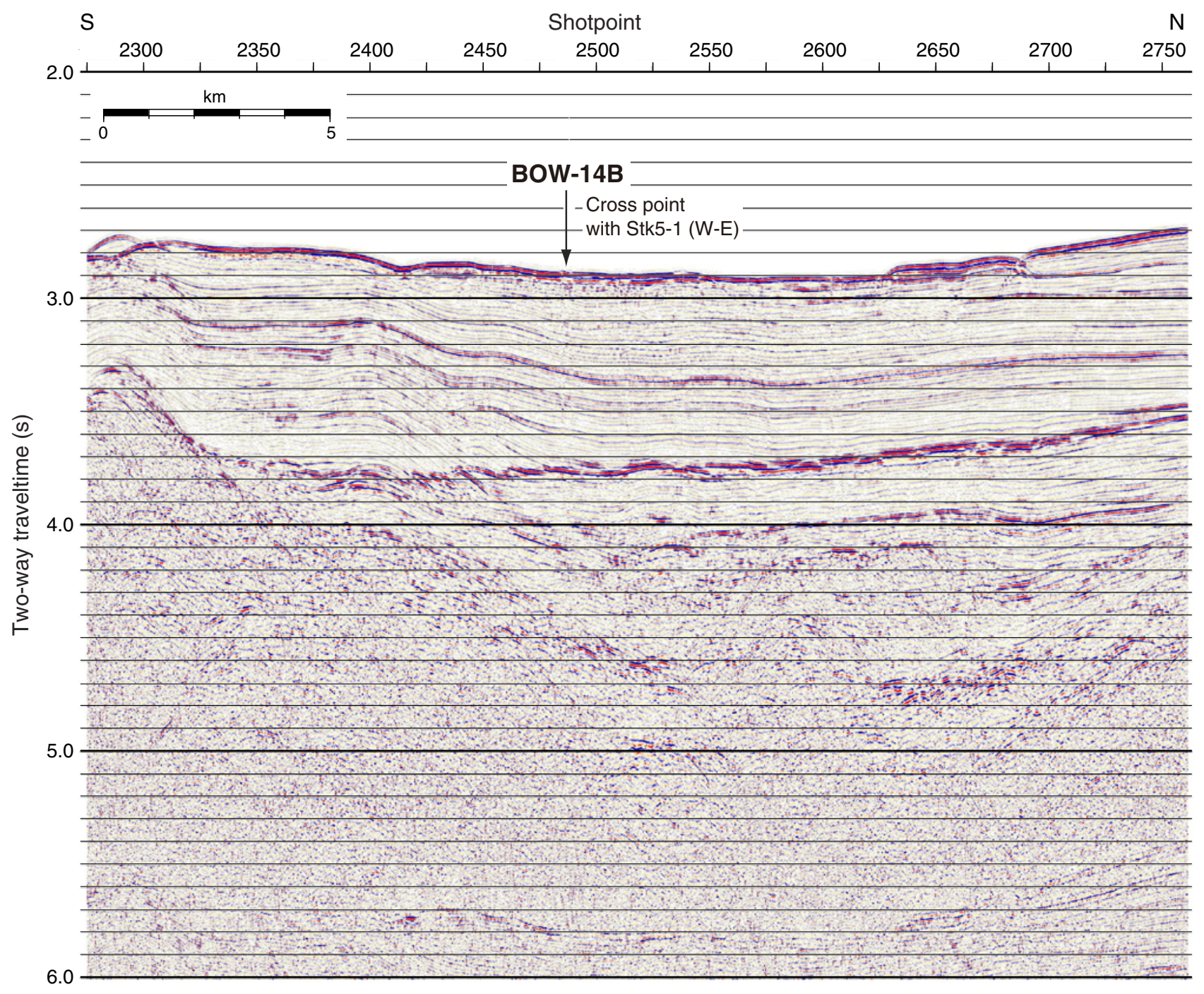


Figure F18. Close-up navigation map from Cruise KH99-03, Site BOW-14B.

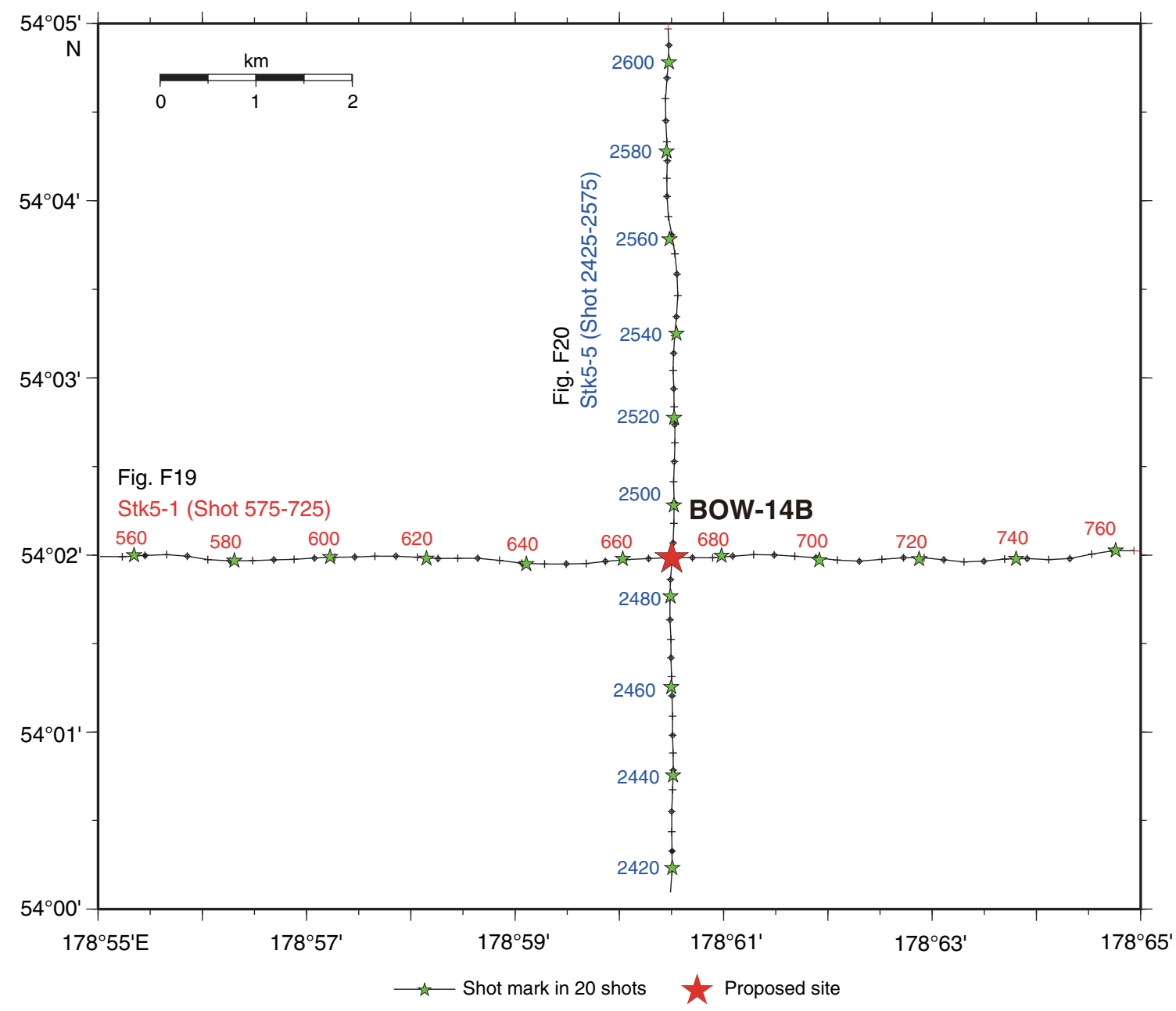


Figure F19. A. Close-up seismic profile for Line Stk5-1 (west-east) from Cruise KH99-3, Site BOW-14B. B. Time-depth curve estimated from results of velocity analyses on Lines Stk5-1 and Stk5-5.
A W
615
635
Shotpoint

$655 \quad 675$

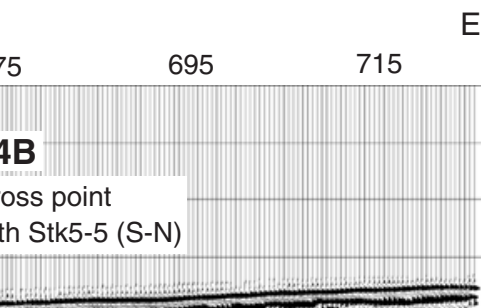

\section{BOW-14B}

with Stk5-5 (S-N)

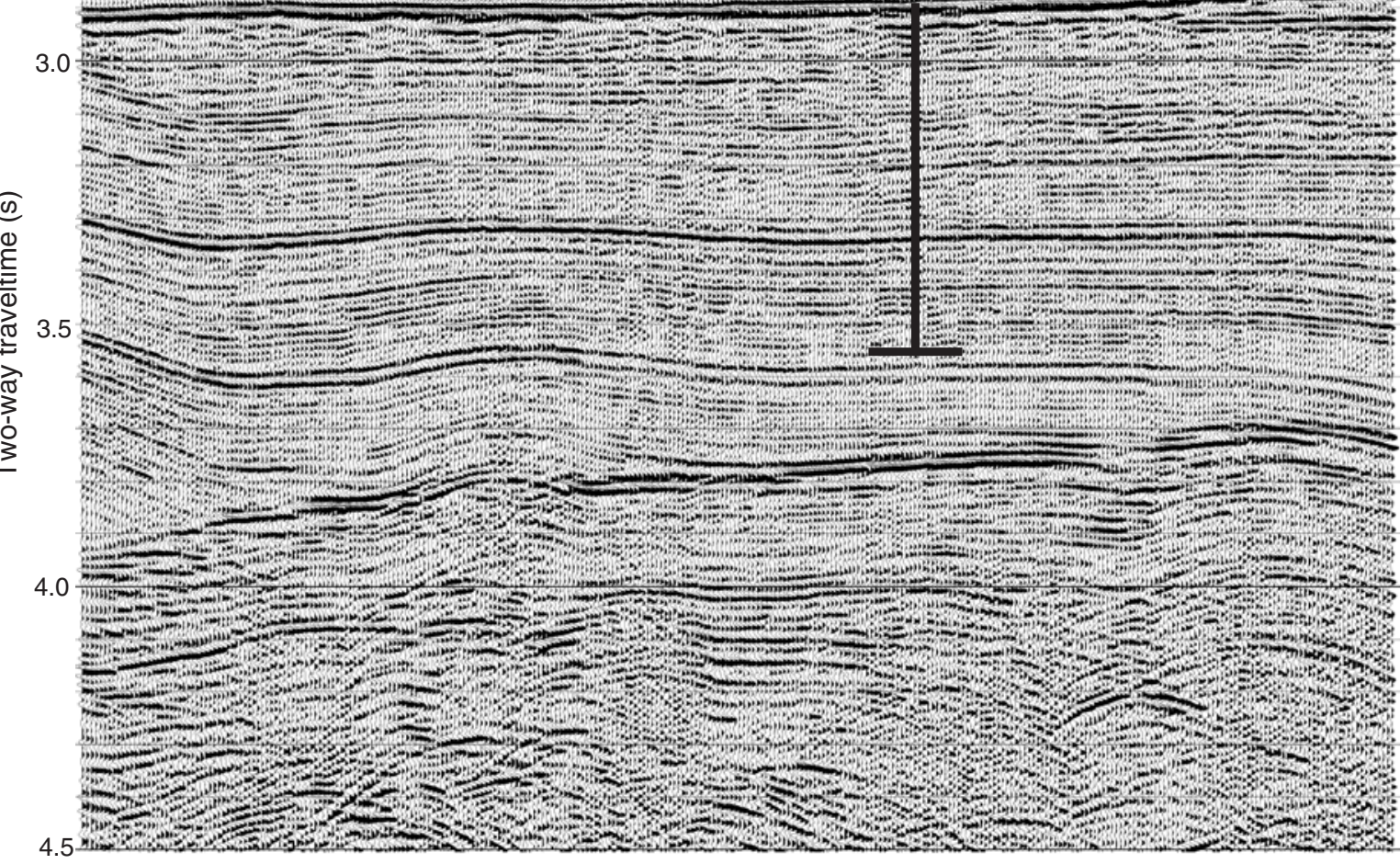

B Two-way traveltime below seafloor (s)

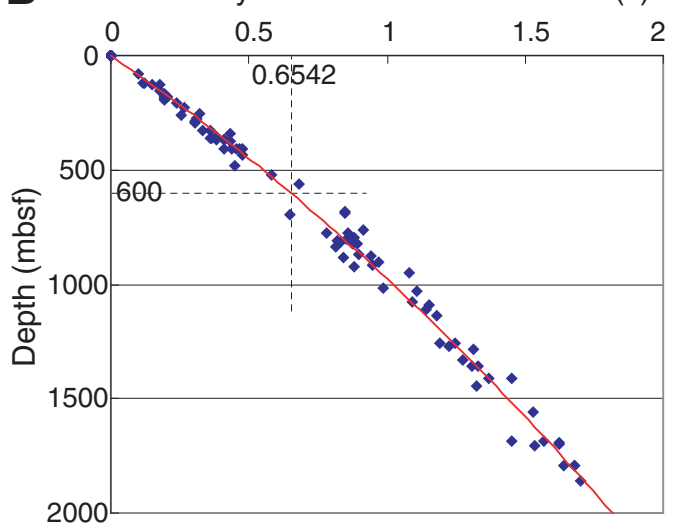


Figure F20. A. Close-up seismic profile for Line Stk5-5 (south-north) from Cruise KH99-3, Site BOW-14B. B. Time-depth curve estimated from results of velocity analyses on Lines Stk5-1 and Stk5-5.

A 5

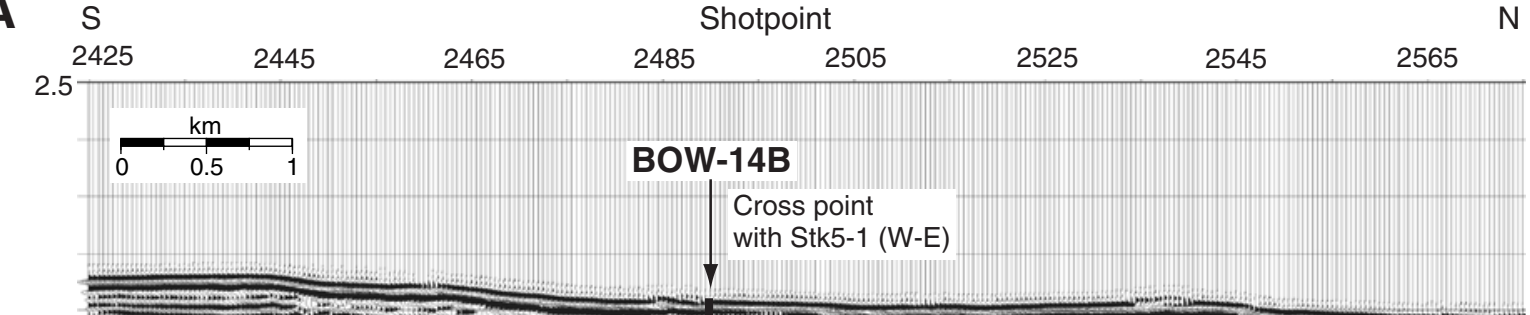

3.0

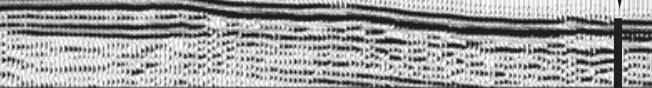
with Stk5-1 (W-E)
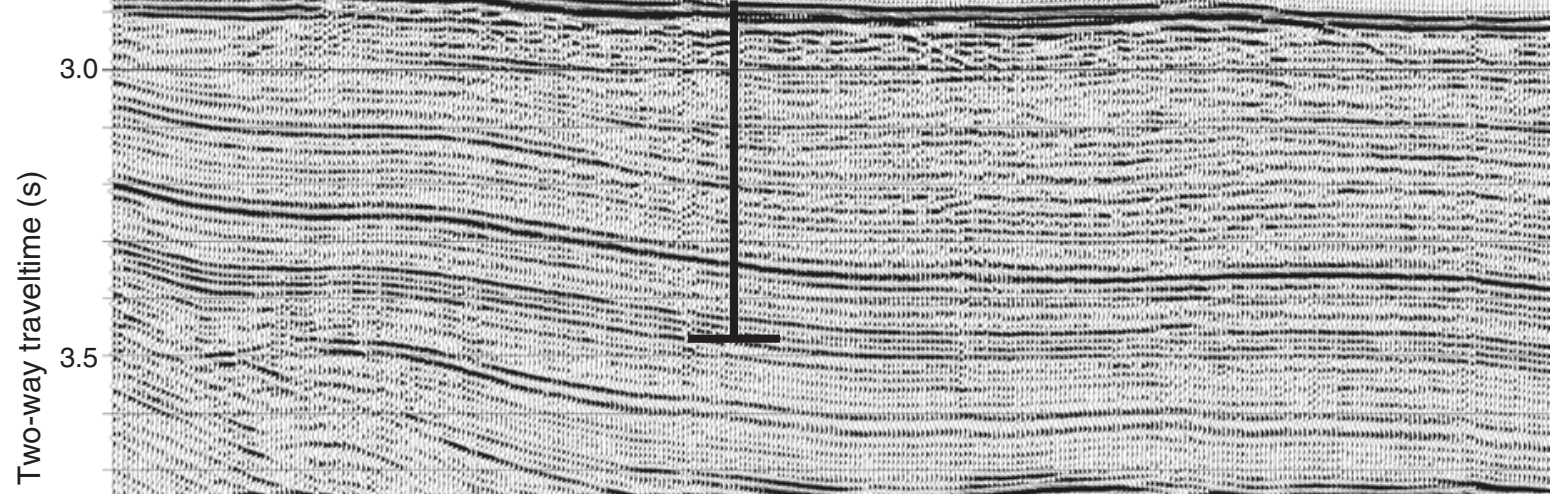

$$
\text { 1.t. }
$$

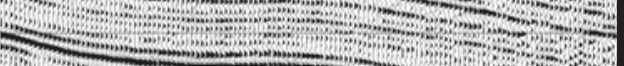

(3,

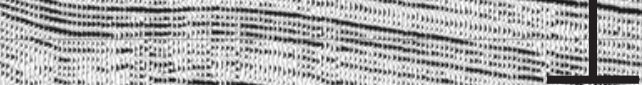

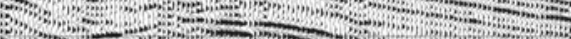

.

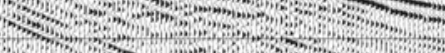

$\rightarrow \infty$

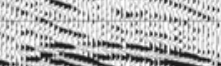

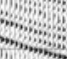

.

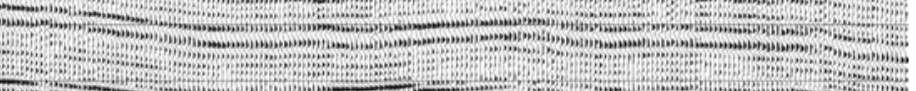

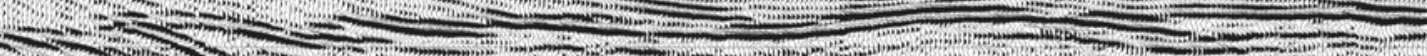

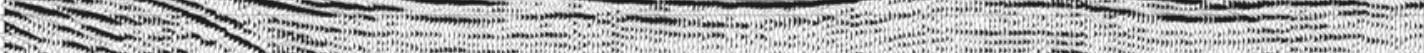

-

4.0

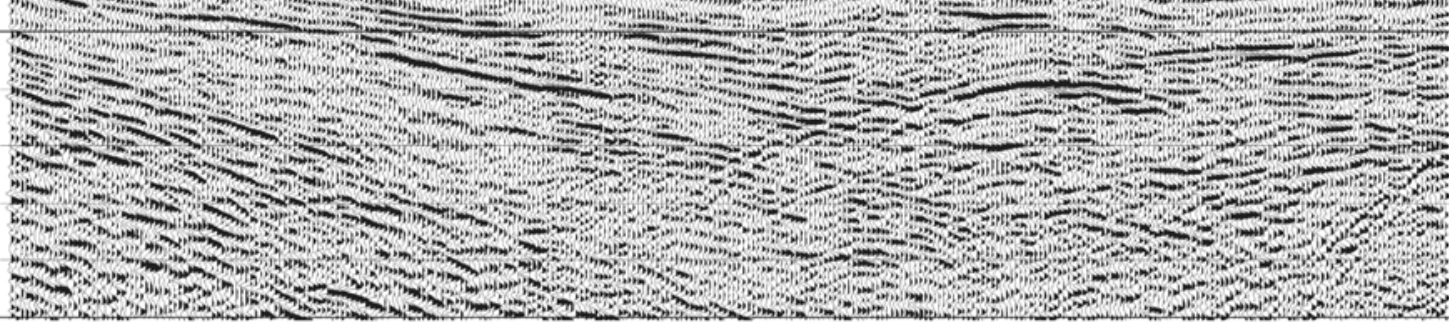

B Two-way traveltime below seafloor (s)

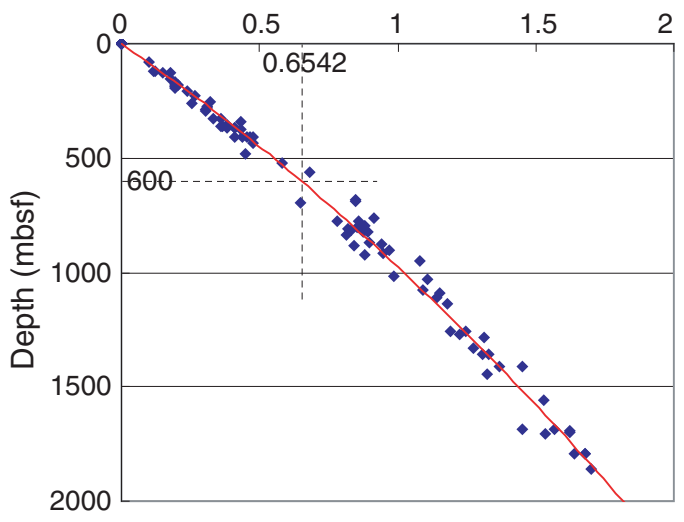


Figure F21. Seismic profiles with potential hazards (bottom-simulating reflector [BSR] annotation), Site BOW14B. See interval velocity analysis in Figure F12.

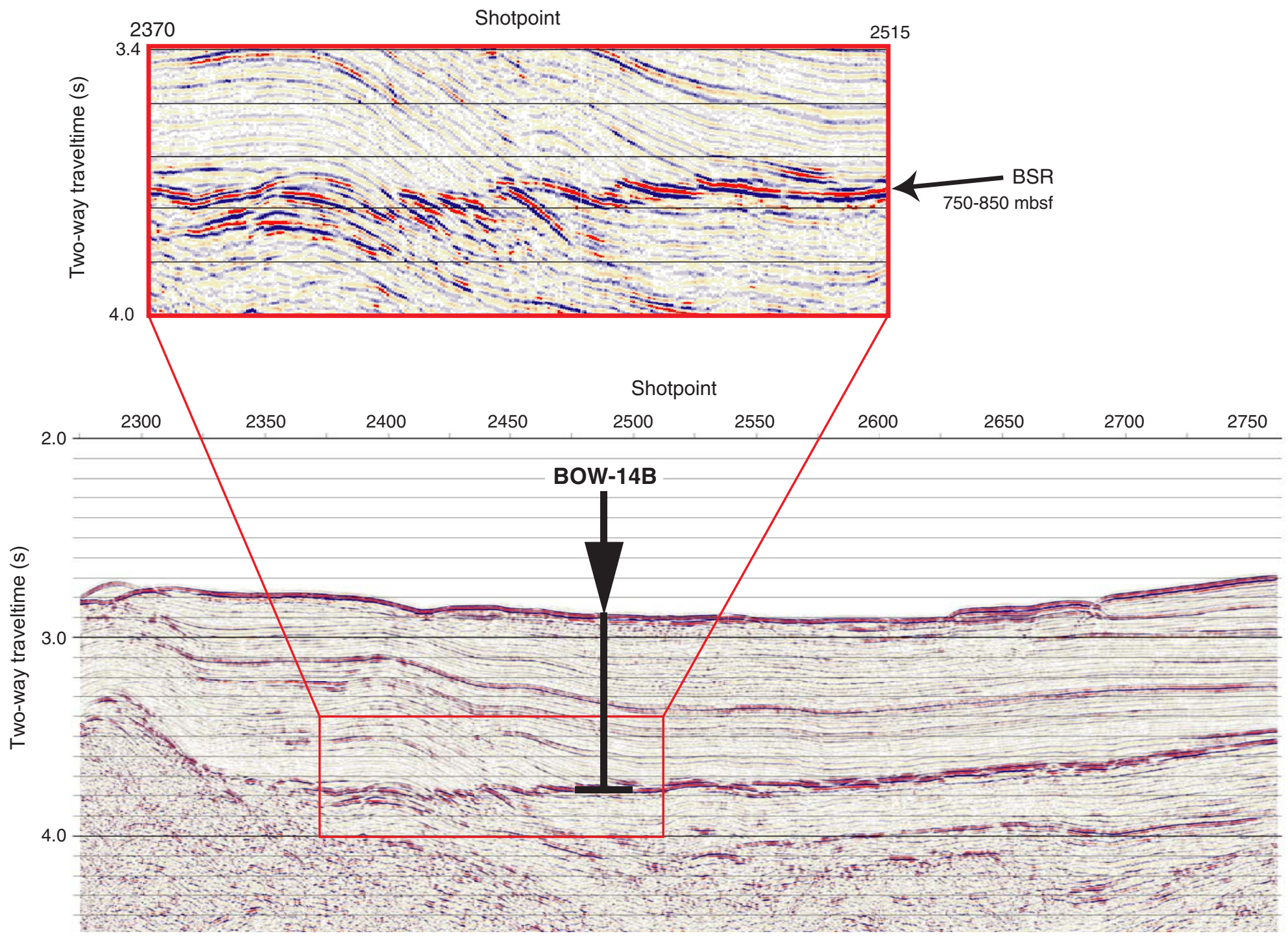


Figure F22. Specific navigation map of Cruise KH99-03, Site BOW-15A. Survey line crossing at 19:21:35 h, Shotpoint 1203, Line Stk4-3 (west-east) and 16:20:40 h, Shotpoint 505, Line Stk4-1 (north-south). Site BOW-15A at 15:58:30 h, Shotpoint 410, Line Stk4-1 (north-south). Close-up navigation shown in Figure F24.

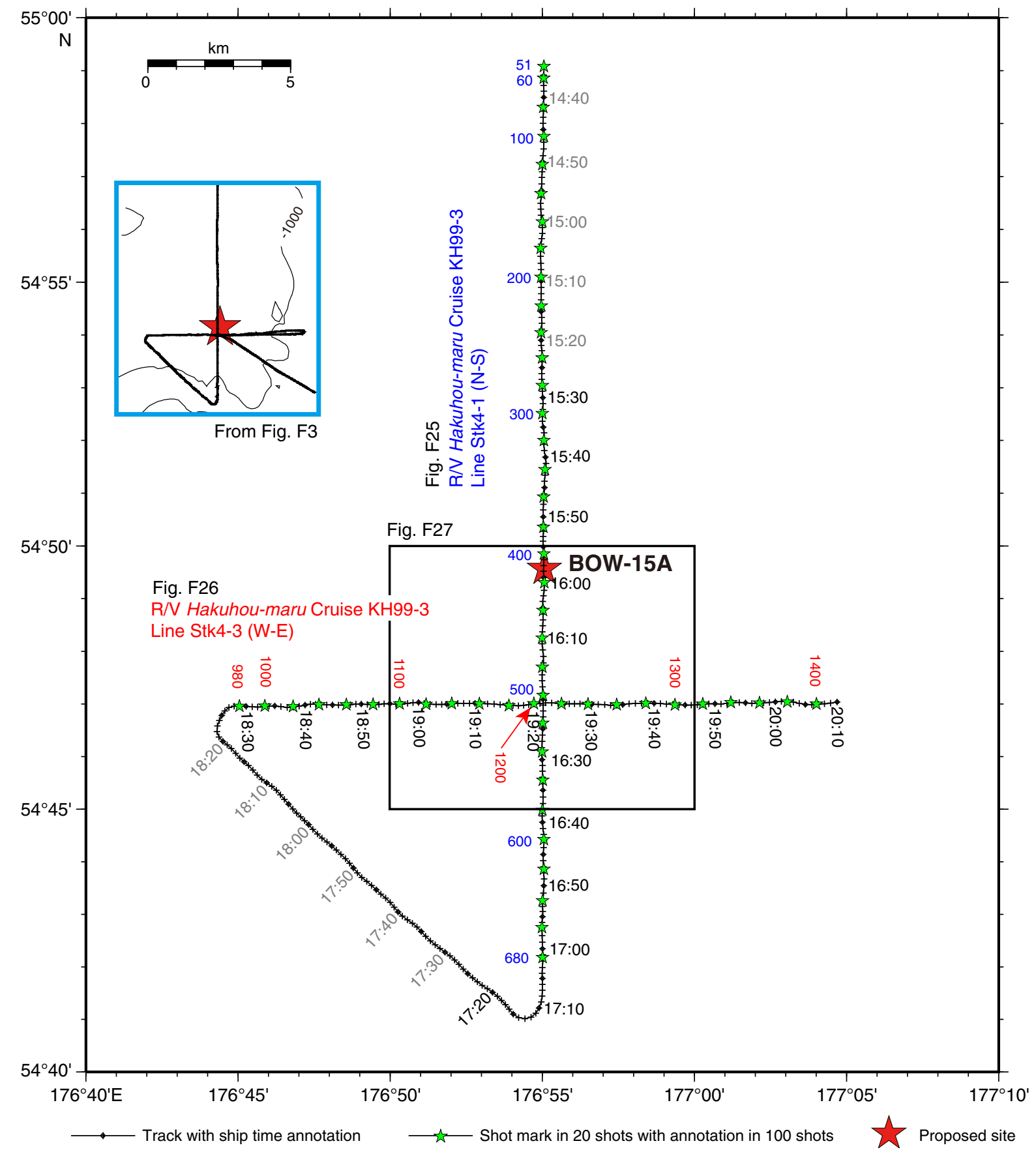




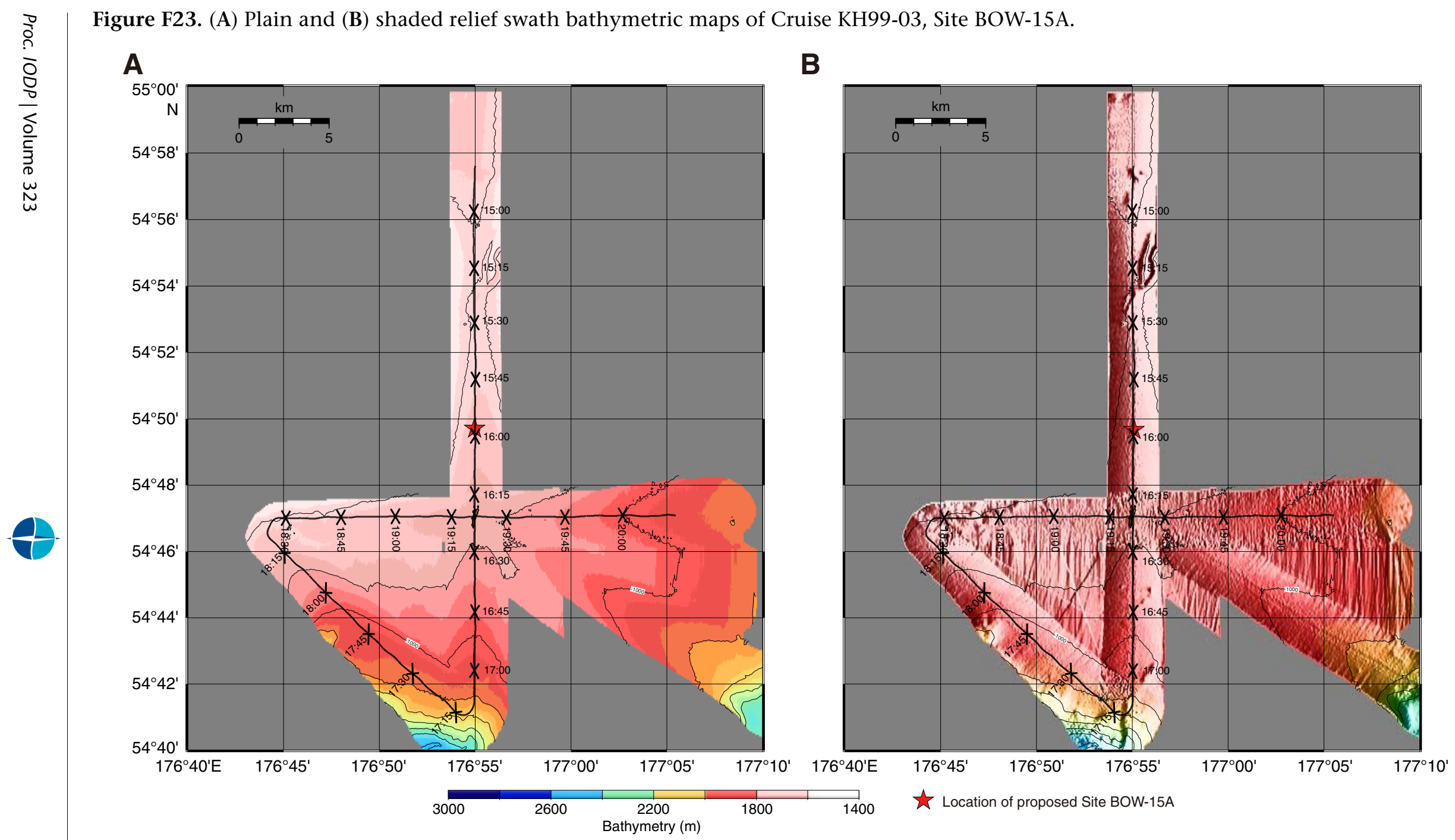


Figure F24. 3.5 kHz subbottom profiles for Cruise KH99-03, Site BOW-15A. A. Line Stk4-3 (west-east). B. Line Stk4-1 (north-south).
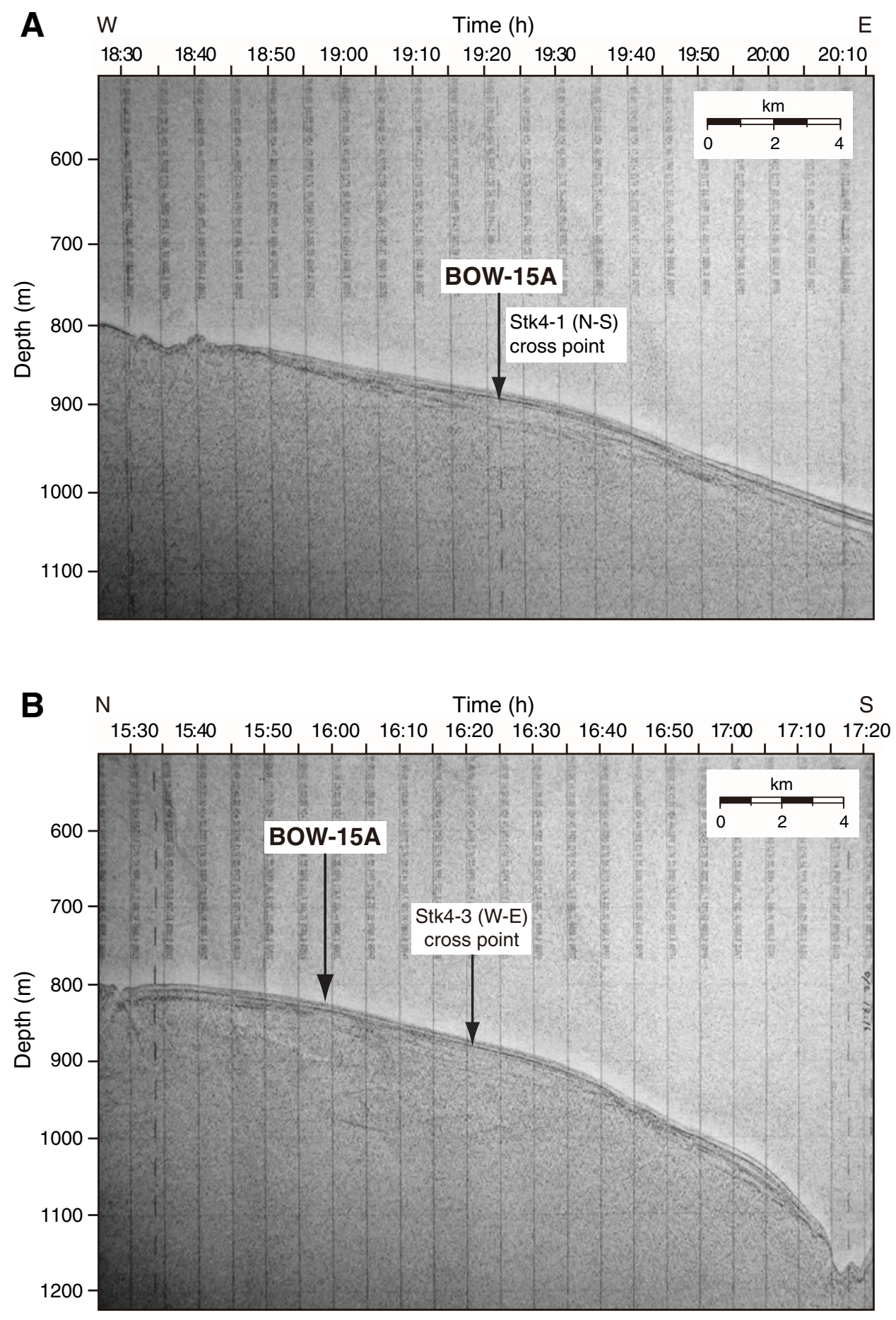
Figure F25. Seismic profile of Line Stk4-1 (north-south) from Cruise KH99-03, Site BOW-15A (176 $55.0^{\prime} \mathrm{E}, 54^{\circ} 49.7^{\prime} \mathrm{N}$, Shotpoint 410 , water depth $=837 \mathrm{mbsl}$, penetration depth $=120-165 \mathrm{mbsf})$.

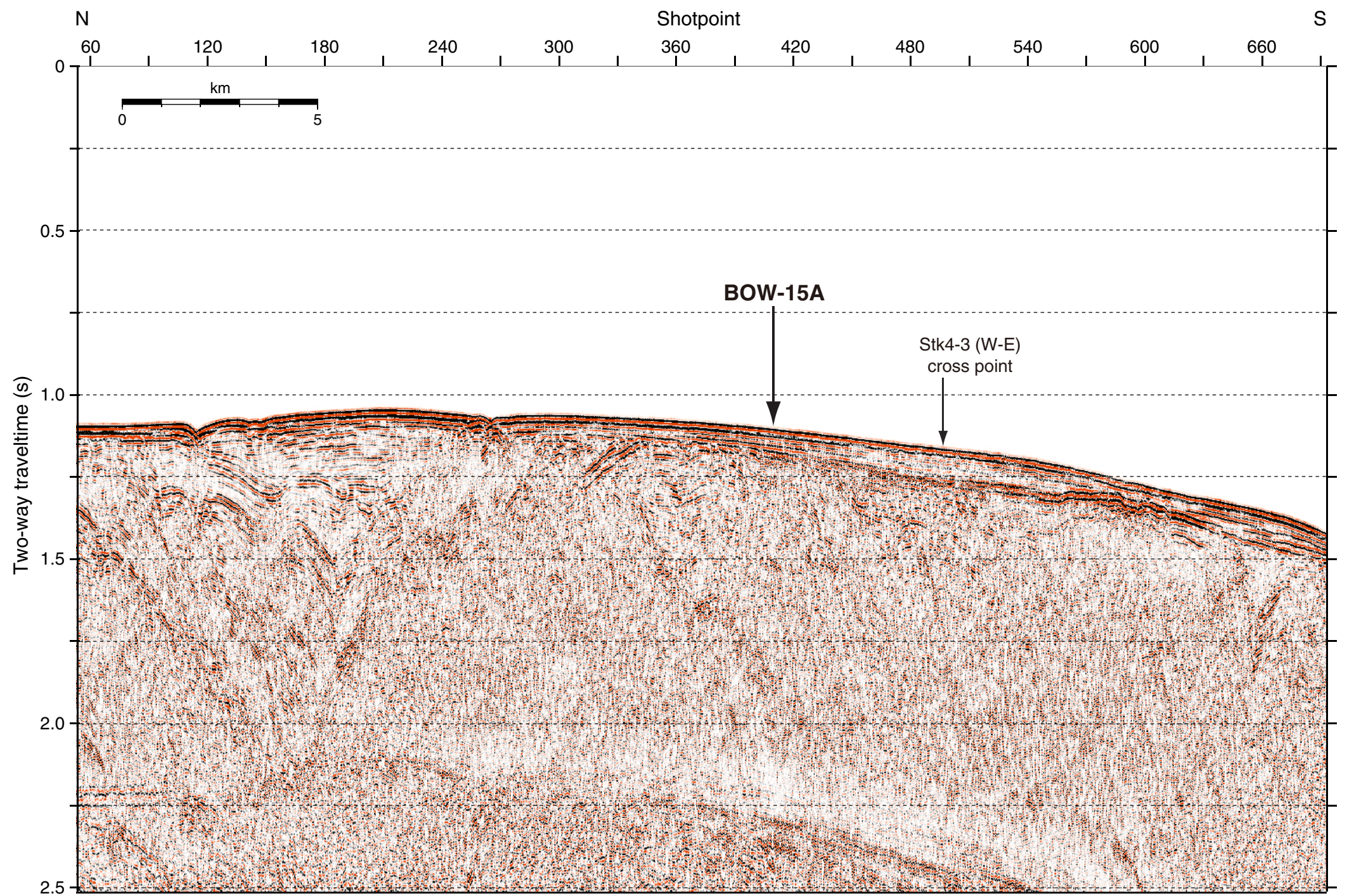


Figure F26. Seismic profile of Line Stk4-3 (west-east) from Cruise KH99-03, Site BOW-15A.

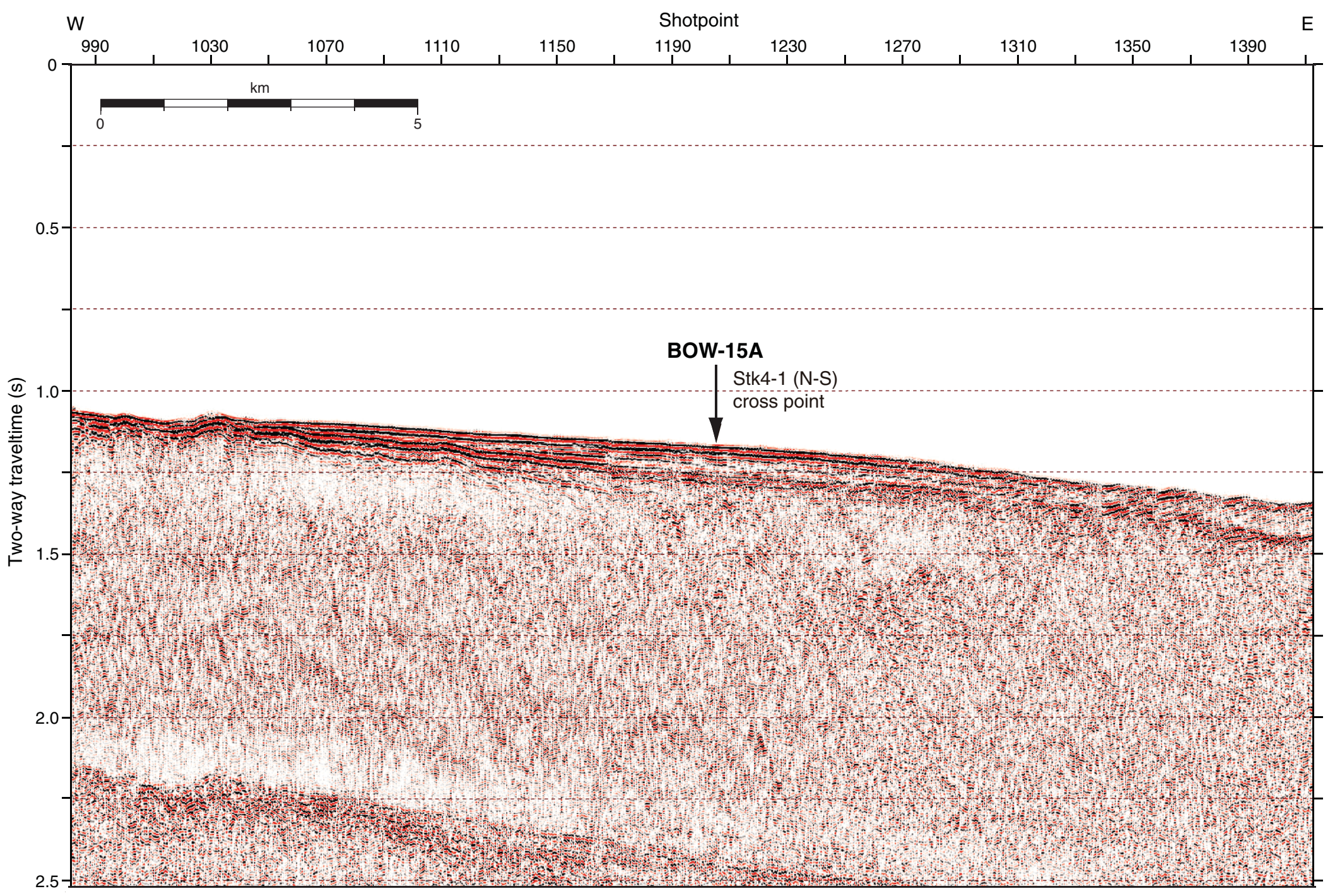


Figure F27. Regional overview map of Bering/Arctic gateway sites. Close-up maps of navigation are shown in Figures F28 and F36.

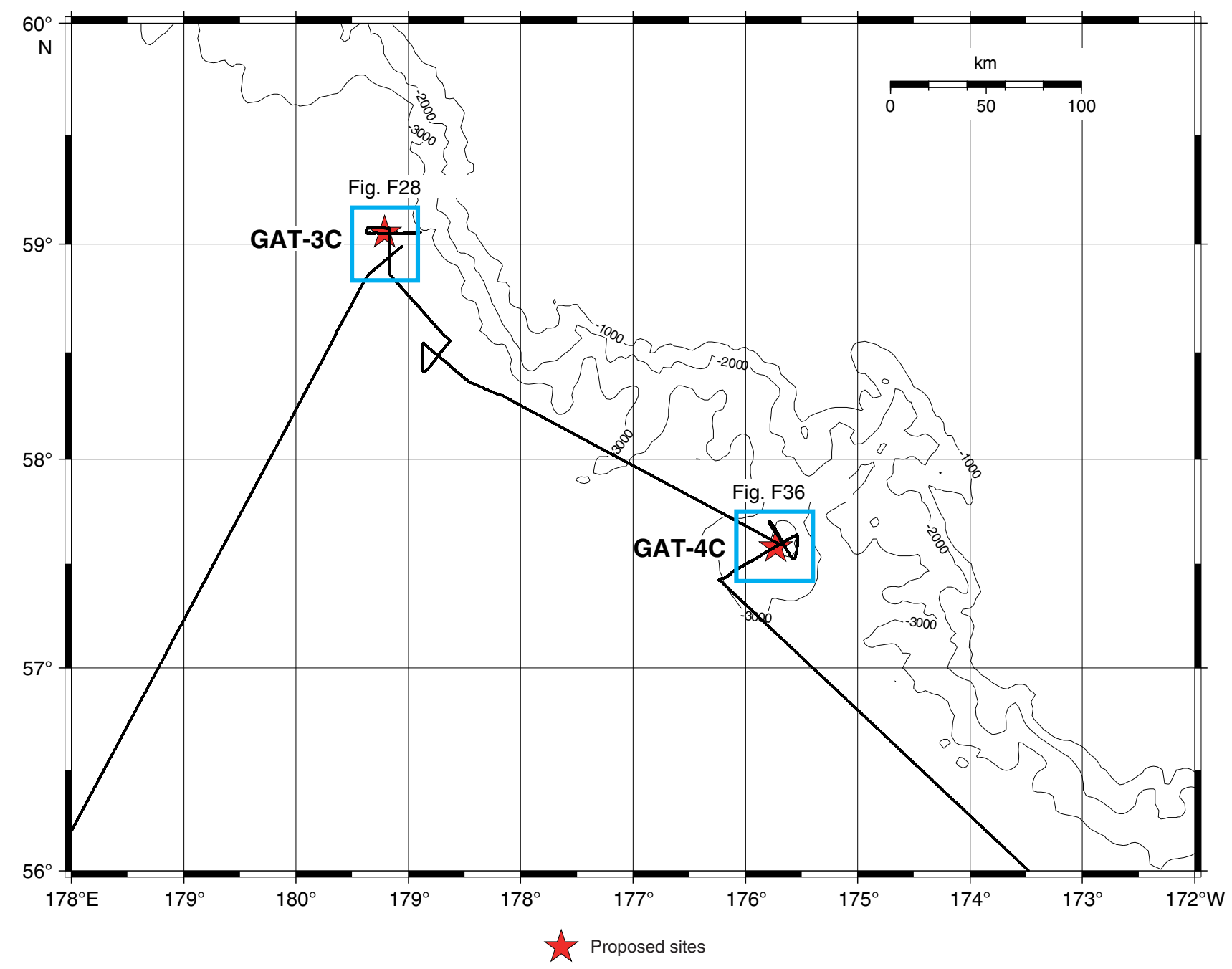


Figure F28. Navigation maps for Cruise KH99-03, Site GAT-3C. A. Specific navigation map. Crossing point at Shotpoint 2899 on Line Stk3-7 (westeast) and Shotpoint 2510 on Line Stk3-5 (south-north). Proposed site at Shotpoint 2860 on Line Stk3-7 (west-east). B. Close-up navigation map.

A

$59^{\circ} 10^{\prime}$

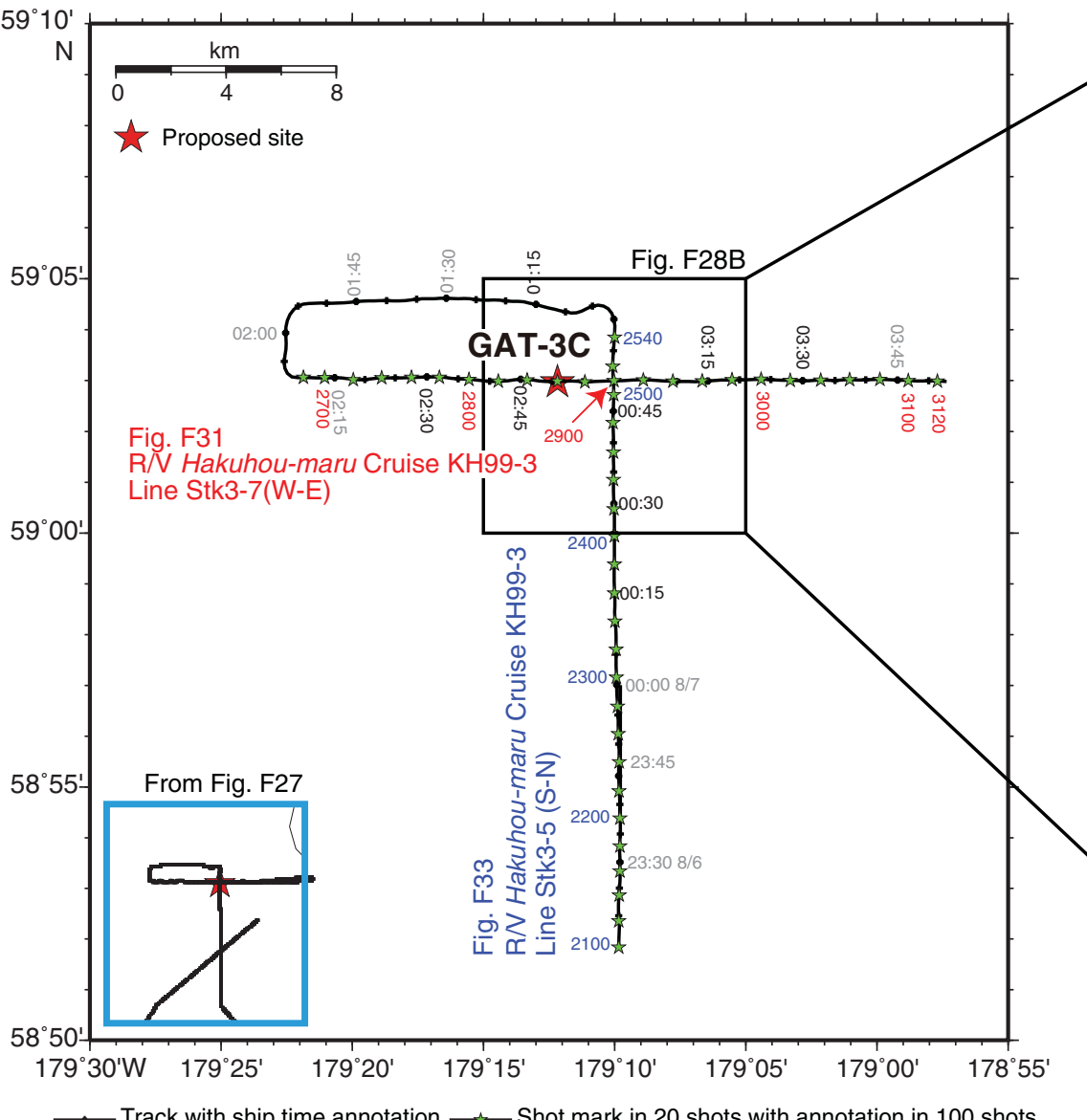

—. Track with ship time annotation —— Shot mark in 20 shots with annotation in 100 shots
B

$59^{\circ} 05^{\prime}$

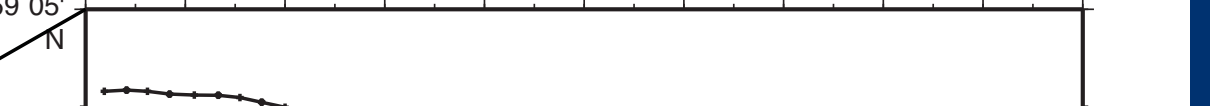

$59^{\circ} 04^{\prime}$

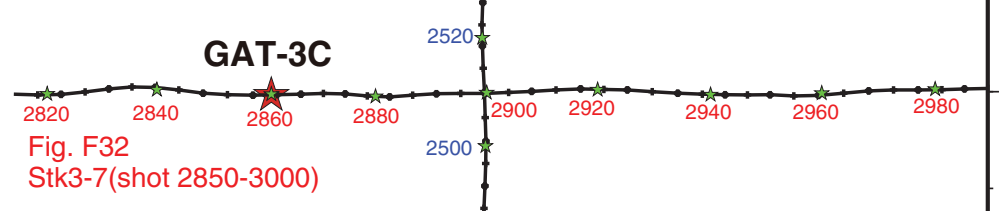

$59^{\circ} 01^{\prime}$

$59^{\circ} 02^{\prime}$

Stk3-7(shot 2850-3000)

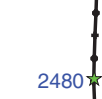

$\longrightarrow$ Shot mark in 20 shots $九$ Proposed site 
A

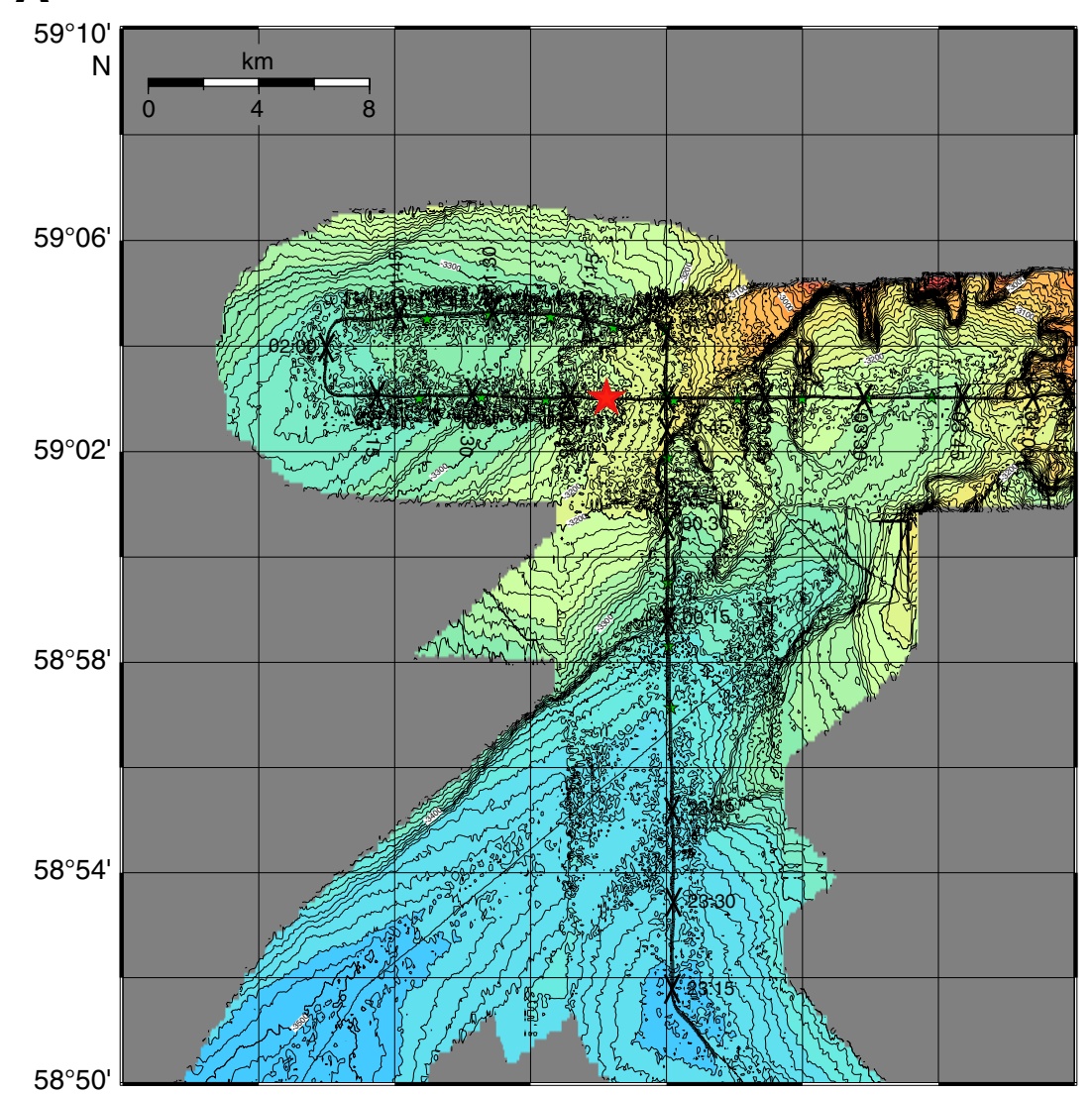

$179^{\circ} 30^{\prime} \mathrm{W}$

$179^{\circ} 20^{\prime}$

$179^{\circ} 00^{\prime}$
B

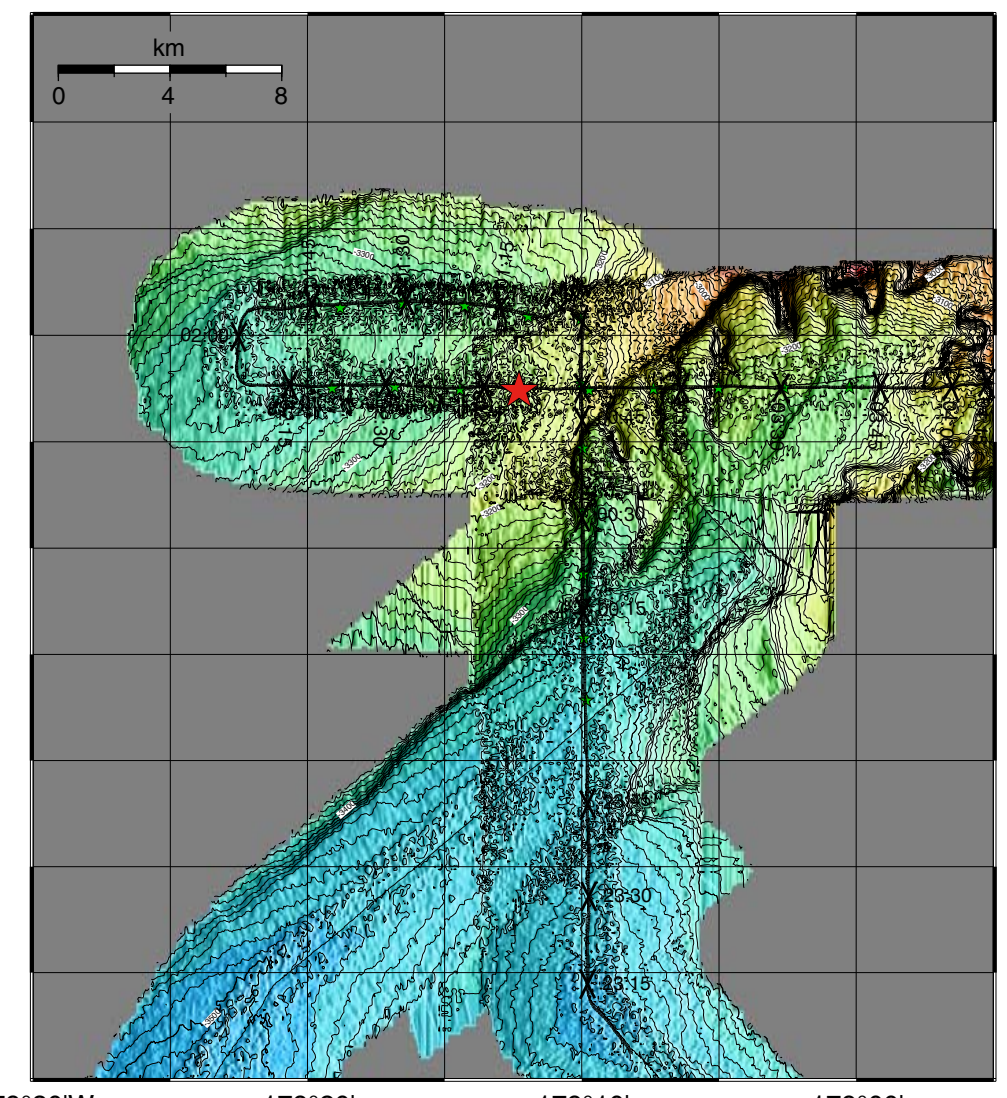

$179^{\circ} 30^{\prime} \mathrm{W}$

$179^{\circ} 20^{\prime}$

$179^{\circ} 10^{\prime}$

$179^{\circ} 00^{\prime}$

$\begin{array}{llllllllll}4000 & 3800 & 3600 & 3400 & 3200 & 3000 & 2800 & 2600 & 2400 & 2200\end{array}$ Bathymetry $(\mathrm{m})$ 
Figure F30. $3.5 \mathrm{kHz}$ subbottom profiles from Cruise KH99-03, Site GAT-3C. A. Line Stk3-7 (west-east). B. Line Stk3-5 (north-south).
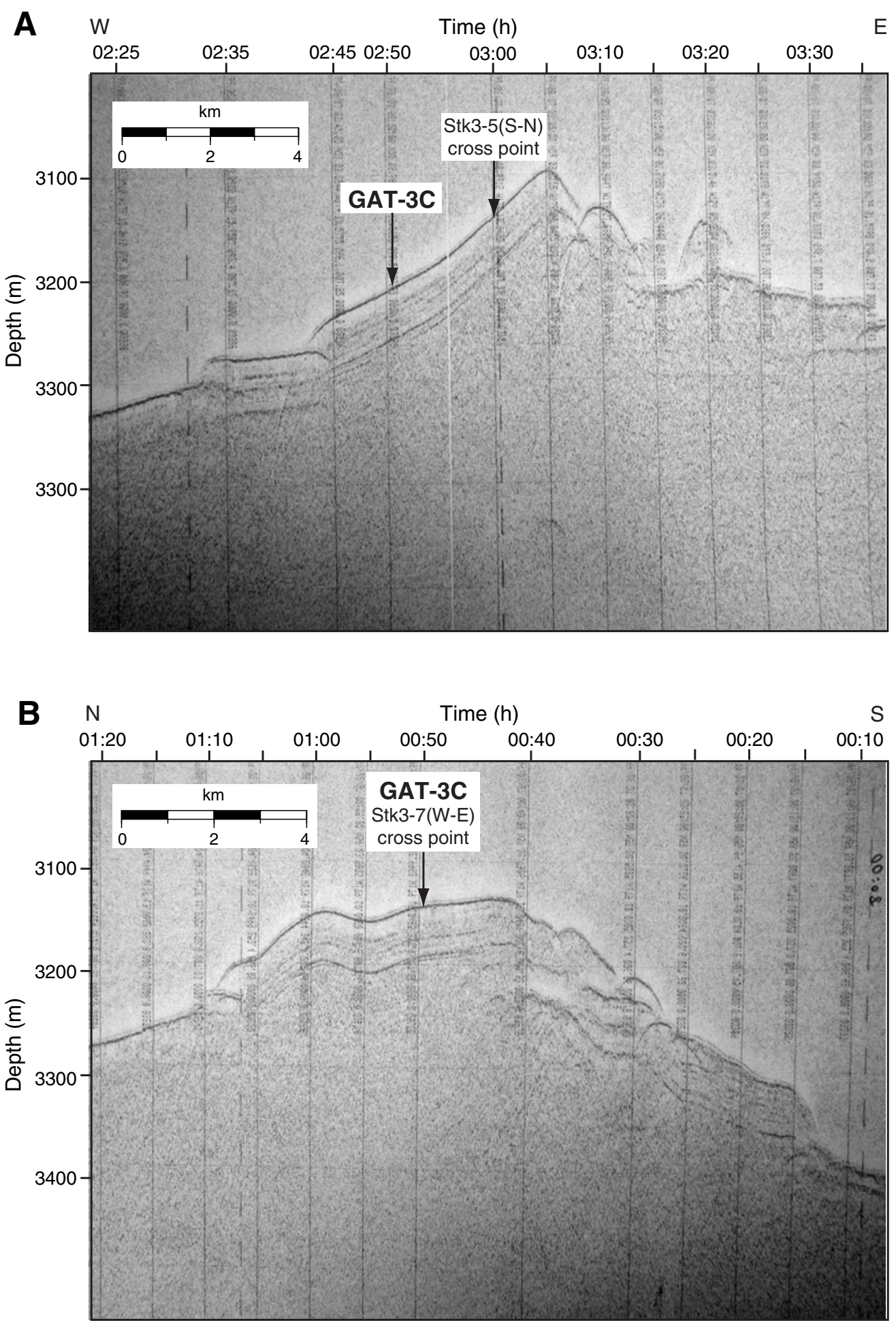
Figure F31. Seismic profile for Line Stk3-7 (west-east) from Cruise KH99-3, Site GAT-3C $\left(179^{\circ} 12.2^{\prime} \mathrm{W}, 59^{\circ} 03.0^{\prime} \mathrm{N}\right.$, Shotpoint 2860, water depth $=3209 \mathrm{mbsl}$, penetration depth $=700-745 \mathrm{mbsf}$ ).

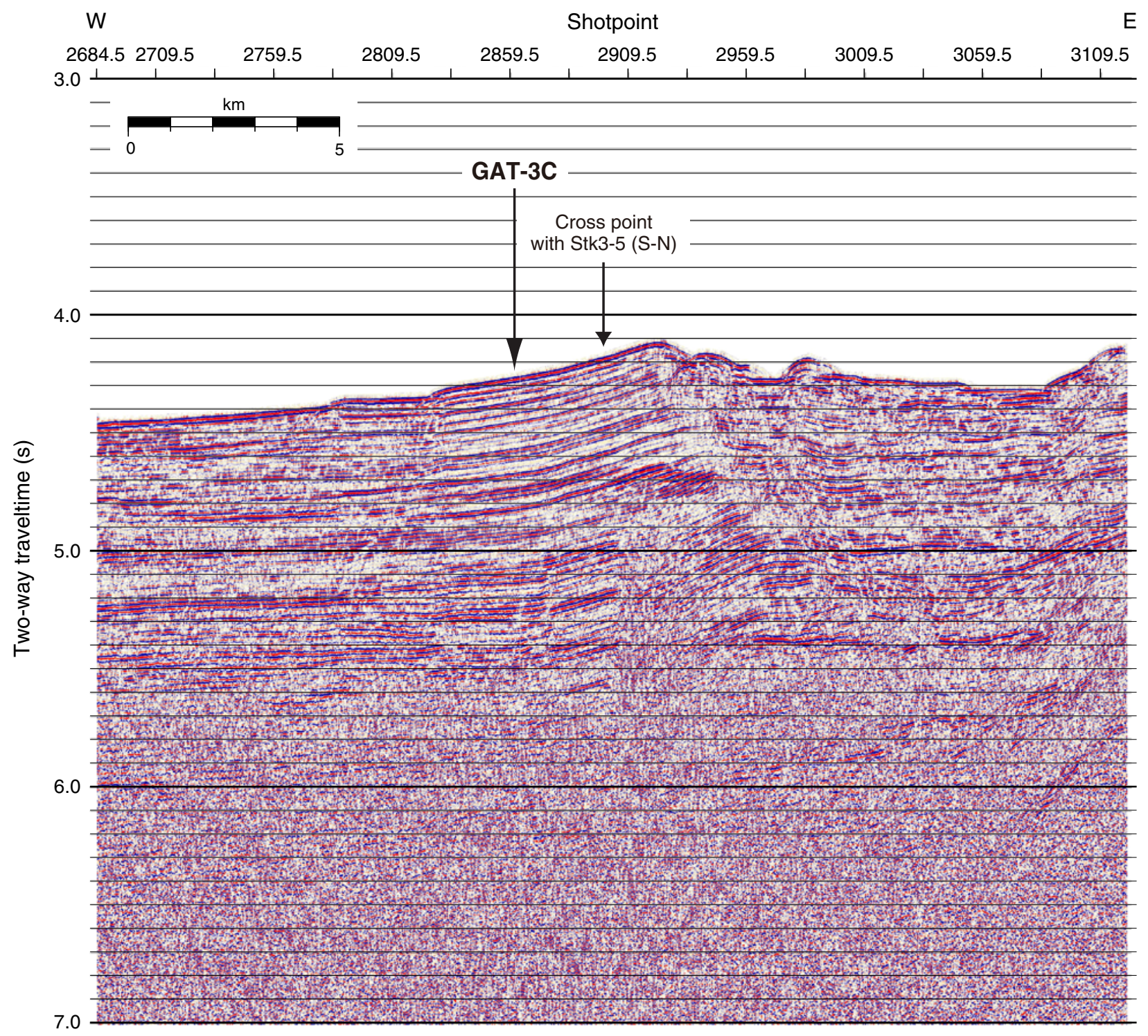


Figure F32. A. Close-up seismic profile for Line Stk3-7 (west-east) from Cruise KH99-3, Site GAT-3C. B. Time-depth curve estimated from results of velocity analyses on Lines Stk3-5 and Stk3-7.
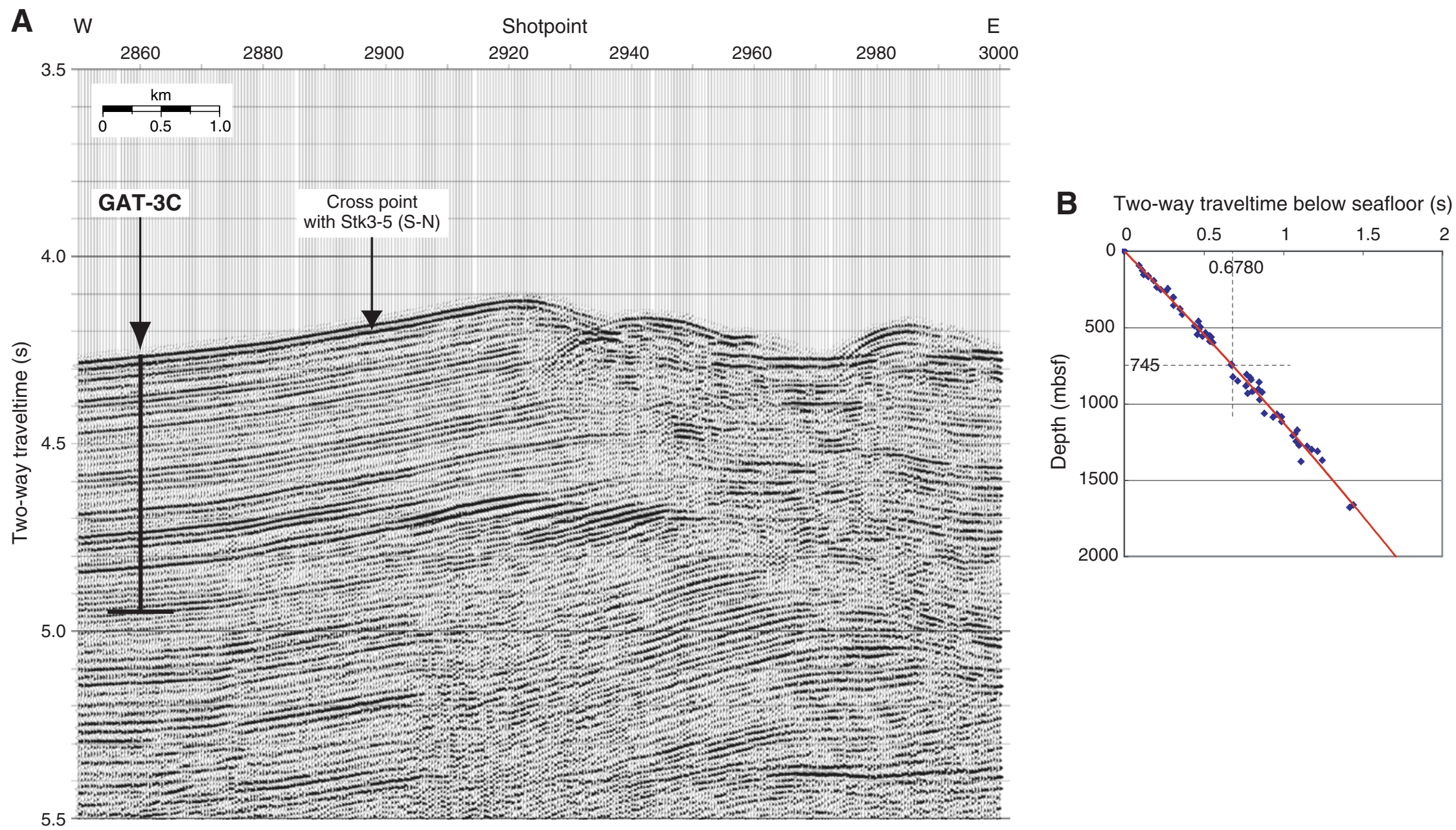
Figure F33. Seismic profile for Line Stk3-5 (north-south) from Cruise KH99-3, Site GAT-3C.

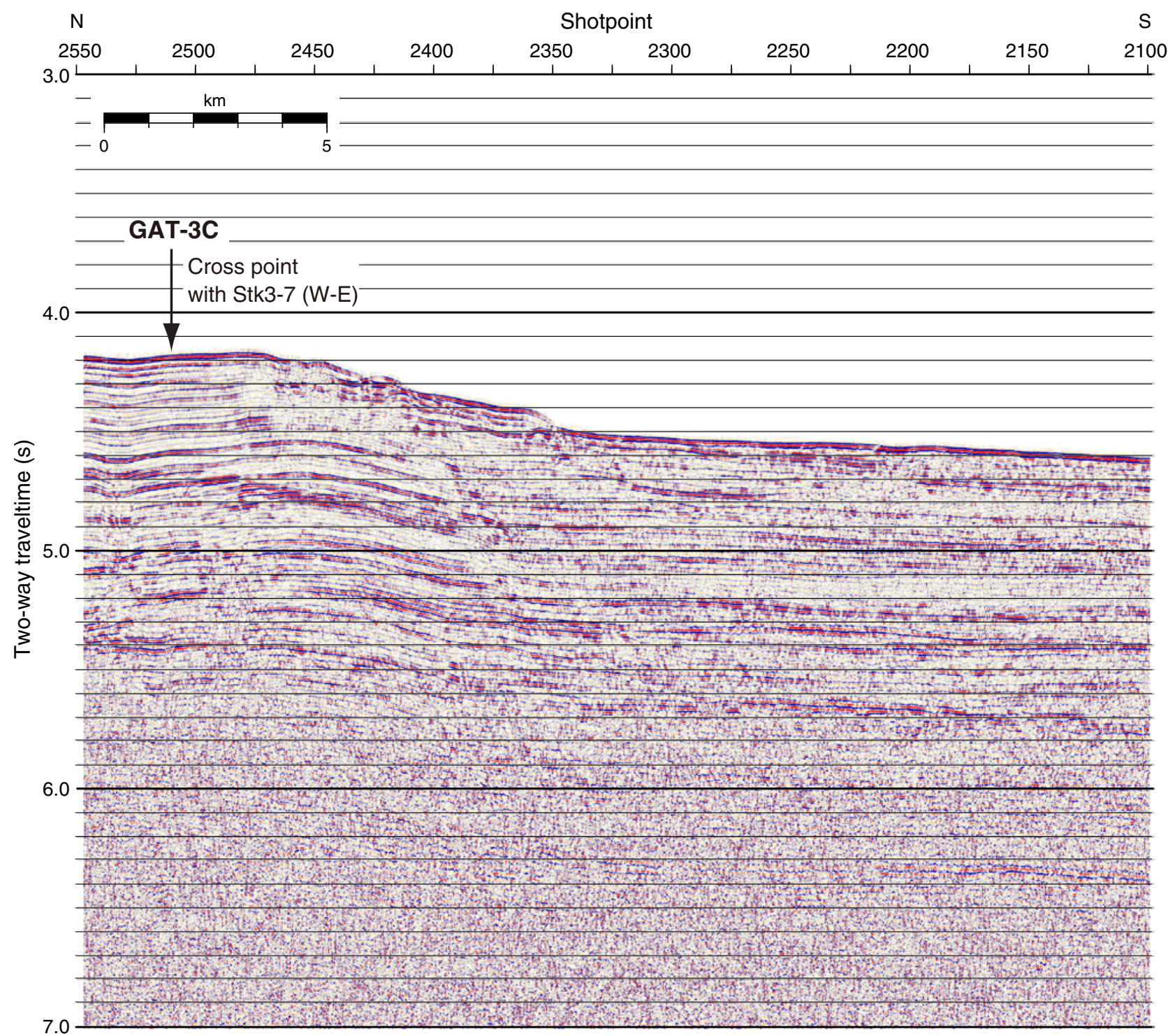


Figure F34. A. Close-up seismic profile of Line Stk3-5 (north-south) from Cruise KH99-3, Site GAT-3C. B. Time-depth curve estimated from results of velocity analyses on Lines Stk3-5 and Stk3-7.
A $\quad \mathrm{N}$
GAT-3C
Shotpoint
$2460 \quad 2440$
$2440 \quad 2420$

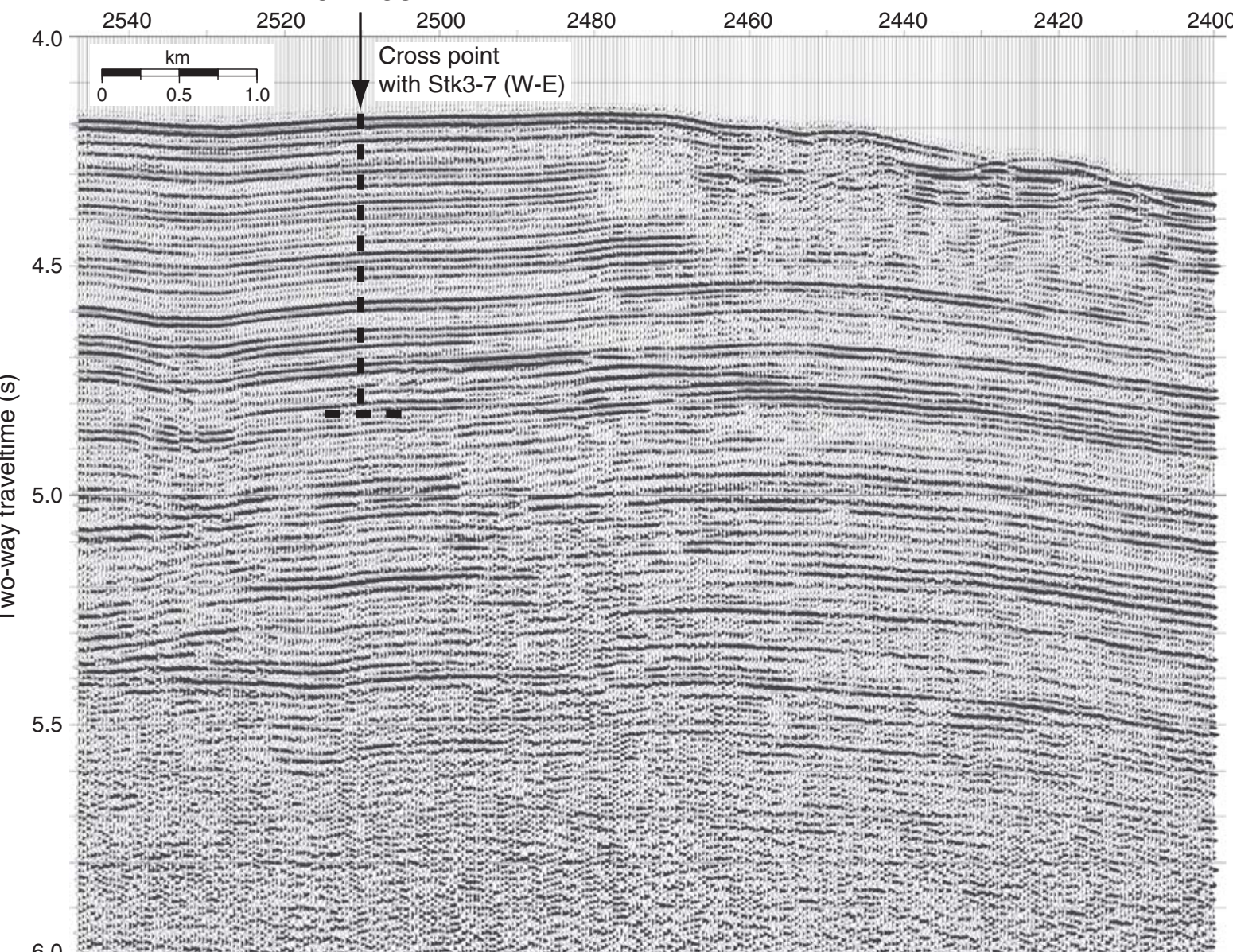

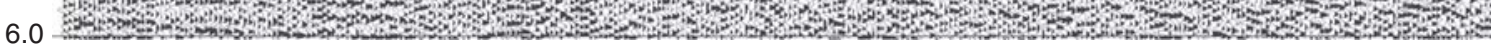

B Two-way traveltime below seafloor (s)

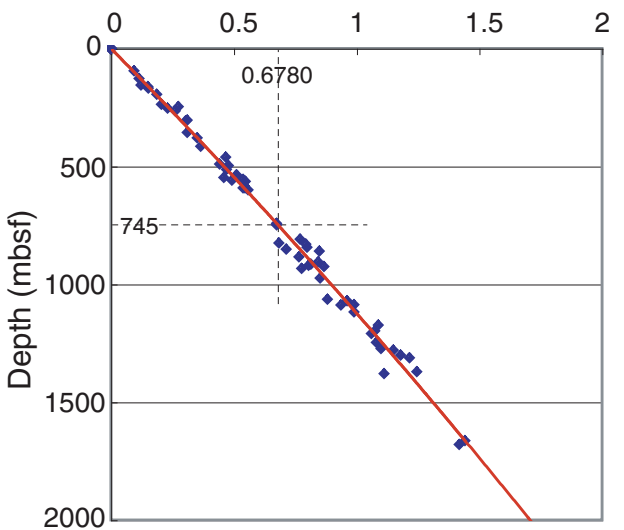


Figure F35. Interval velocity analyses from Cruise KH99-3 for (A) Line Stk3-5 at Site GAT-3C and (B) Line Stk2 at Site GAT-4C. BSR = bottom-simulating reflector.

A

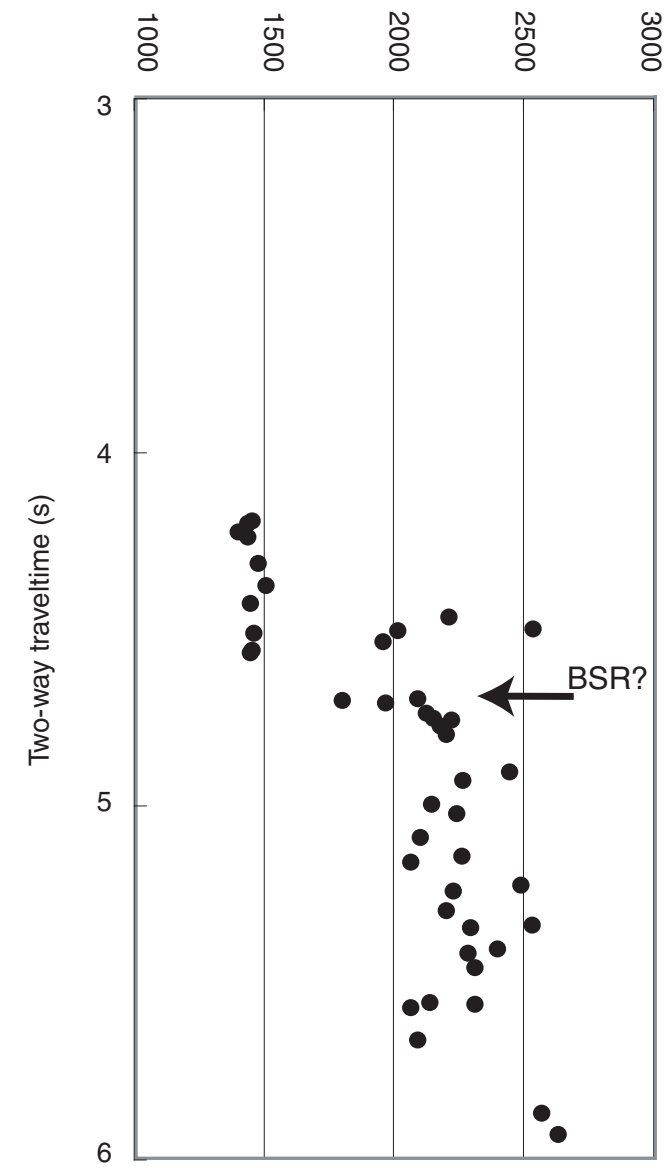

ద్ర
B $P$-wave velocity $(\mathrm{m} / \mathrm{s})$

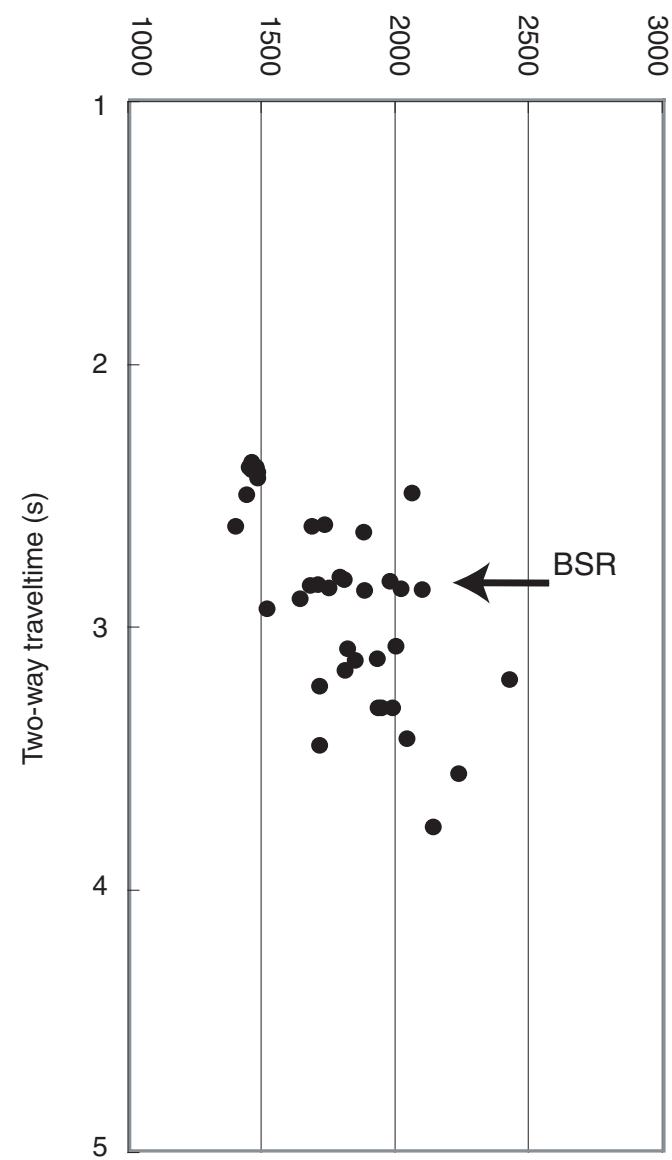


Figure F36. Specific navigation map of Cruise KH99-03, Site GAT-4C. Crossing point at 23:44:40 h, Shotpoint 553, on Line Stk1 (southwest-northeast) and 02:37:55 h, Shotpoint 400, on Line Stk2 (southeast-northwest). Proposed site at 22:50:55 h, Shotpoint 351, on Line Stk1 (southwest-northeast).

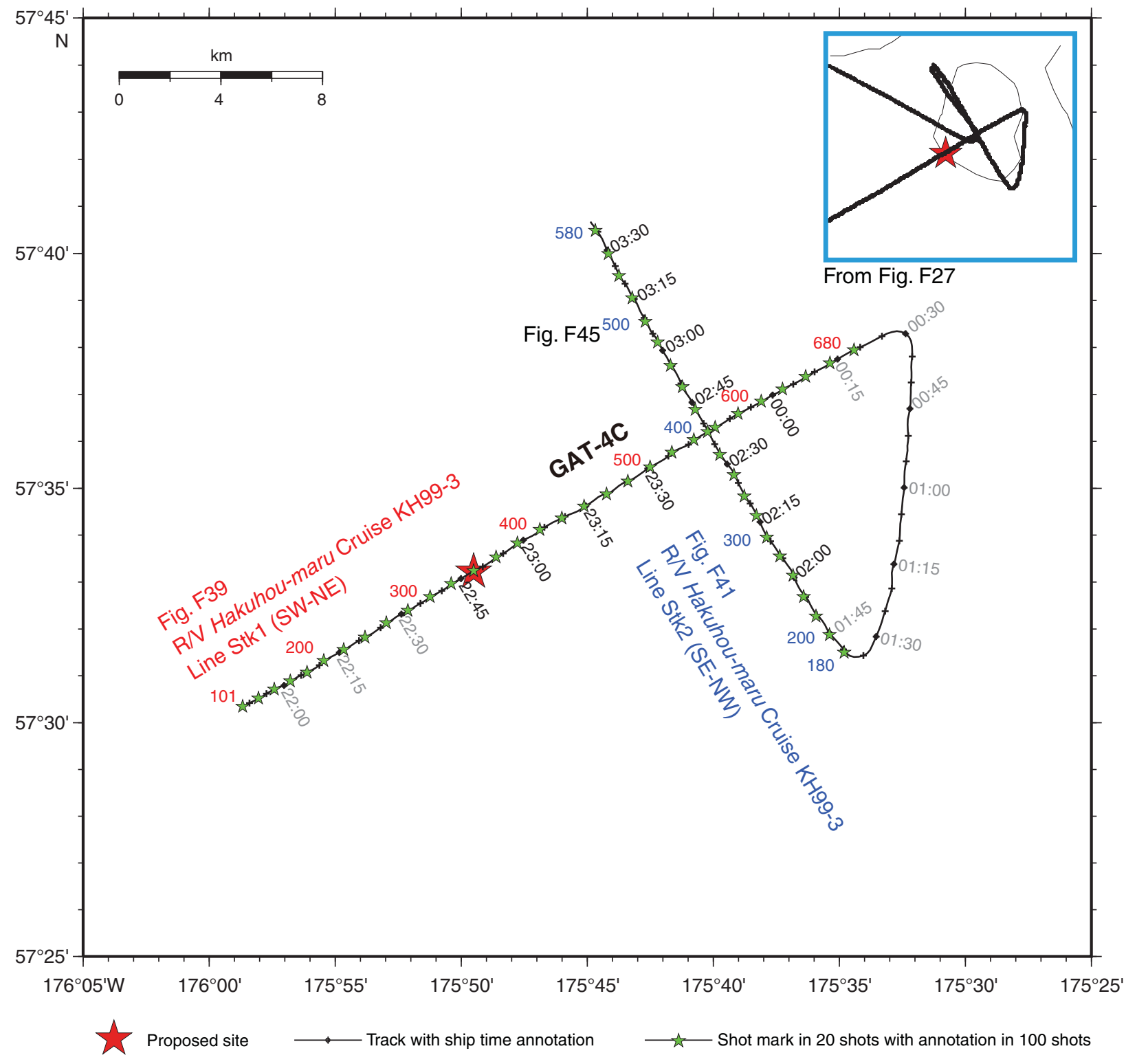


Figure F37. (A) Plain and (B) shaded relief swath bathymetric maps of Cruise KH99-03, Site GAT-4C.

A

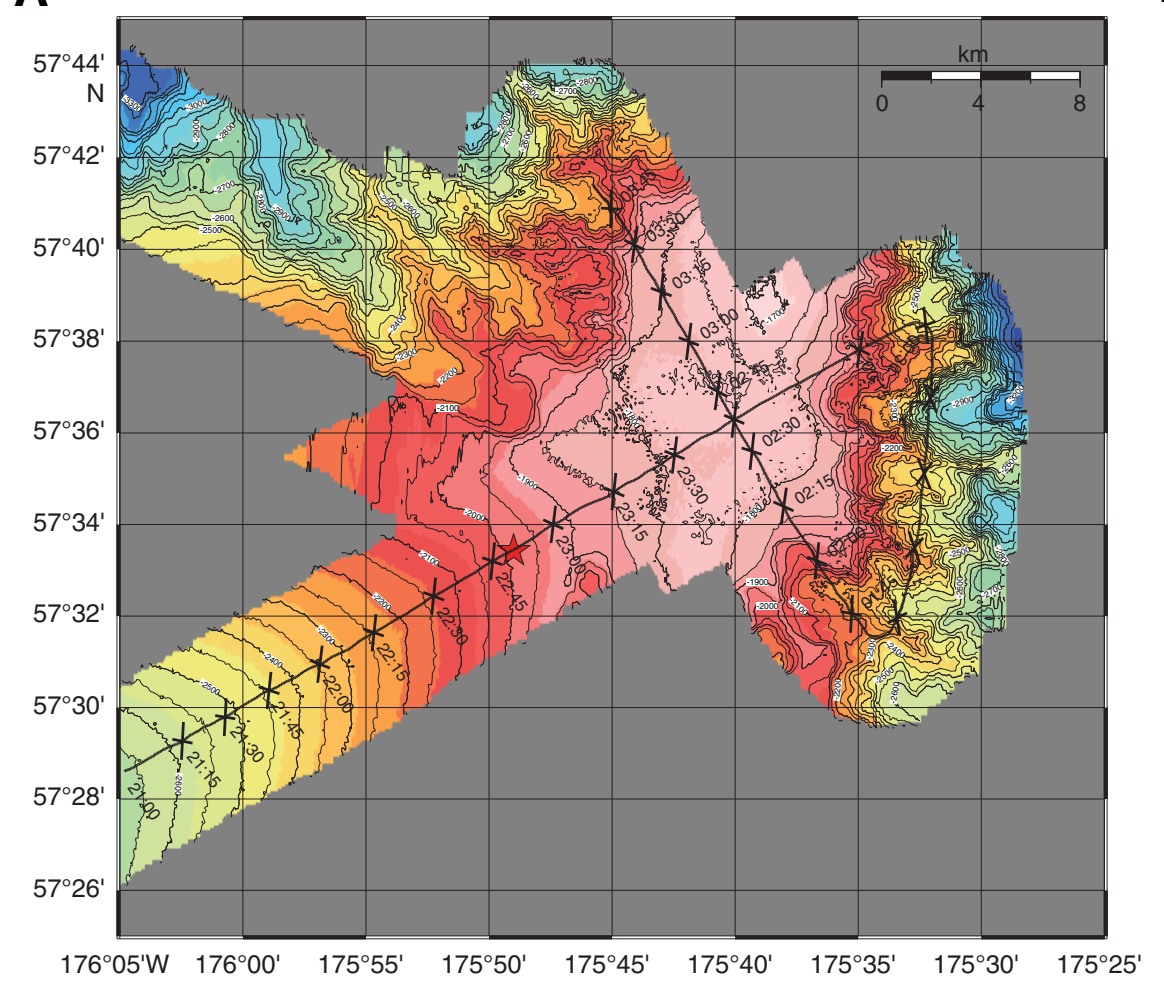

B

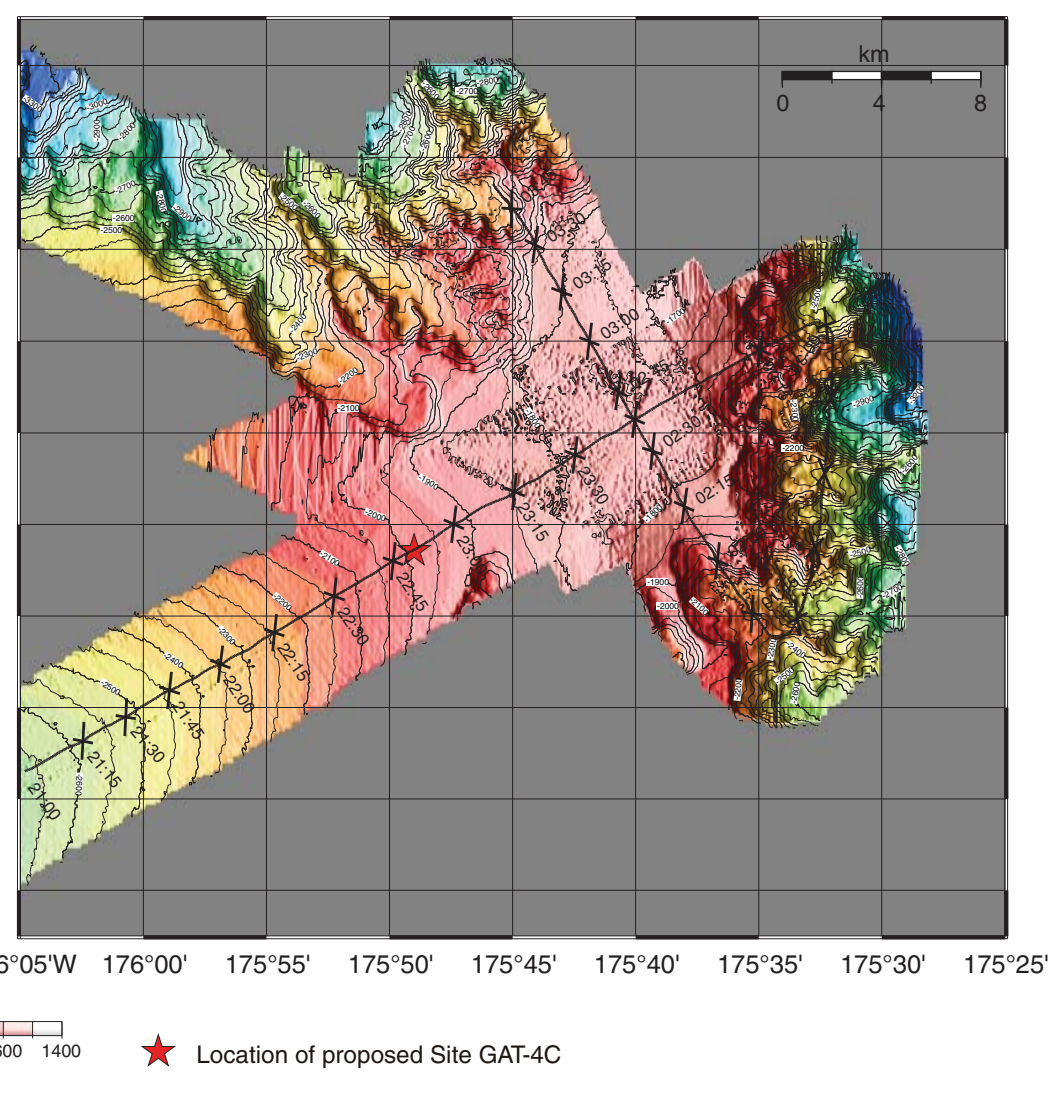

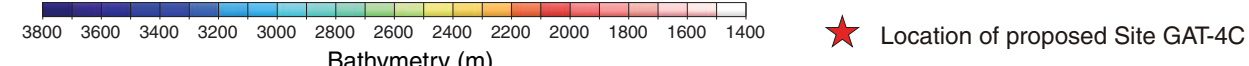


Figure F38. 3.5 kHz subbottom profiles of Cruise KH99-03, Site GAT-4C. A. Line Stk1 (southwest-northeast). B. Line Stk2 (southeast-northwest).
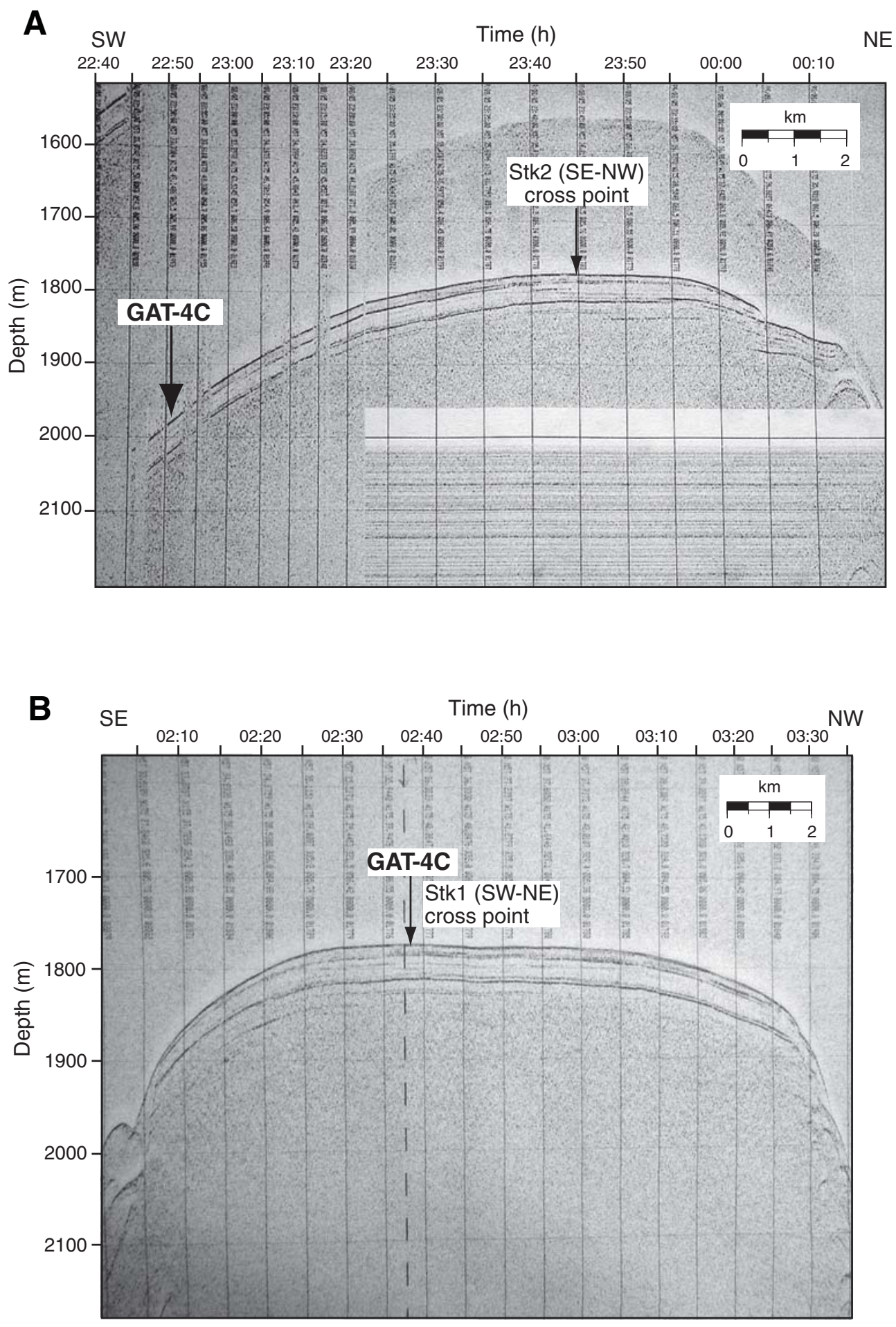
Figure F39. Seismic profile for Line Stk1 (southwest-northeast) from Cruise KH99-3, Site GAT-4C $\left(175^{\circ} 49.0^{\prime} \mathrm{W}, 57^{\circ} 33.4^{\prime} \mathrm{N}\right.$, Shotpoint 351 , water depth $=1975 \mathrm{mbsl}$, penetration depth = 700-745 mbsf).

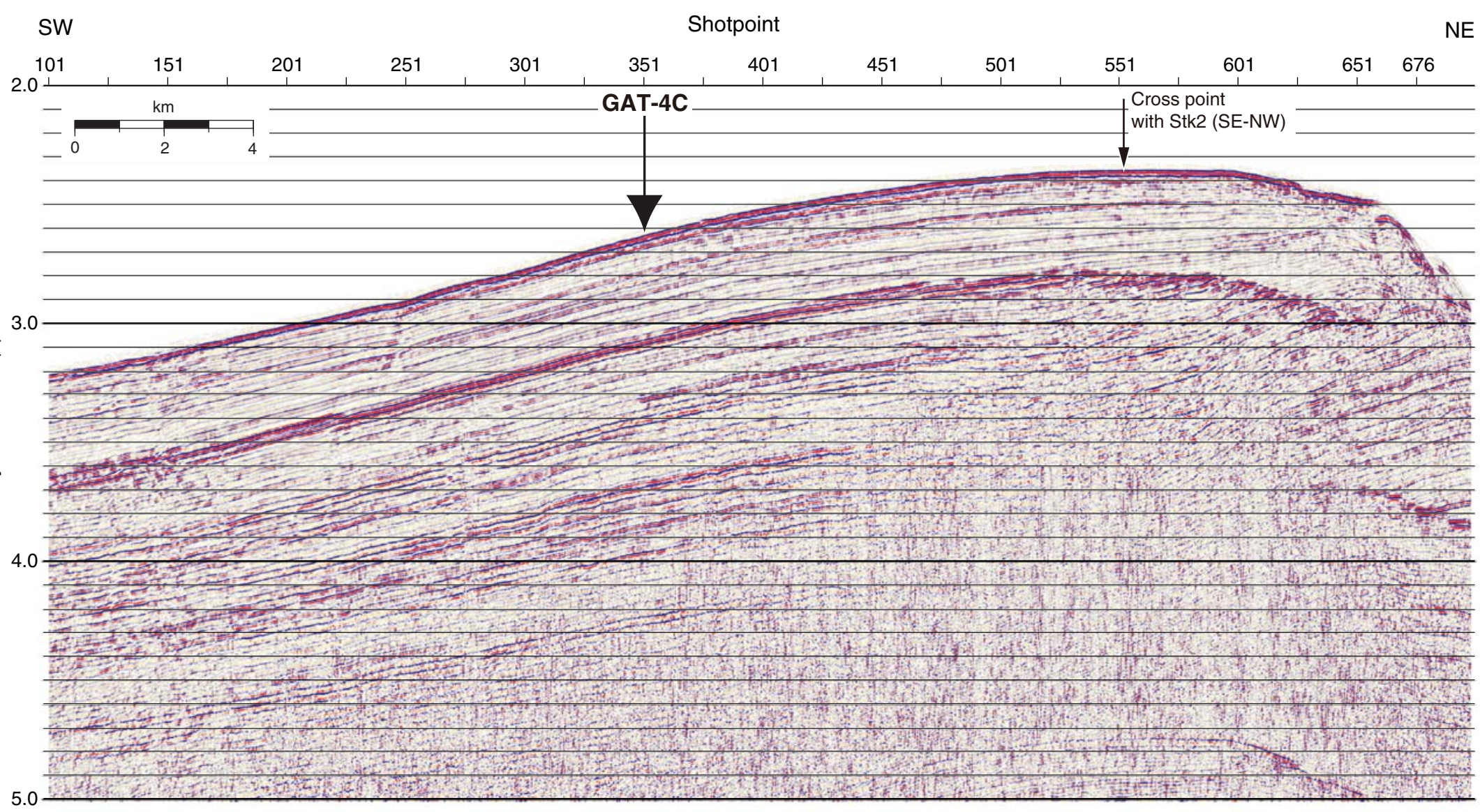


Figure F40. A. Close-up seismic profile for Line Stk1 (southwest-northeast) from Cruise KH99-3. Site GAT-4C. B. Time-depth curve estimated from results of velocity analyses on Lines Stk1 and Stk2.
A sw
$\begin{array}{lllllll}310 & 320 & 330 & 340 & 350 & 360 & 370\end{array}$
2.0

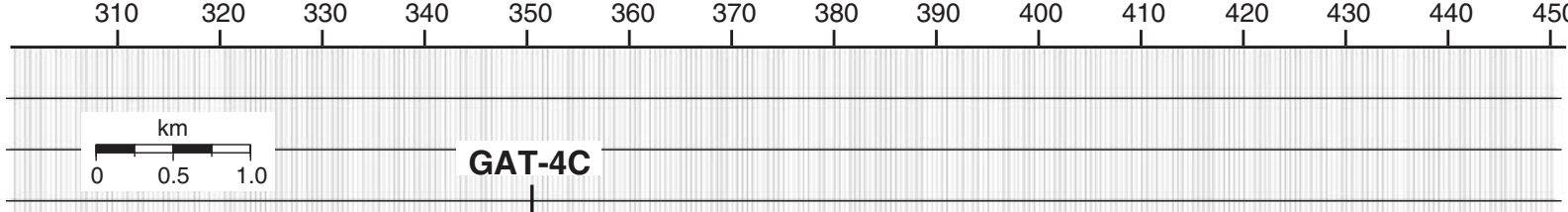

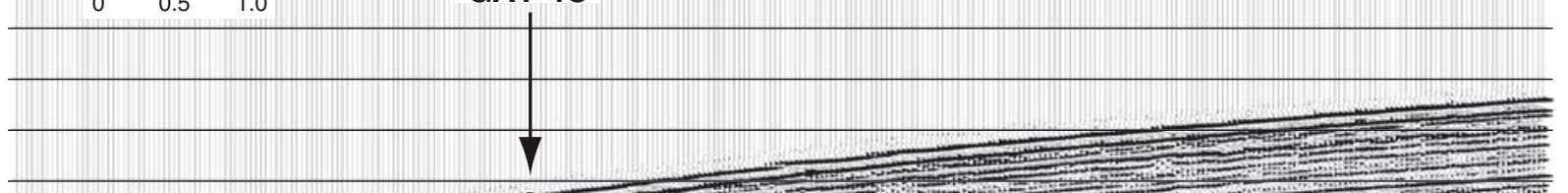

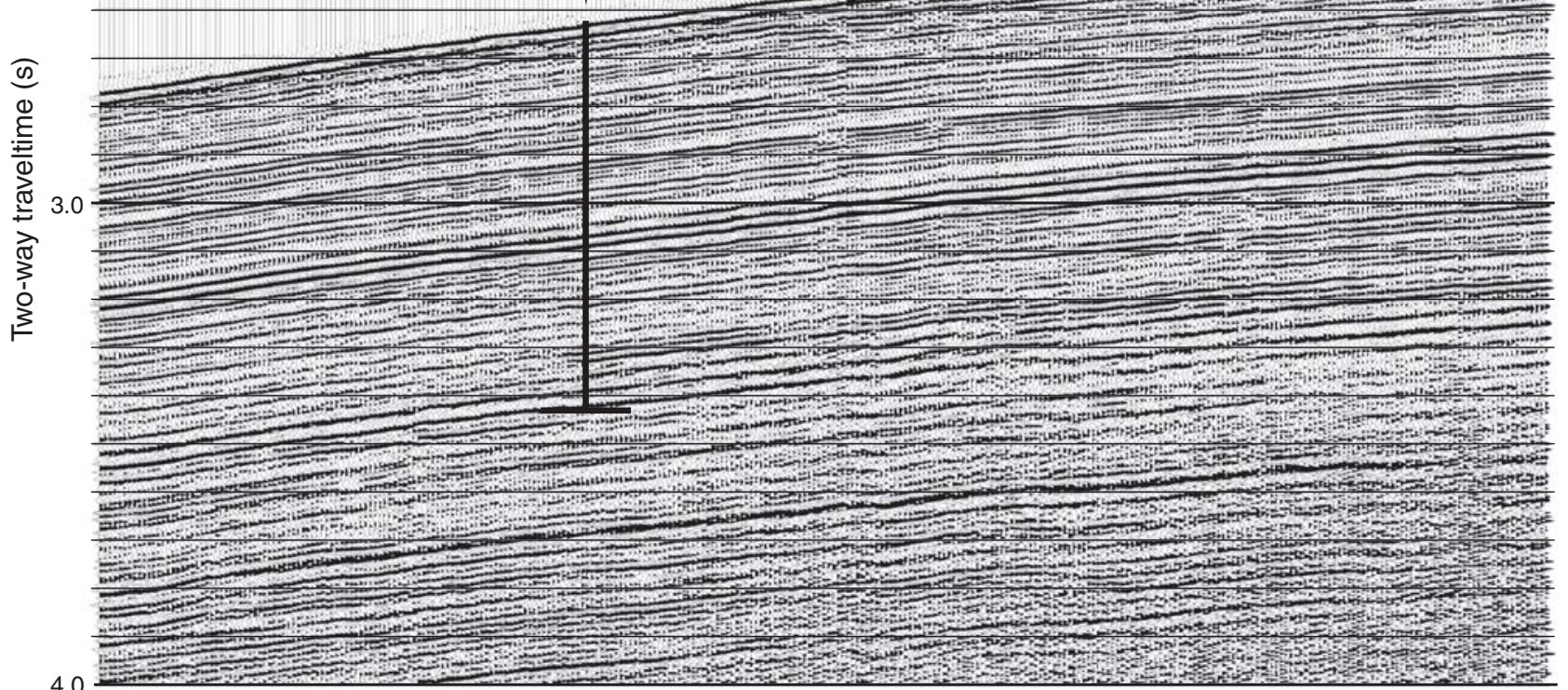

B Two-way traveltime below seafloor (s)

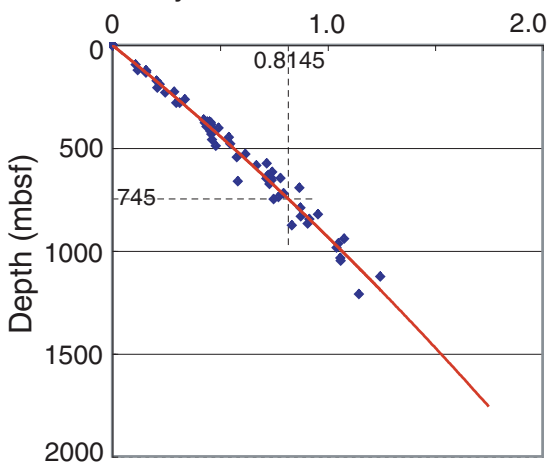


Figure F41. Seismic profile for Line Stk2 (southeast-northwest), Cruise KH99-3 for Site GAT-4C.

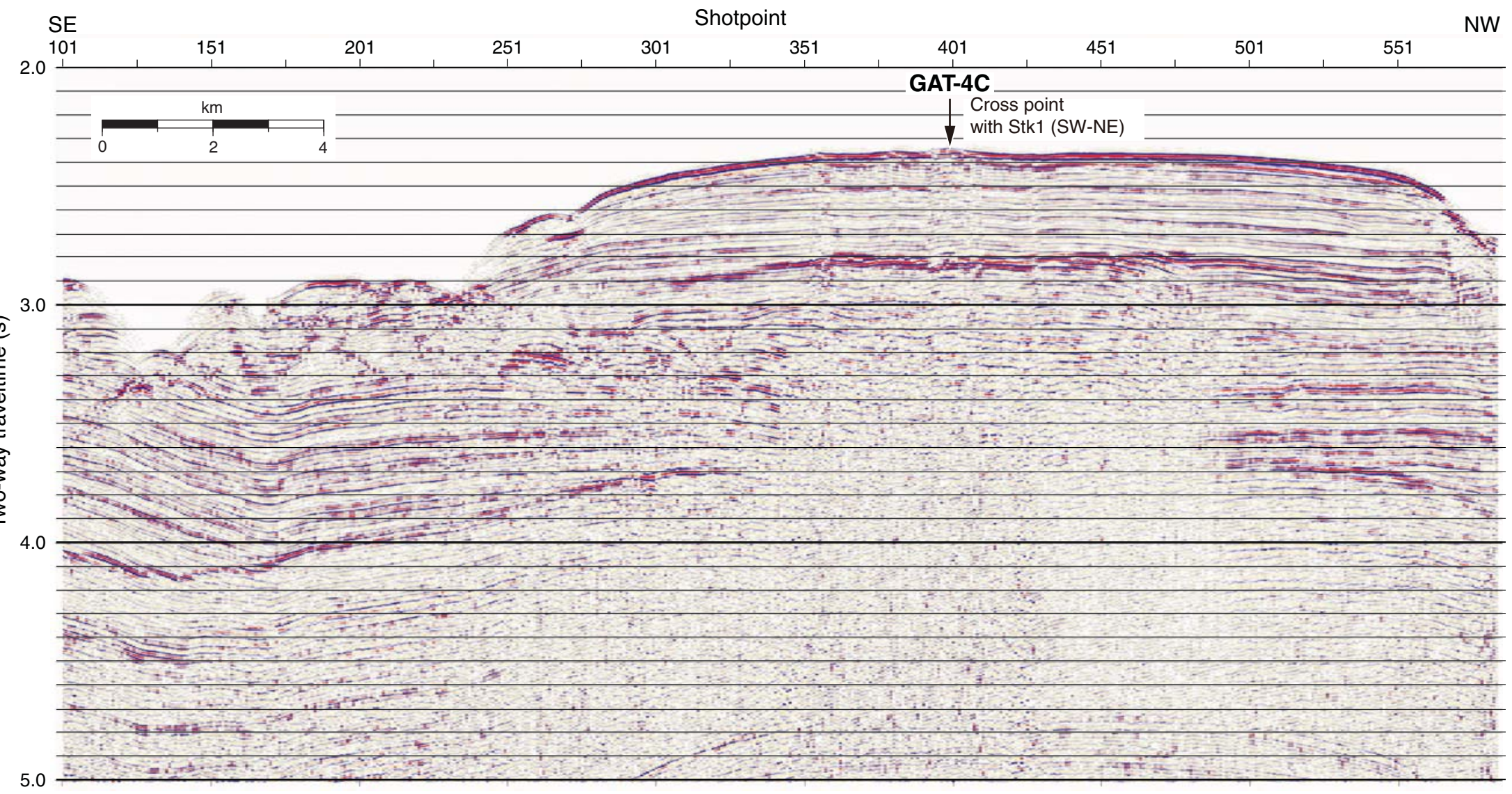


Figure F42. A. Close-up seismic profile for Line Stk2 (southeast-northwest) from Cruise KH99-3, Site GAT-4C. B. Time-depth curve estimated from results of velocity analyses on Lines Stk1 and Stk2.

A SE Shotpoint $\quad$ NW
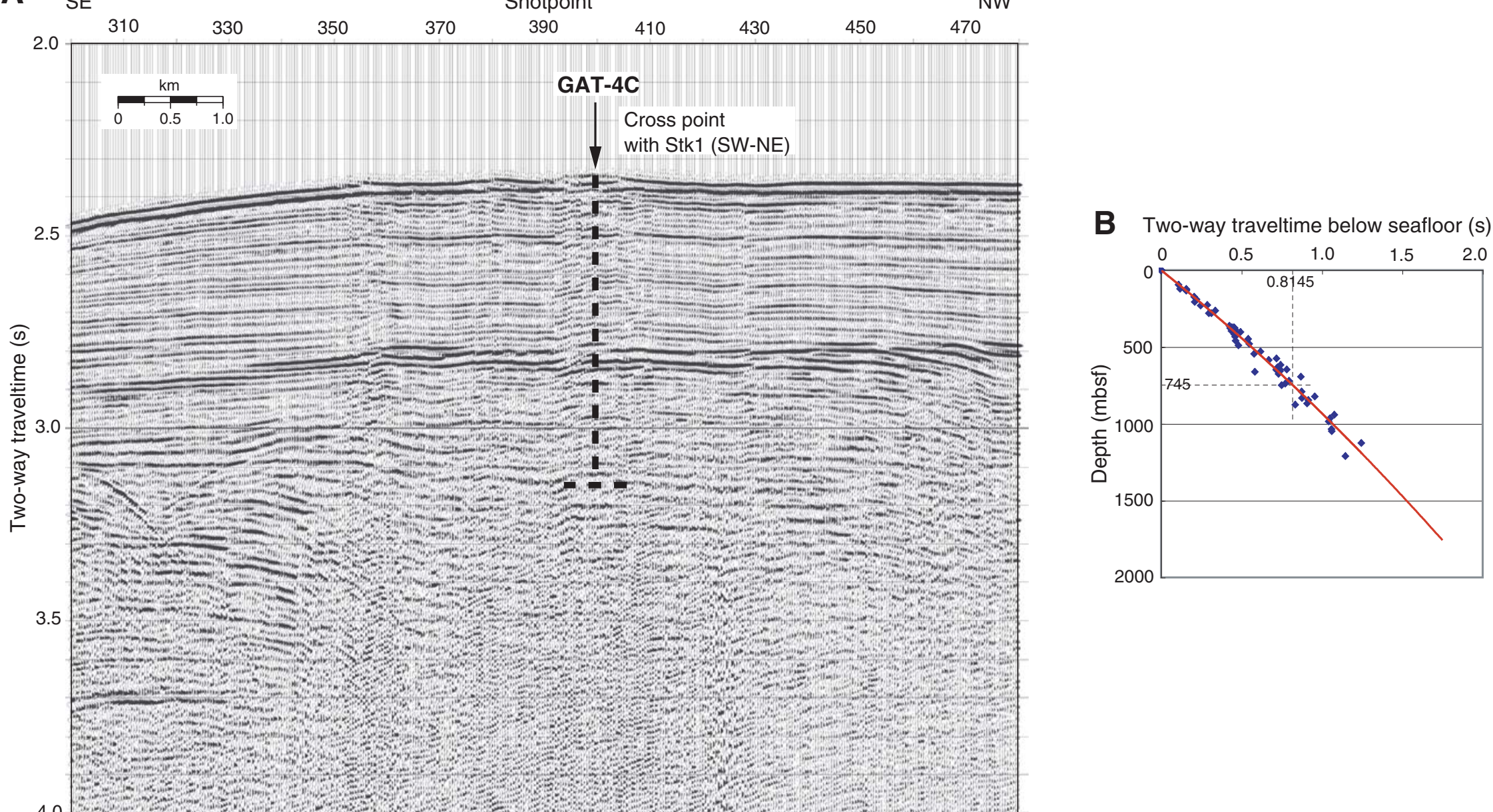

4.0

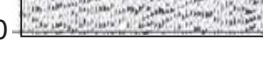


Figure F43. Seismic profile with potential hazards (bottom-simulating reflector [BSR] annotation), Site GAT-4C

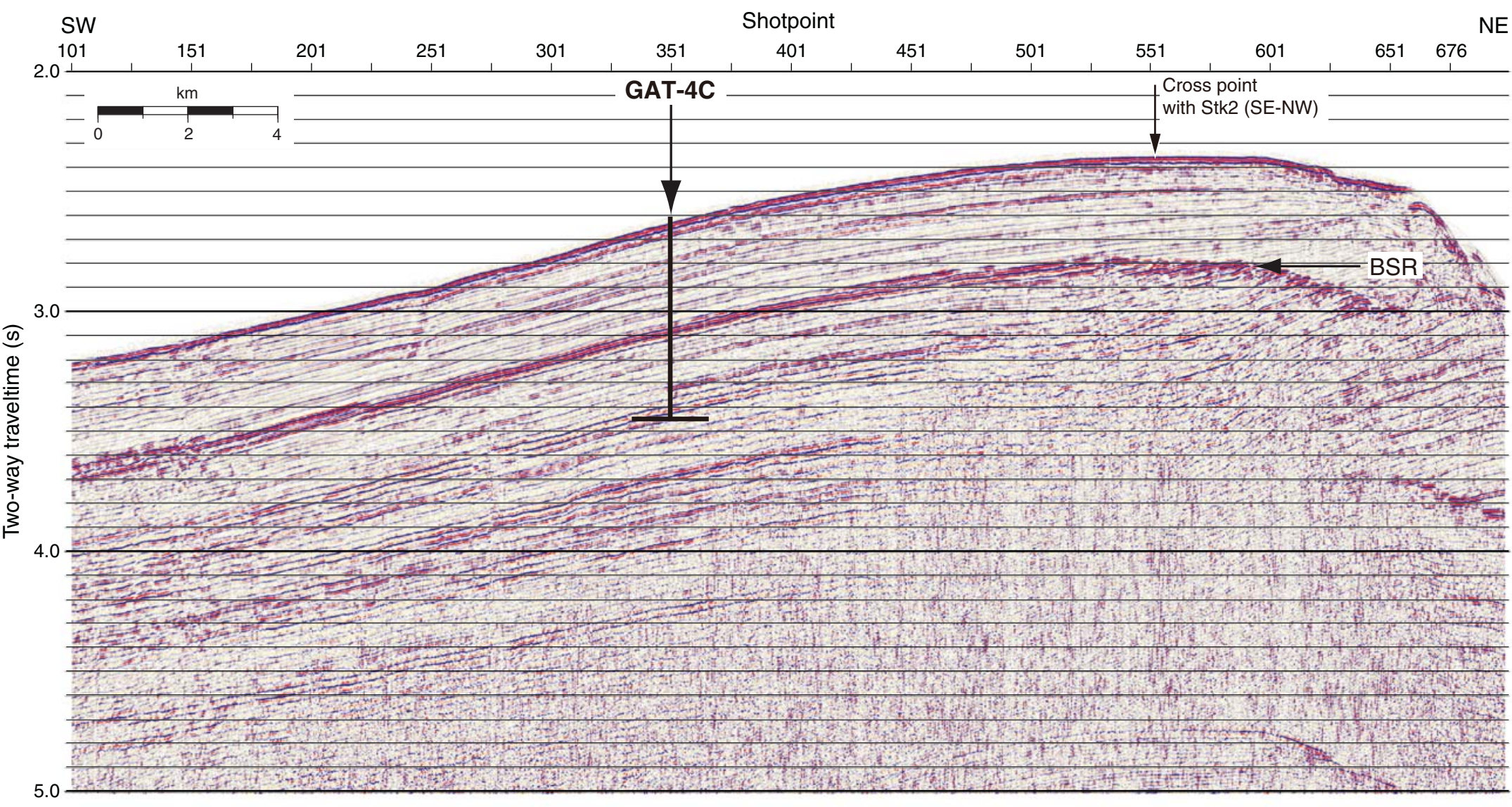


Figure F44. Regional overview map of the Umnak Plateau sites with tracks of Cruise L6-80.

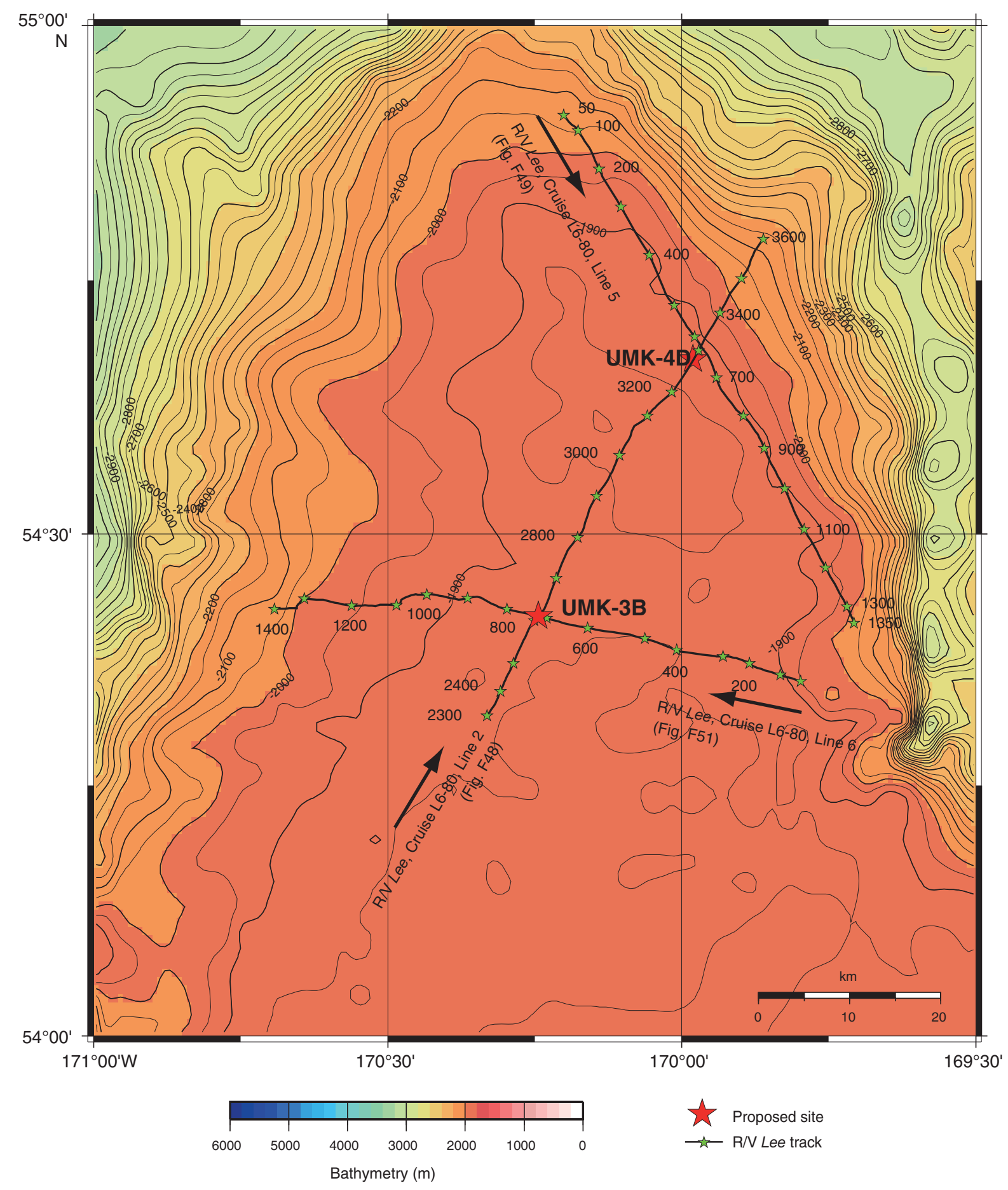


Figure F45. Regional overview map of the Umnak Plateau sites with tracks of Cruise KH99-3.

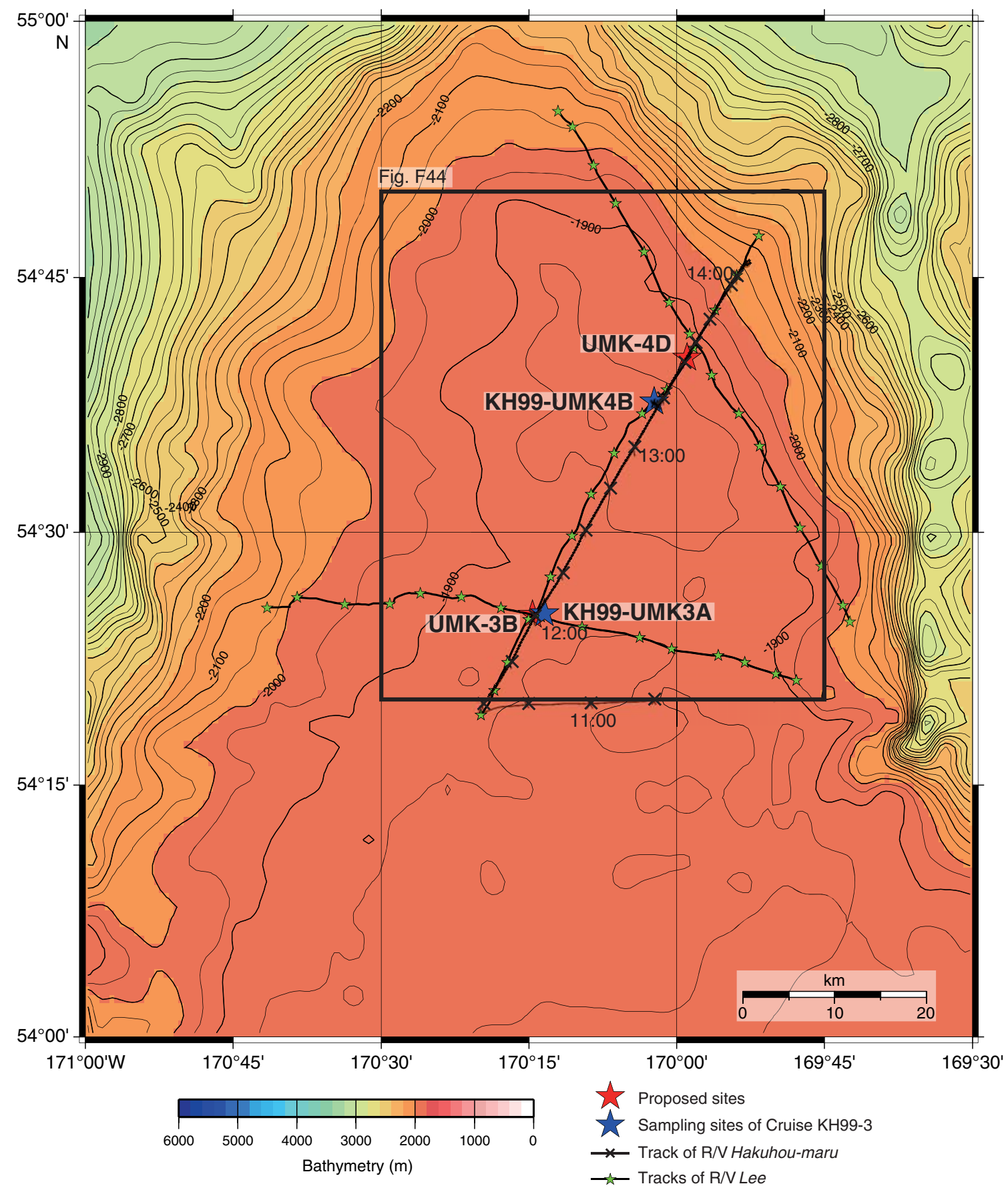




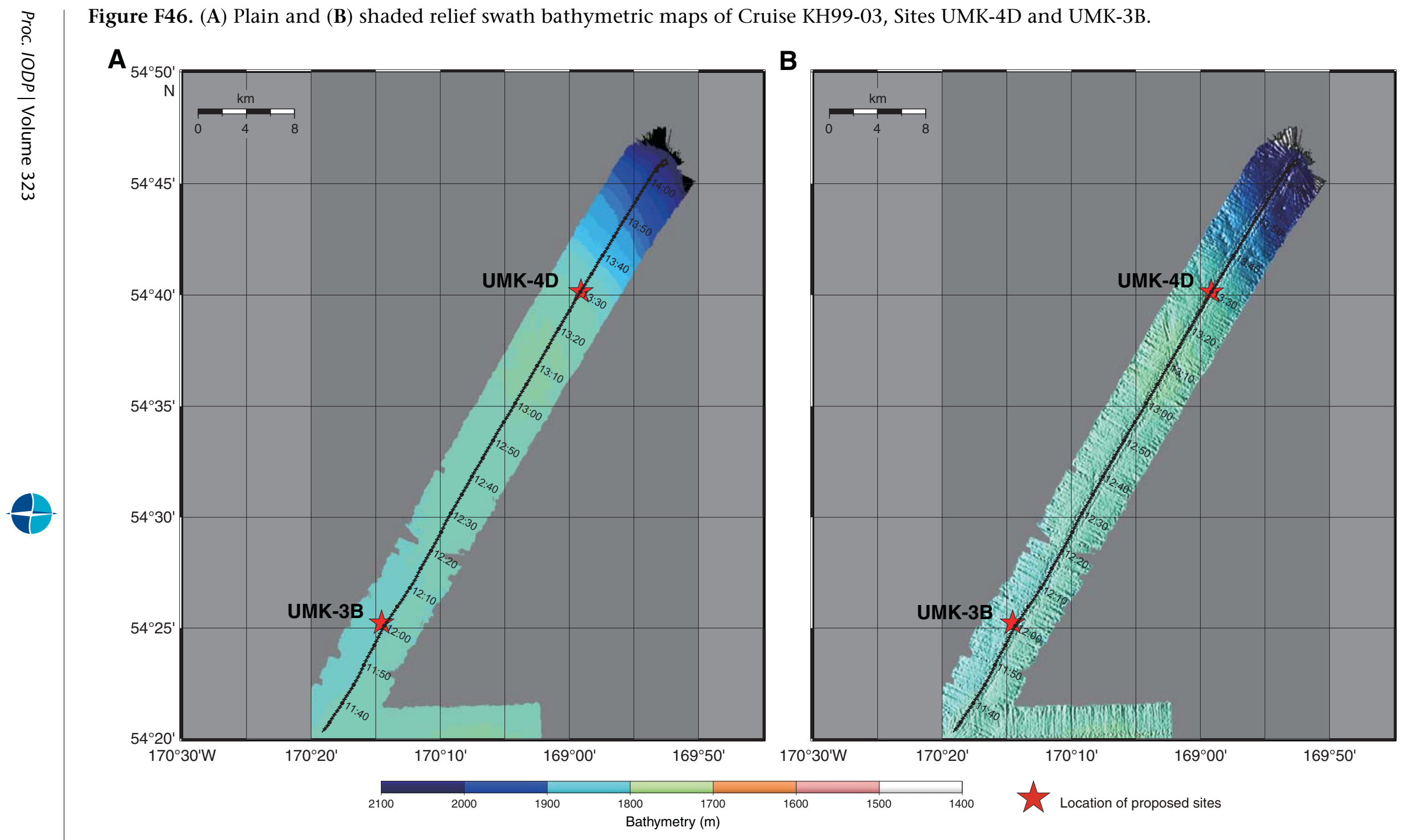




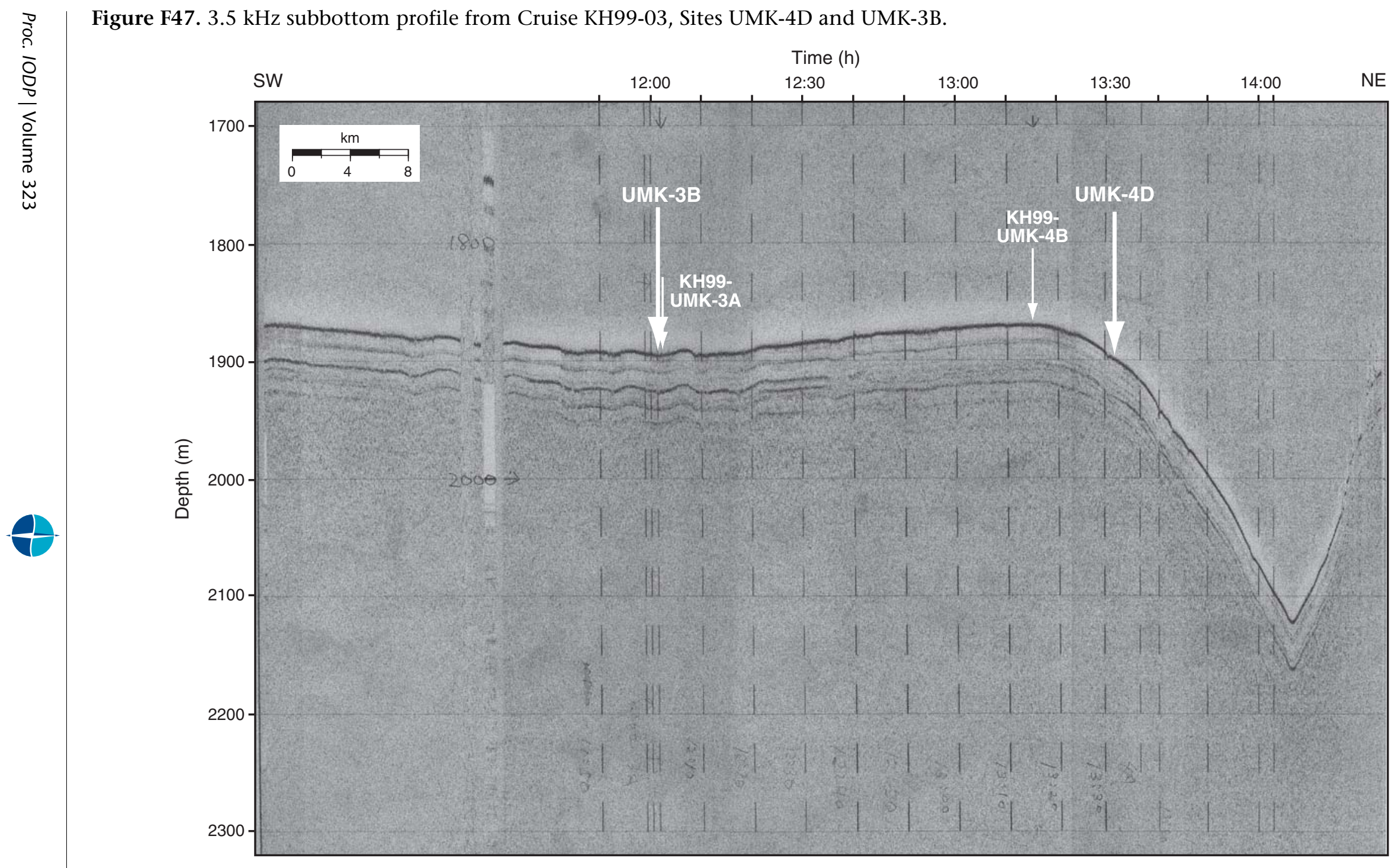


Figure F48. Seismic profile for Line 2 from Cruise L6-80, Sites UMK-4D and UMK-3B. CDP = common depth point.

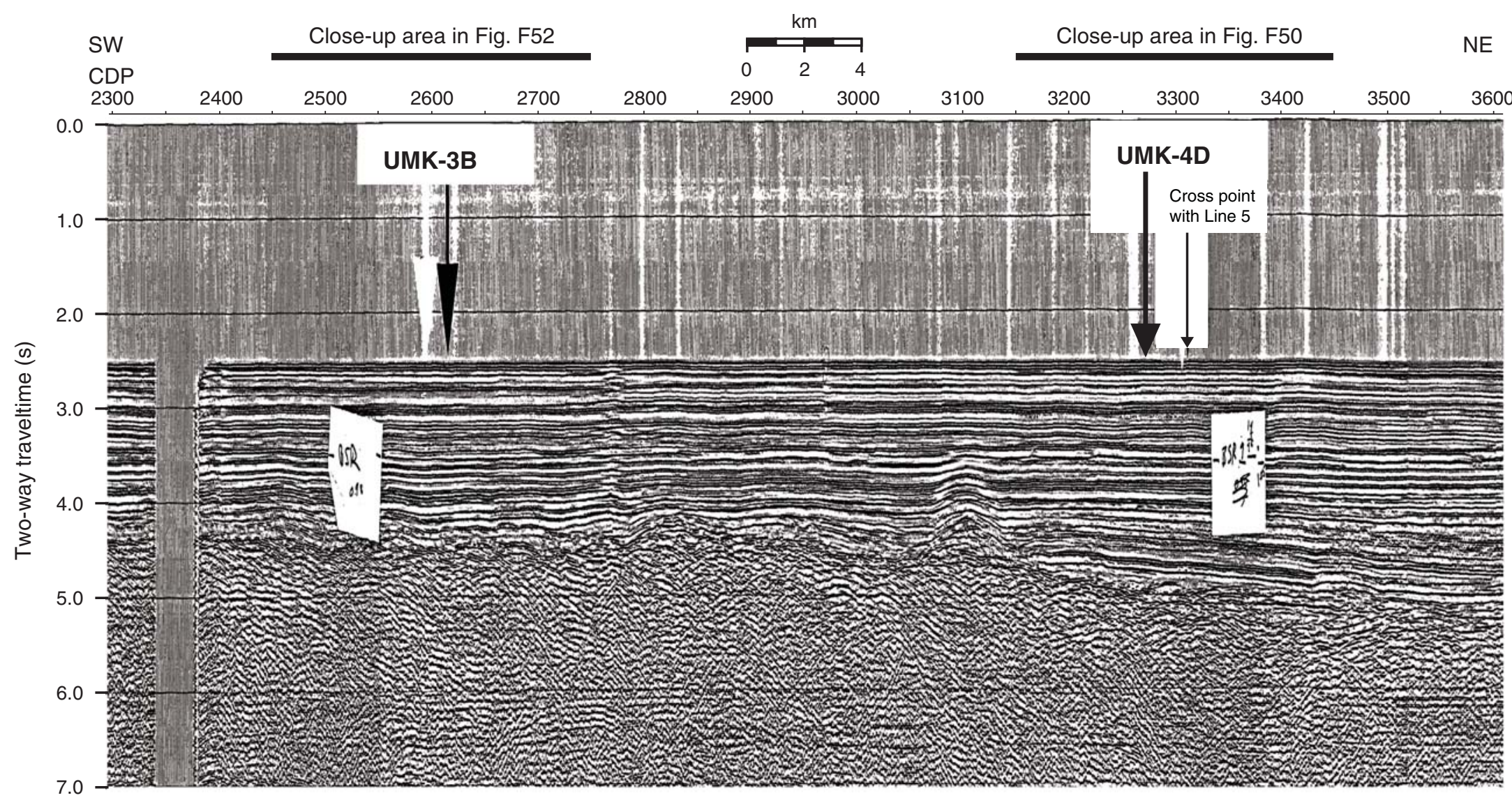



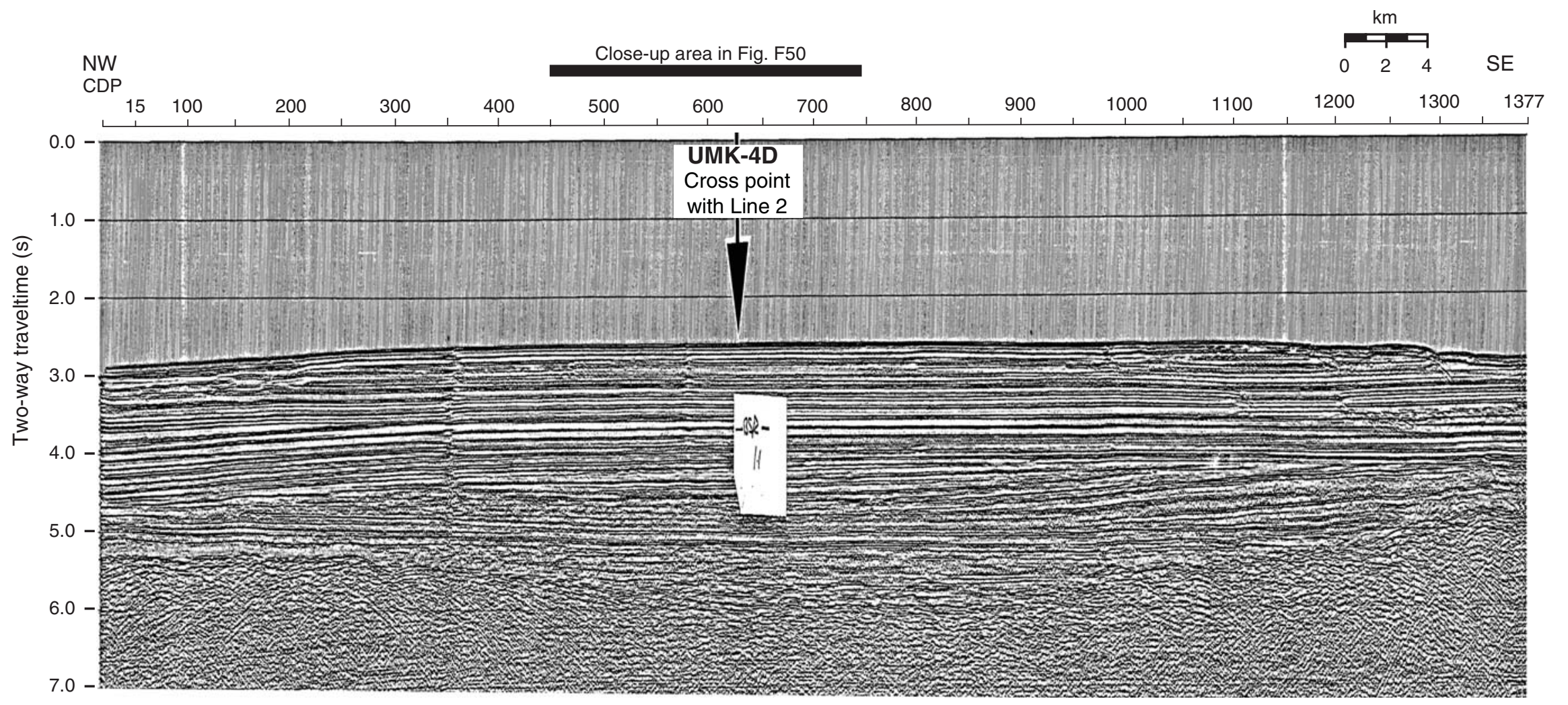
Figure F50. Close-up seismic profile for Lines 2 and 5 from Cruise L6-80, Site UMK-4D. CDP = common depth point.
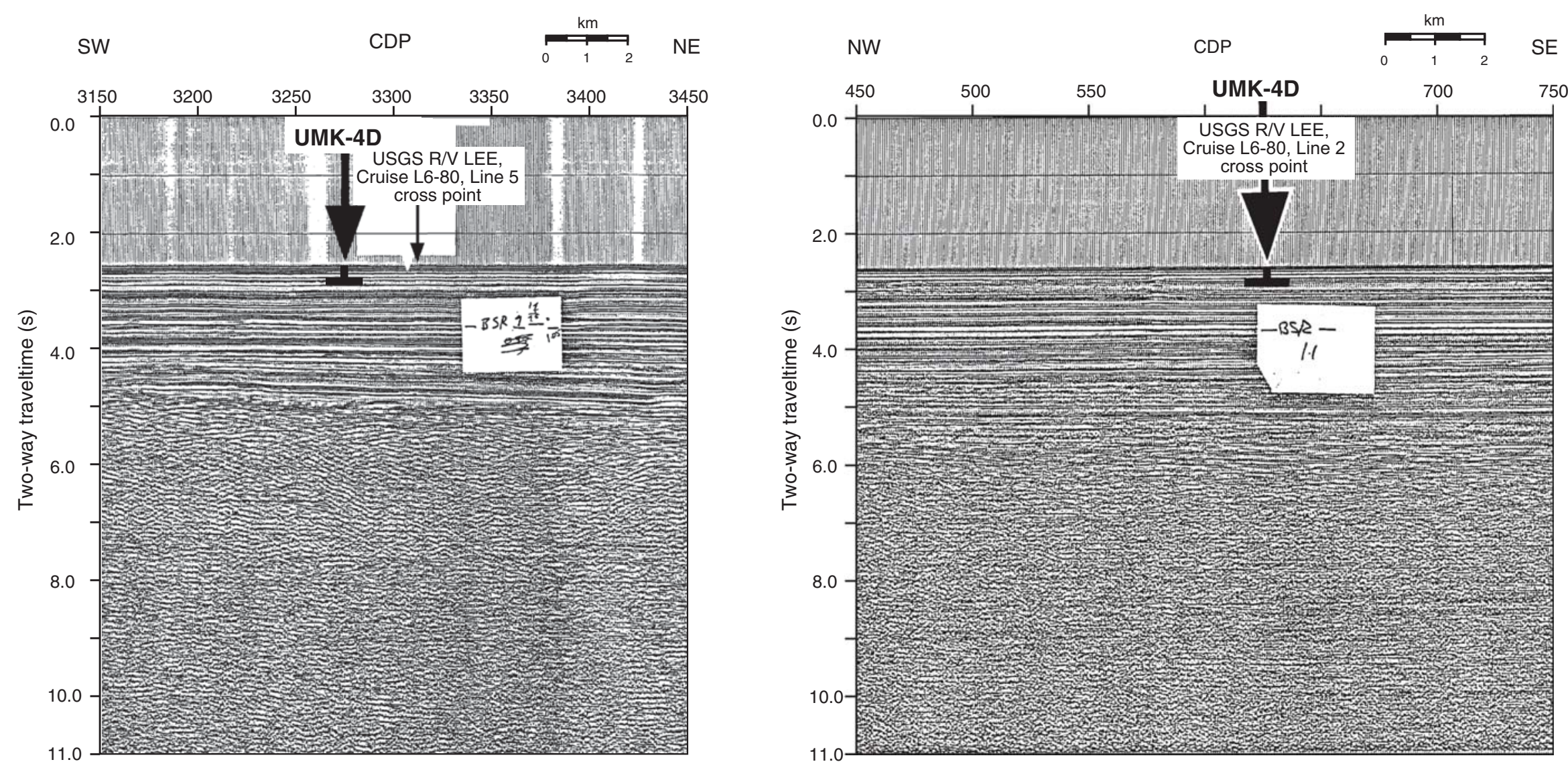
Figure F51. Seismic profile for Line 6 from Cruise L6-80, Site UMK-3B. CDP = common depth point.

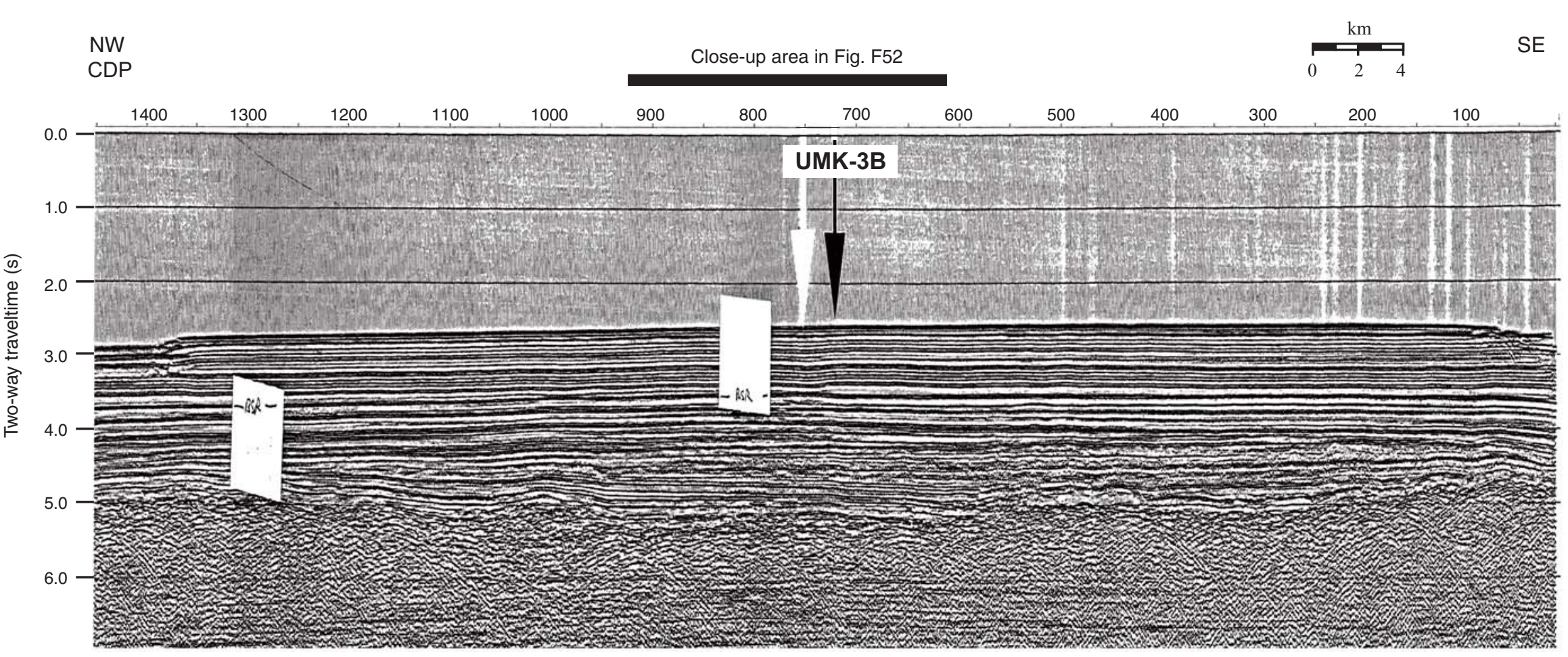



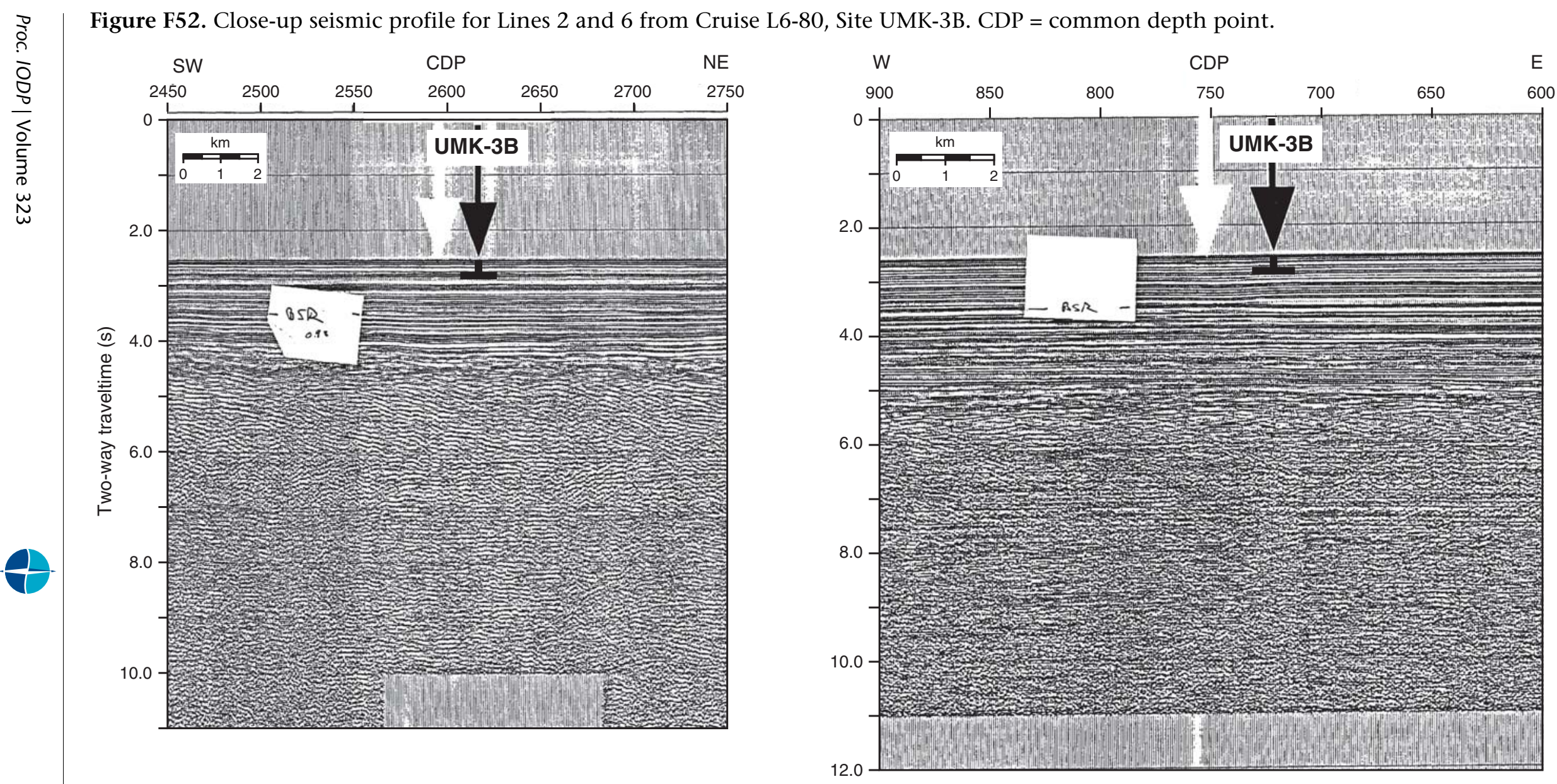
Figure F53. Seismic profiles with potential hazards (bottom-simulating reflector $[\mathrm{BSR}]$ annotation) for the Umnak Plateau sites. CDP $=$ common depth point. A. Line 6. B. Line 2.

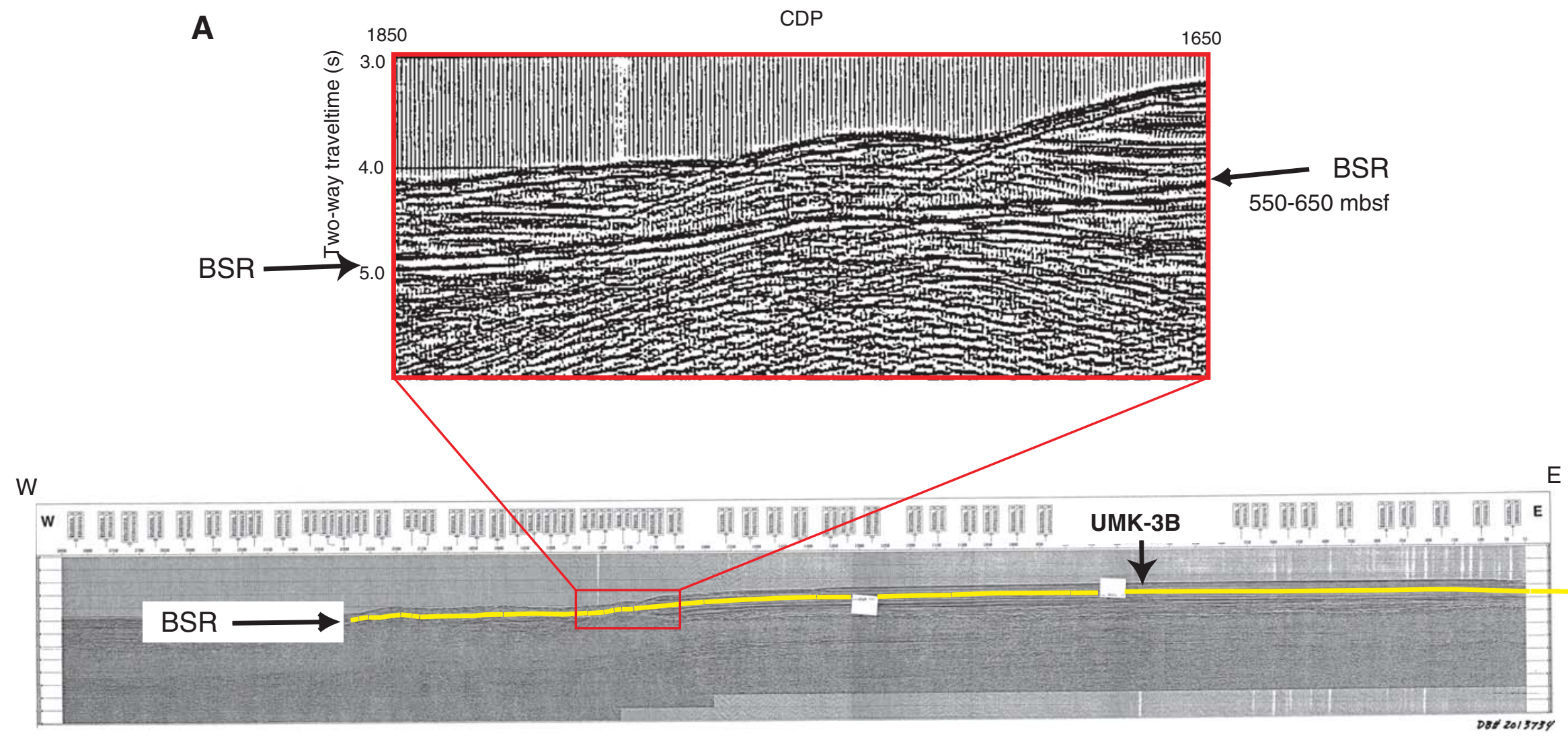

B

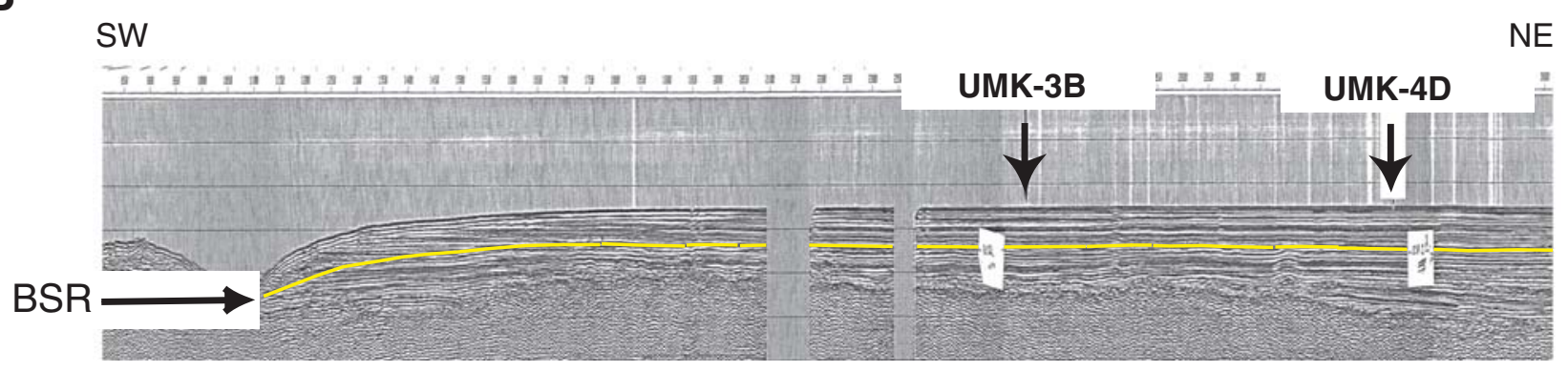


Figure F54. Interval velocity analyses from Cruise L6-80. A low-velocity zone was detected immediately beneath the bottom-simulating reflectors (BSRs), suggesting the existence of gas hydrate. A. Line 6 at Site UMK4D. B. Line 5 at Site UMK-3B.
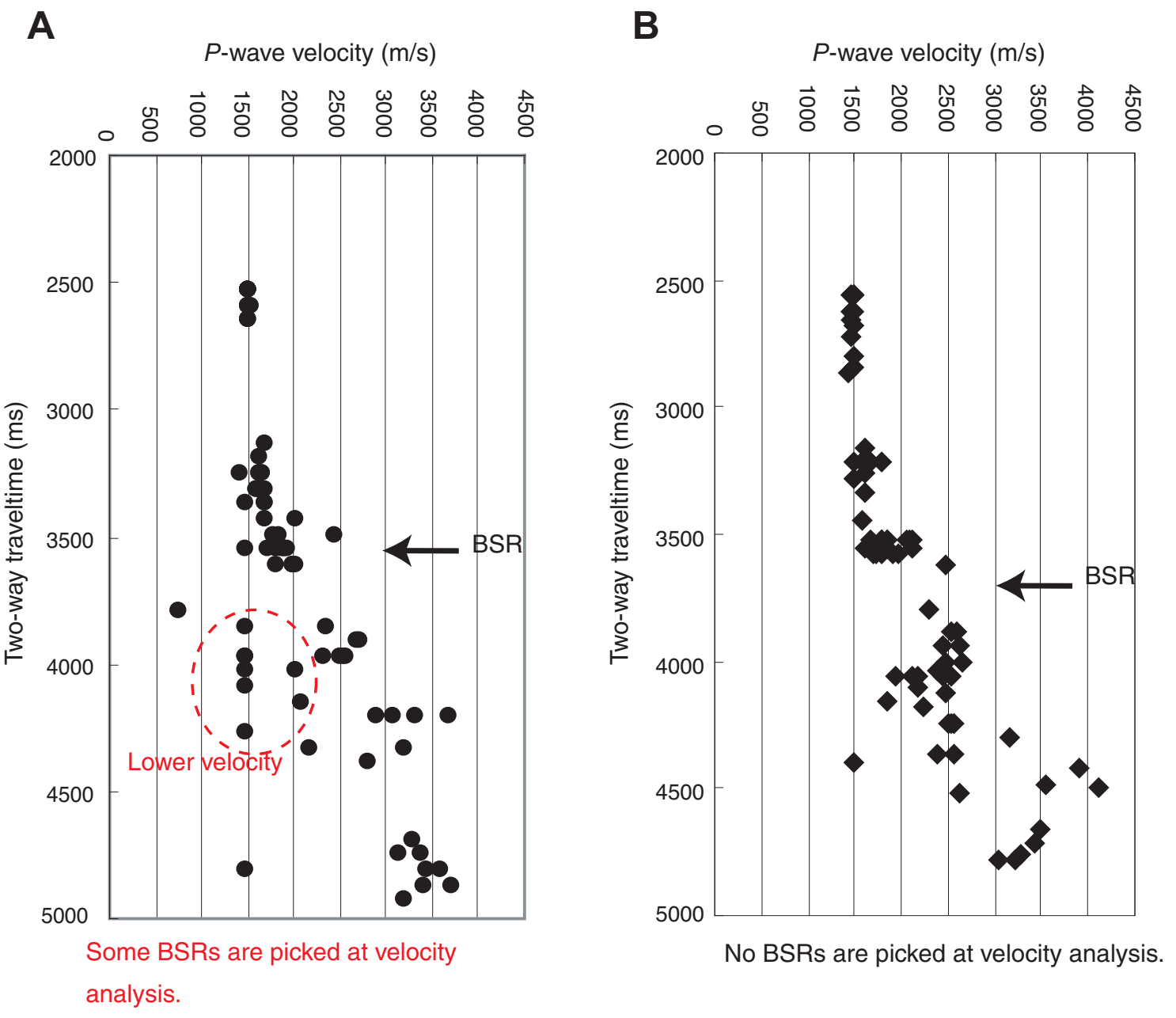


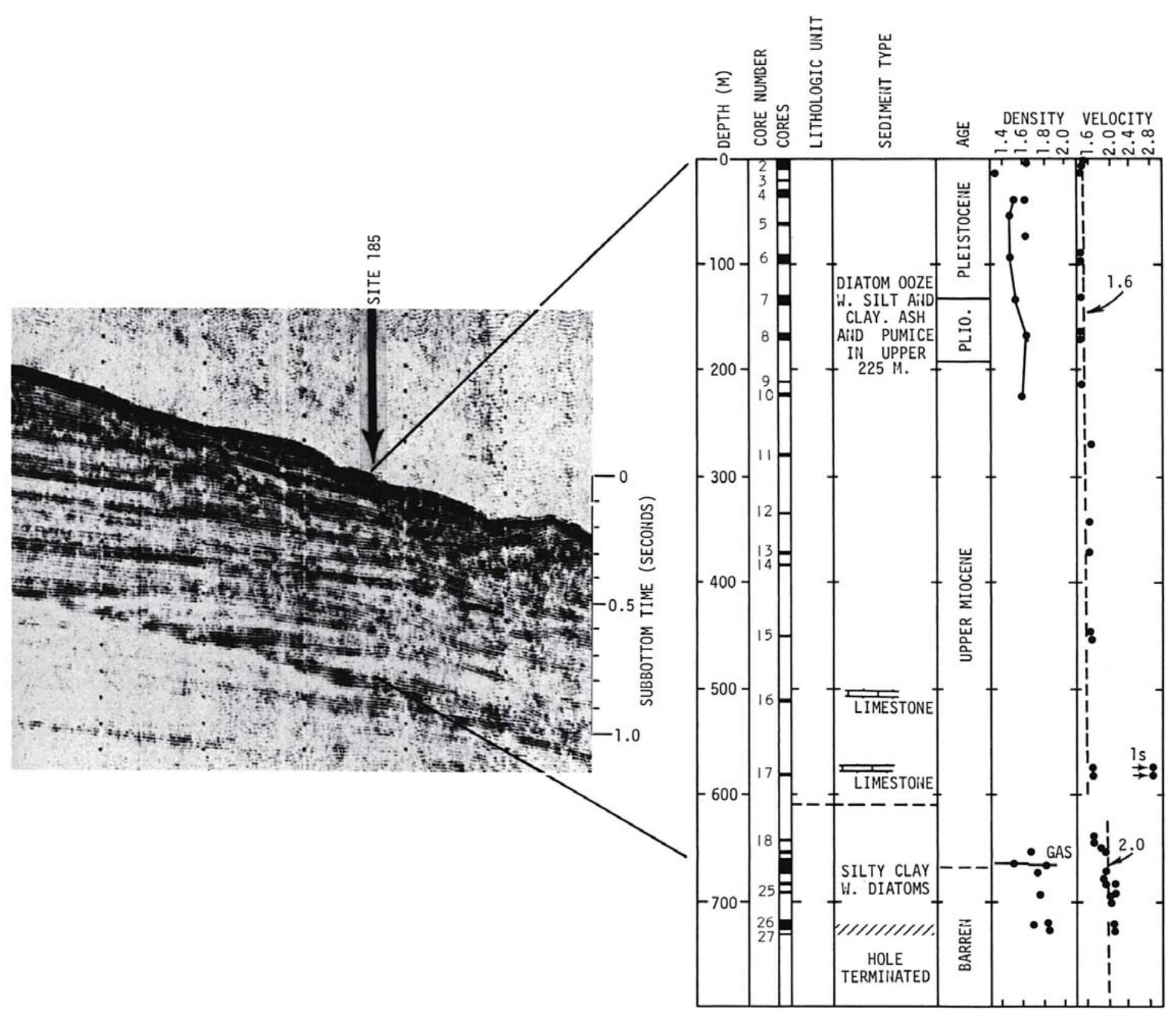


Figure F56. Regional overview map of Shirshov Ridge sites, Expedition 323.

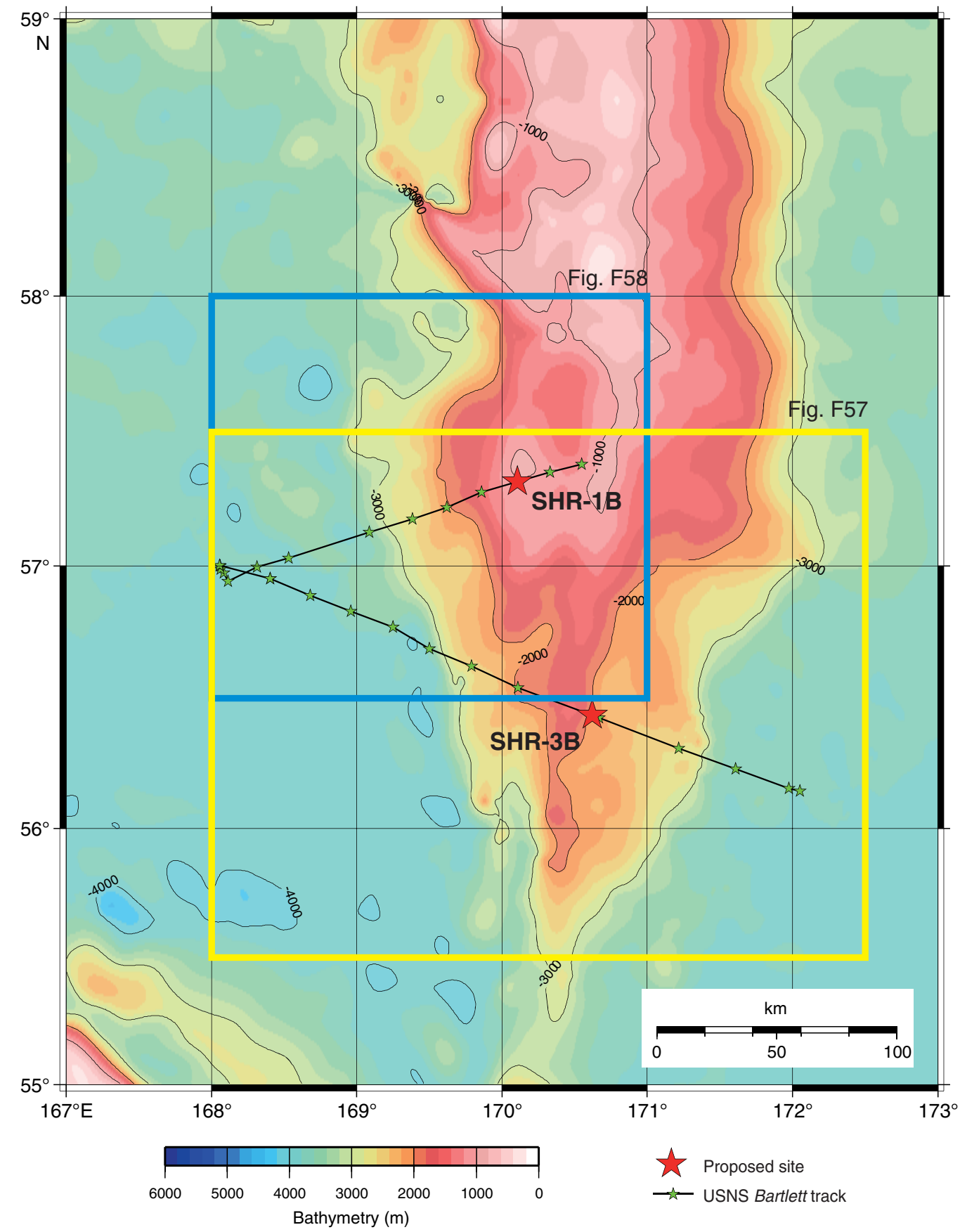


Figure F57. Map of study area, Site SHR-3B.

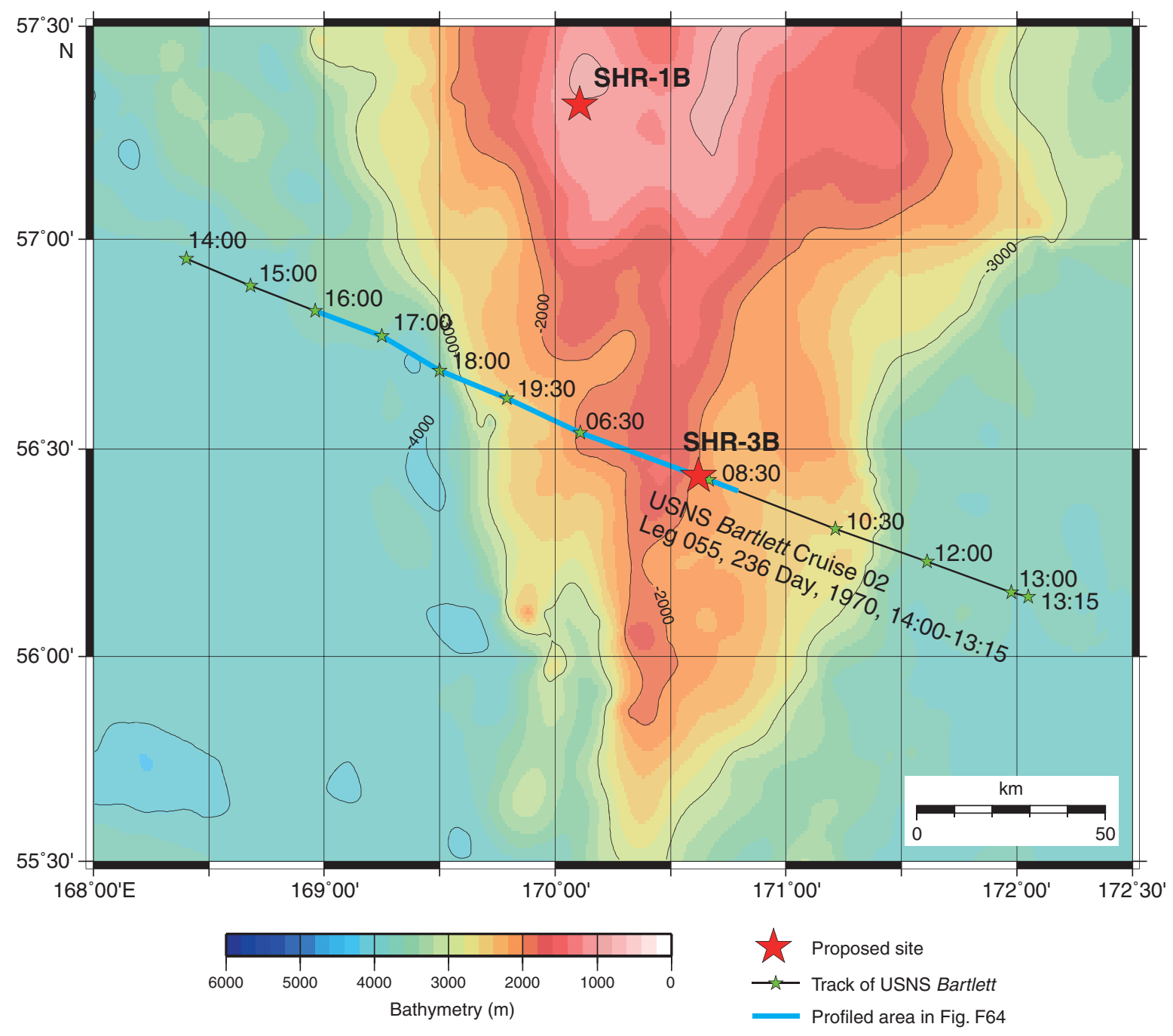


Figure F58. Map of study area, Site SHR-1B.

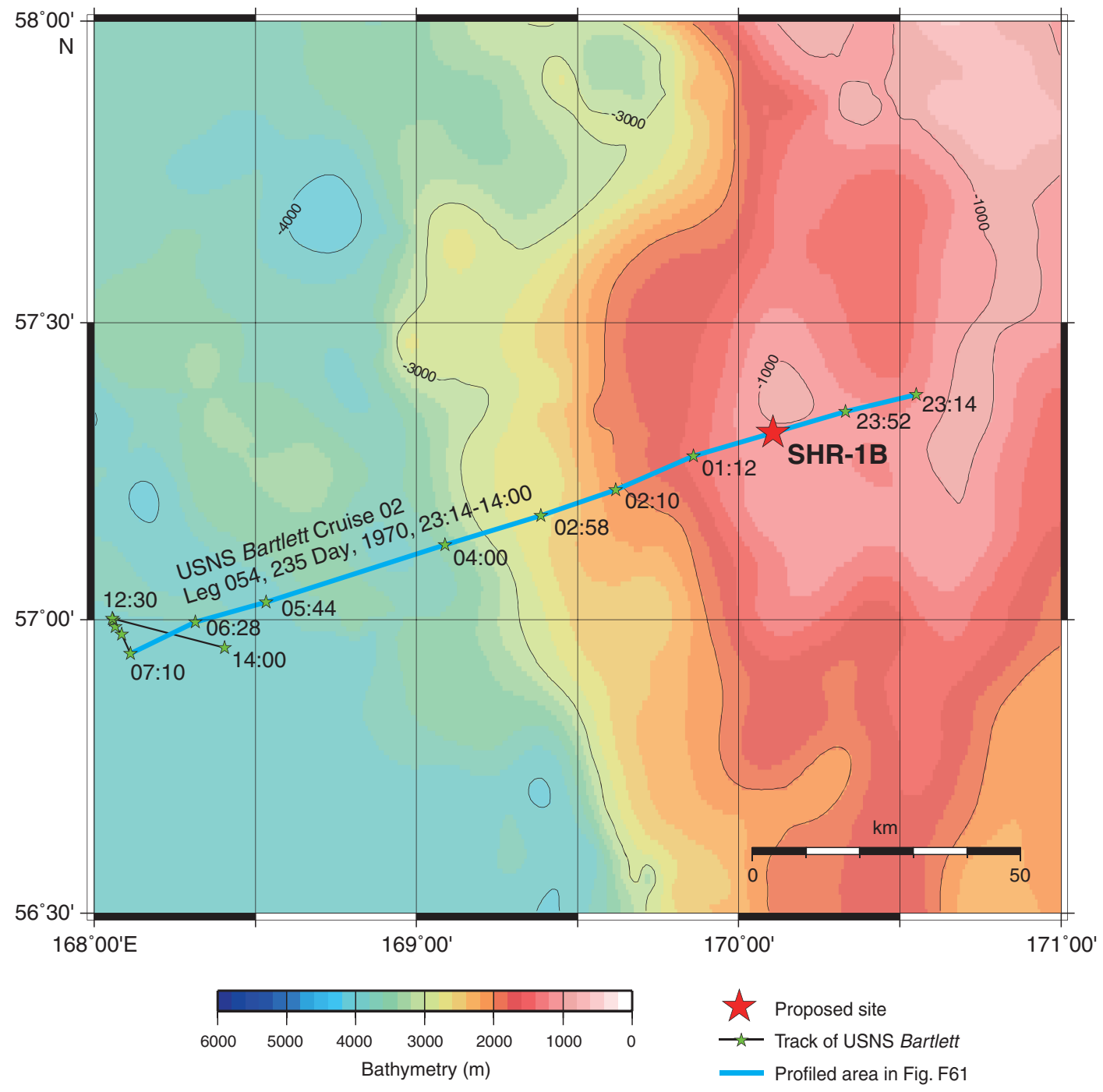


Figure F59. Seismic profile from Leg 055, Cruise 02, Site SHR-3B.

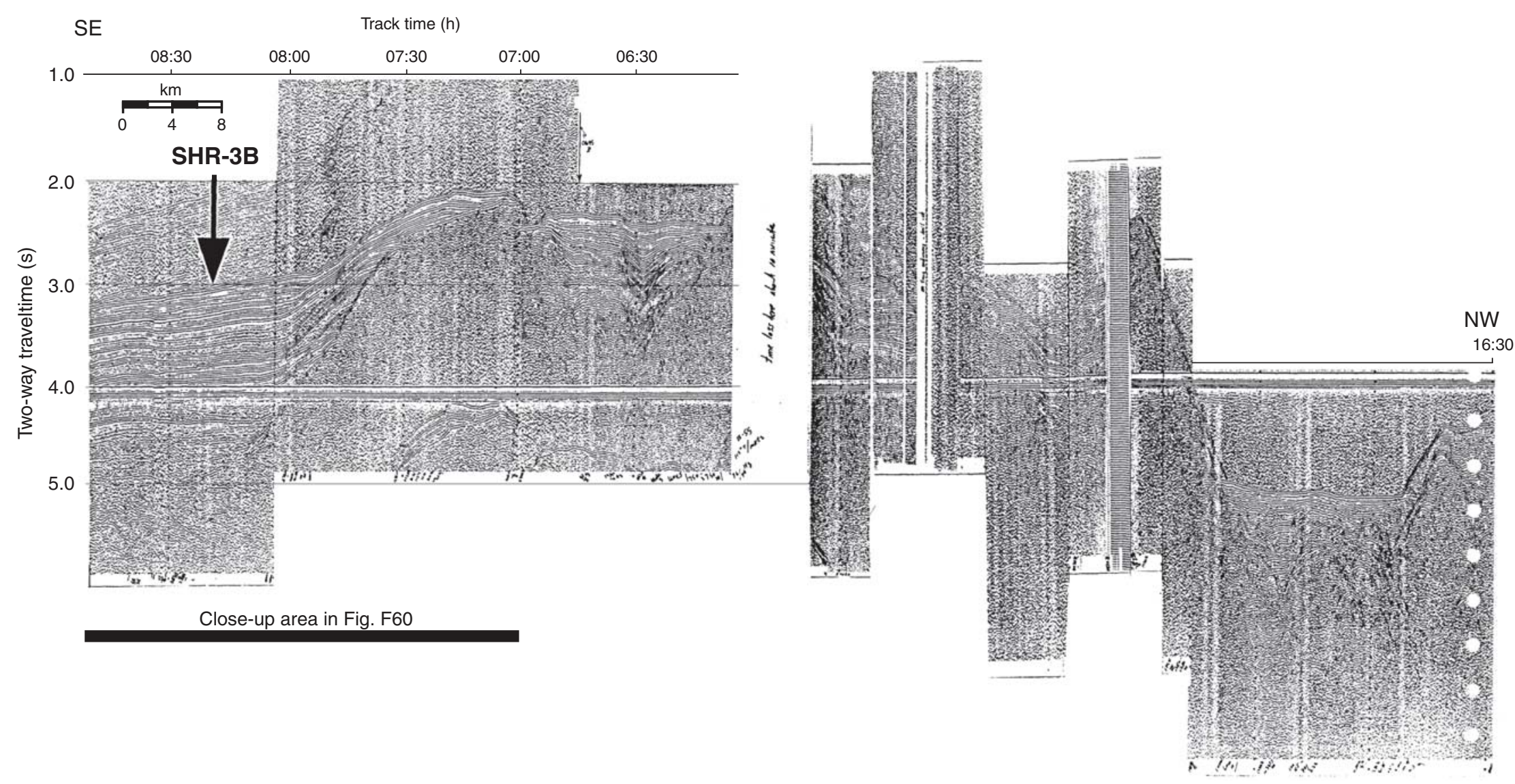


Figure F60. A. Close-up seismic profile from Leg 055, Cruise 02, Site SHR-3B. B. Time-depth conversion curve used for Site SHR-3B.

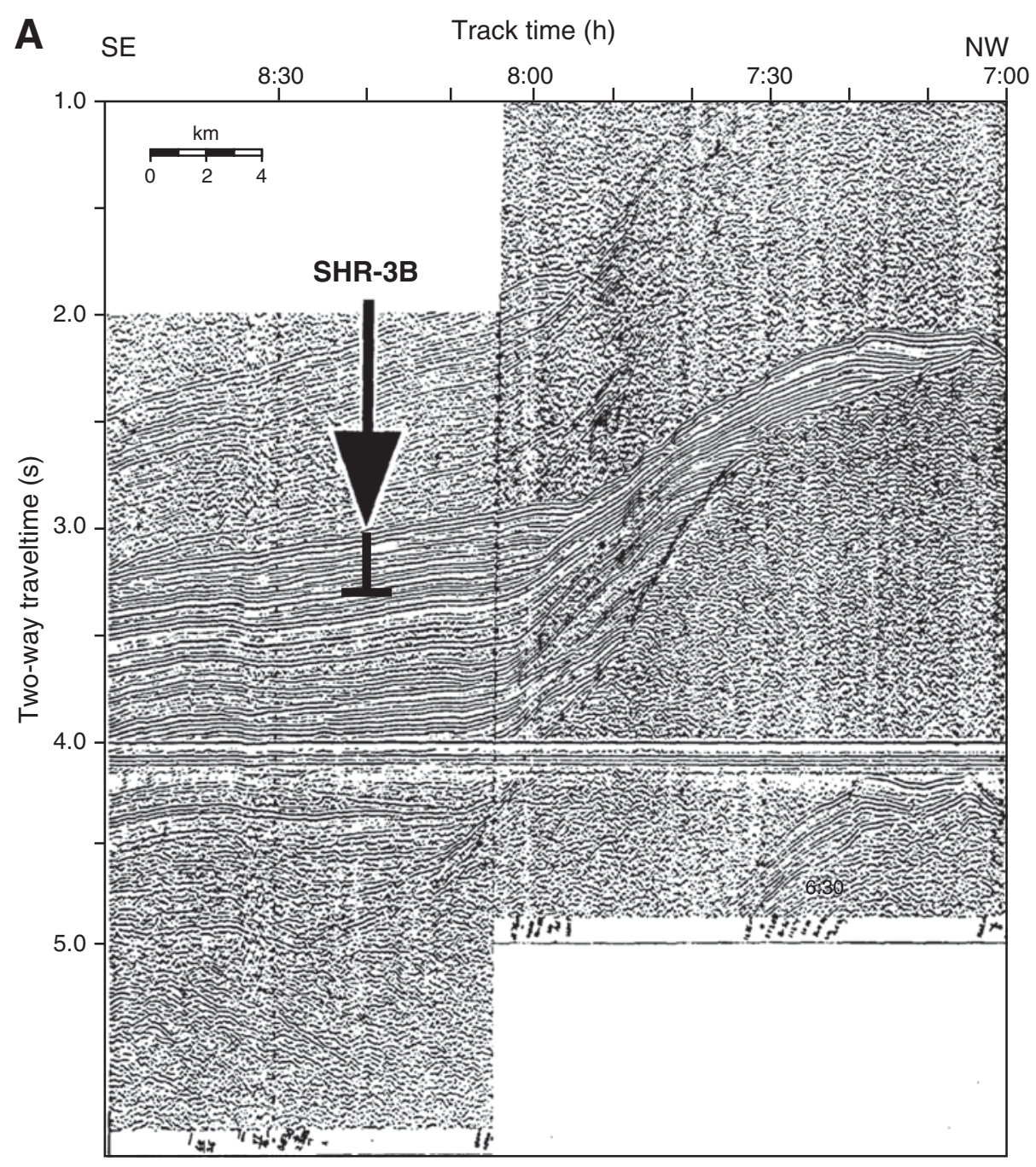

B

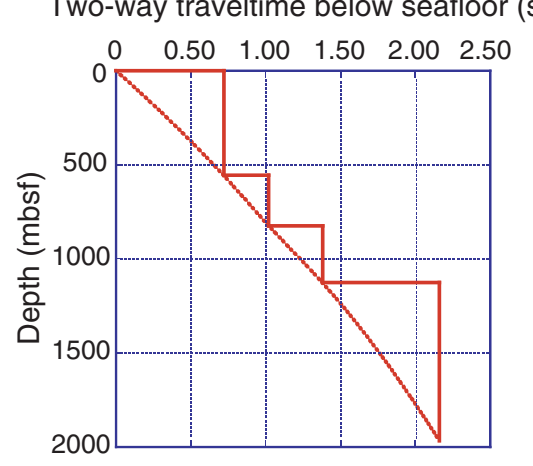




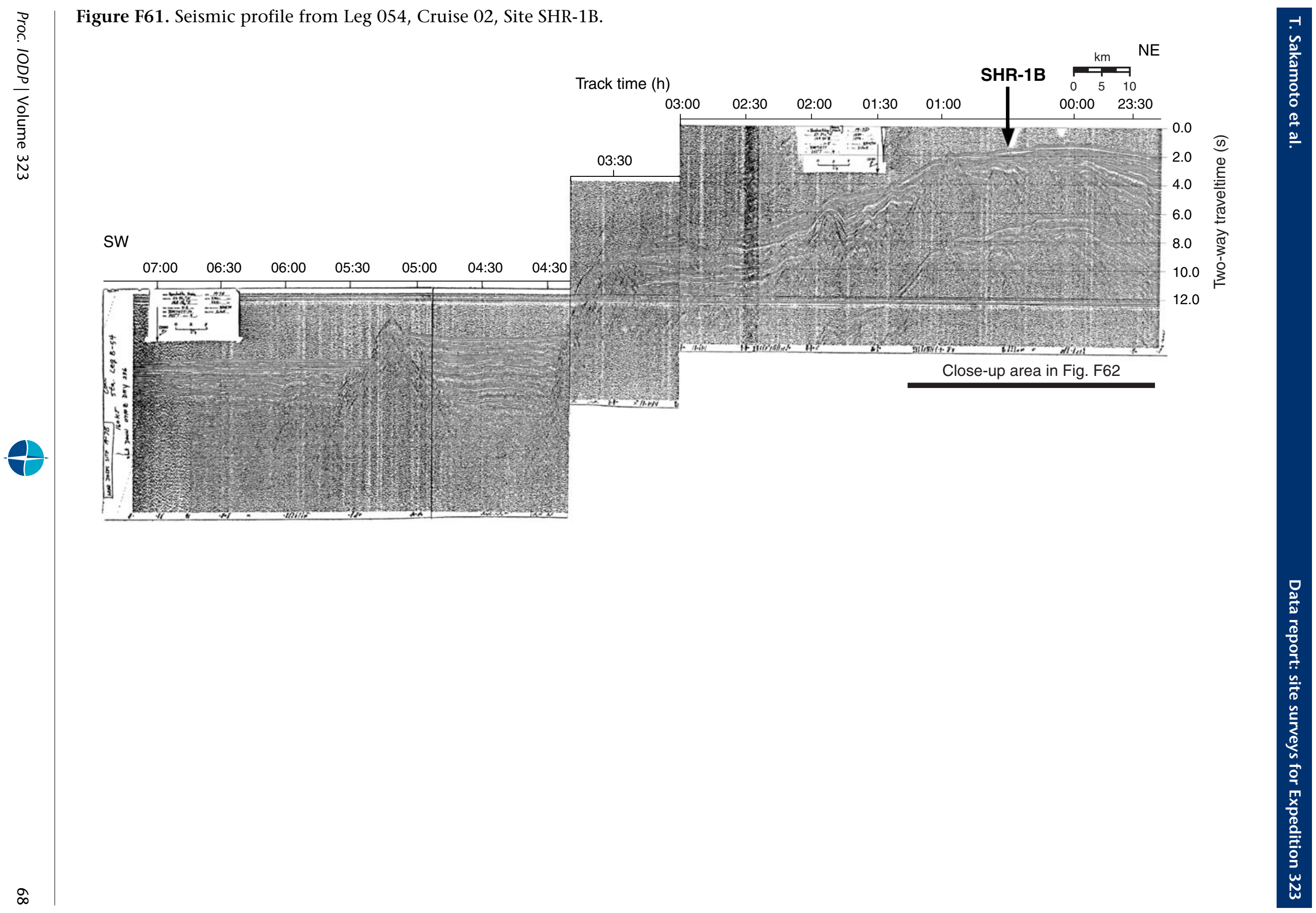


Figure F62. A. Close-up seismic profile of Leg 054, Cruise 02, Site SHR-1B. B. Time-depth conversion curve used for Site SHR-1B.

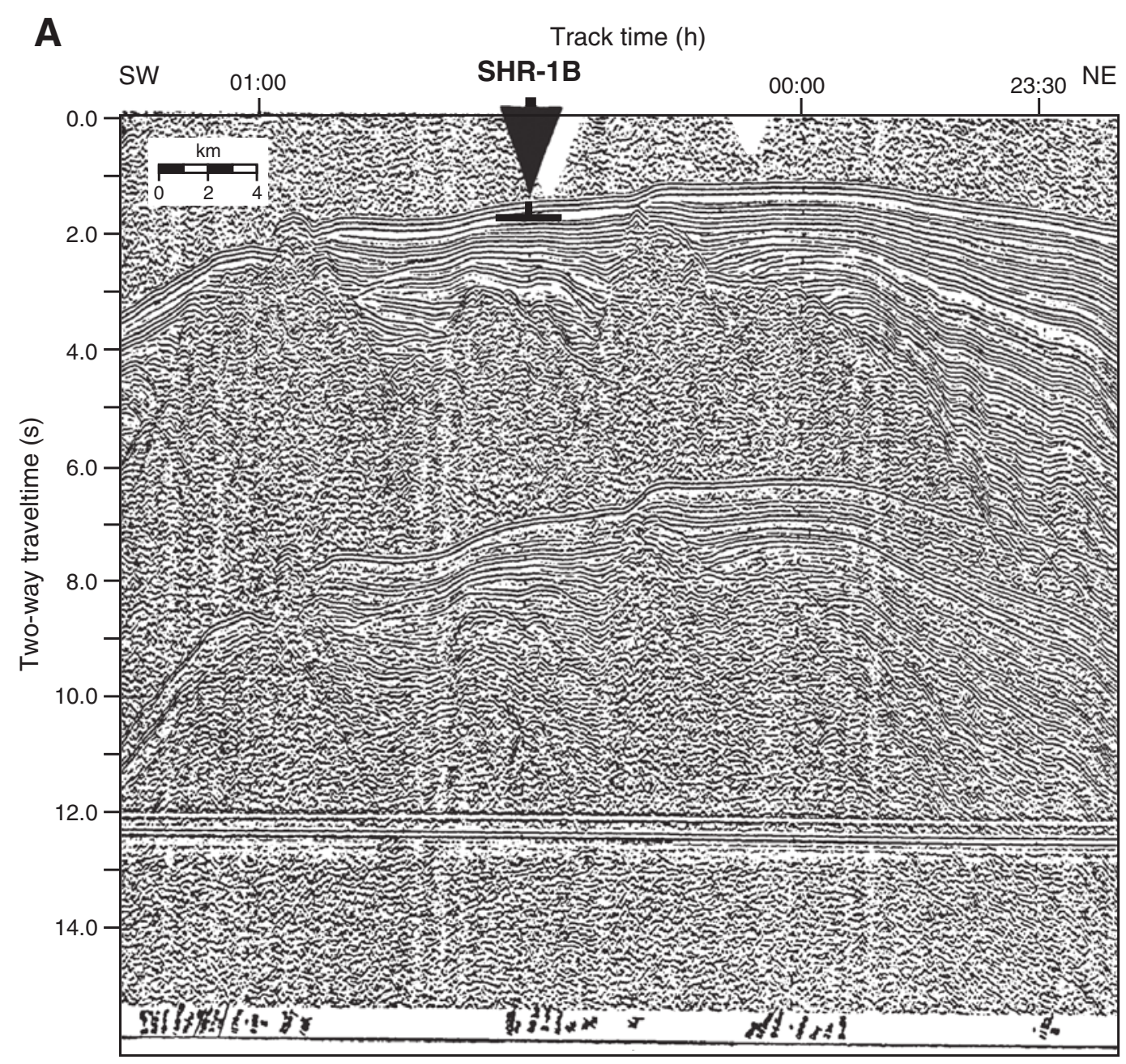

B Two-way traveltime below seafloor (s)

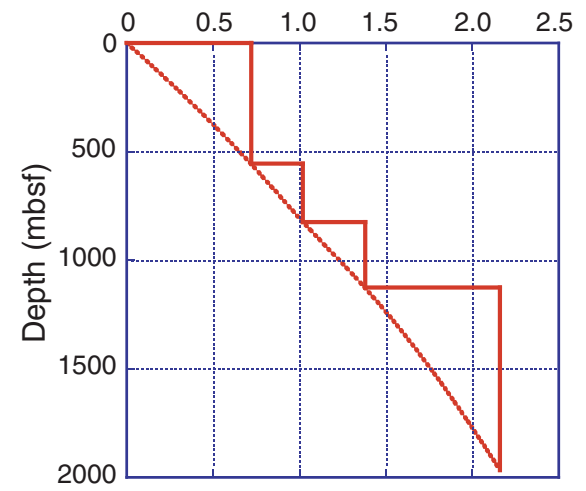


Figure F63. Regional overview map, Site KST-1B.

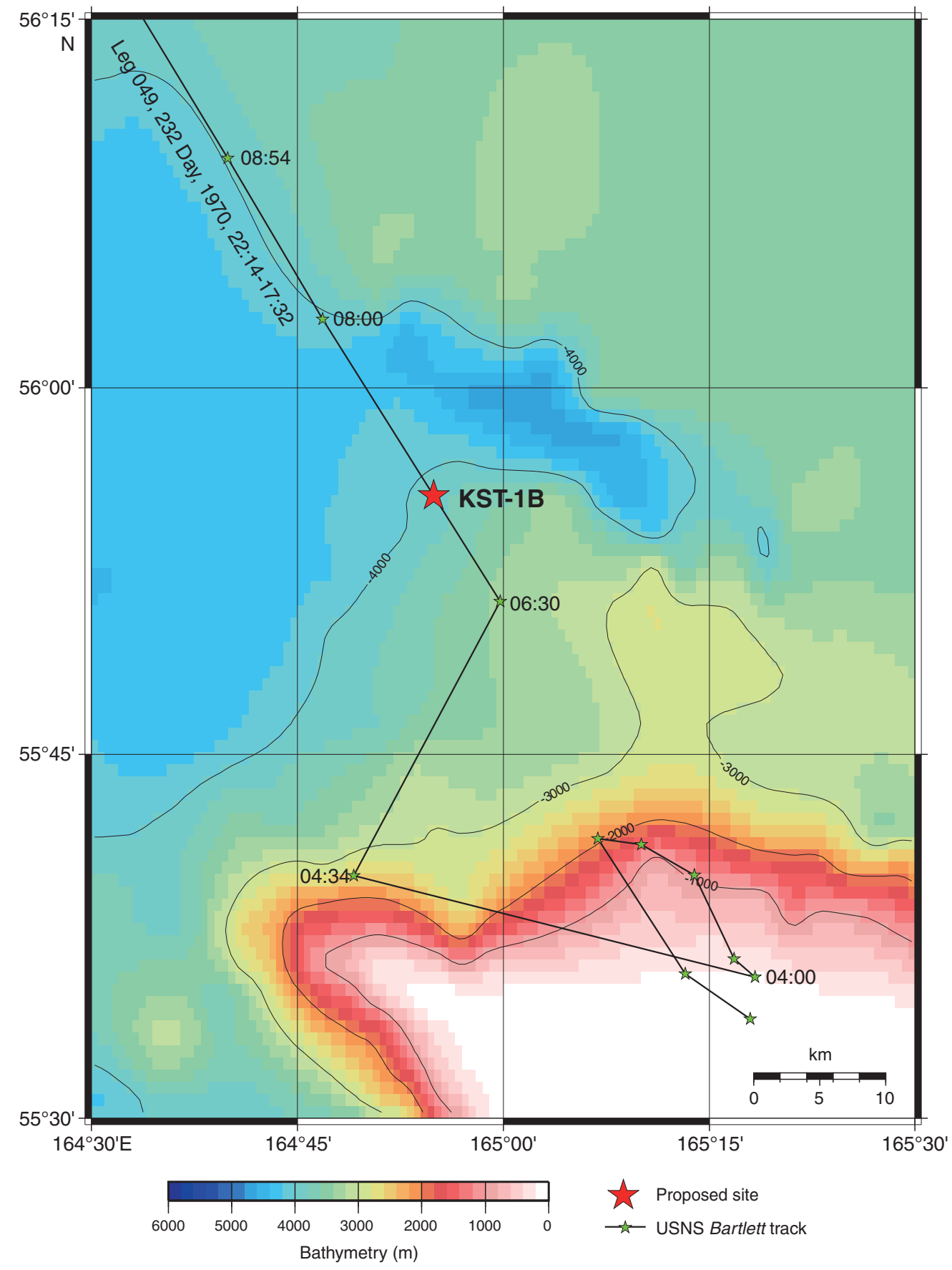




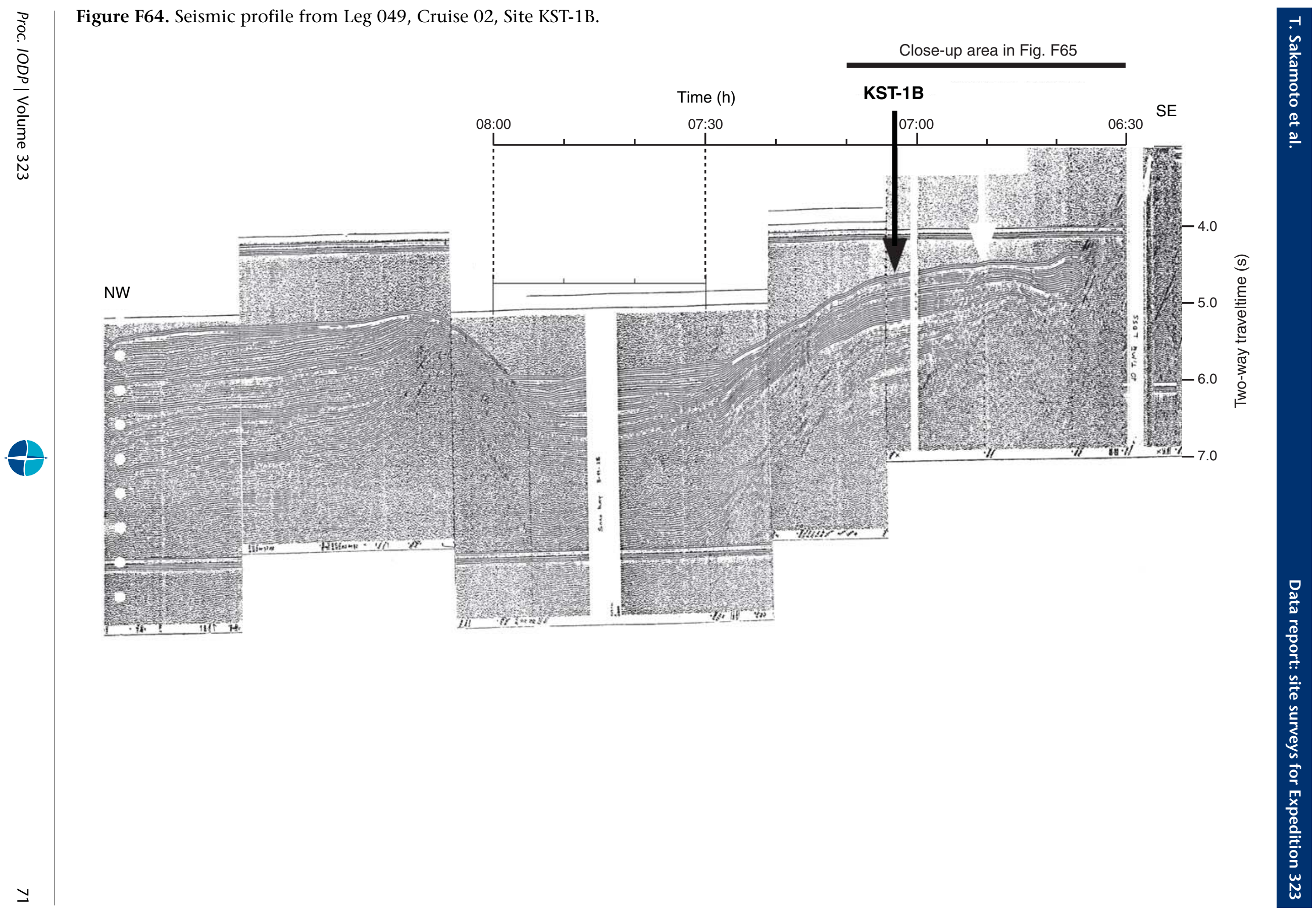


Figure F65. Close-up seismic profile of Leg 049, Cruise 02, Site KST-1B.

Time (h)

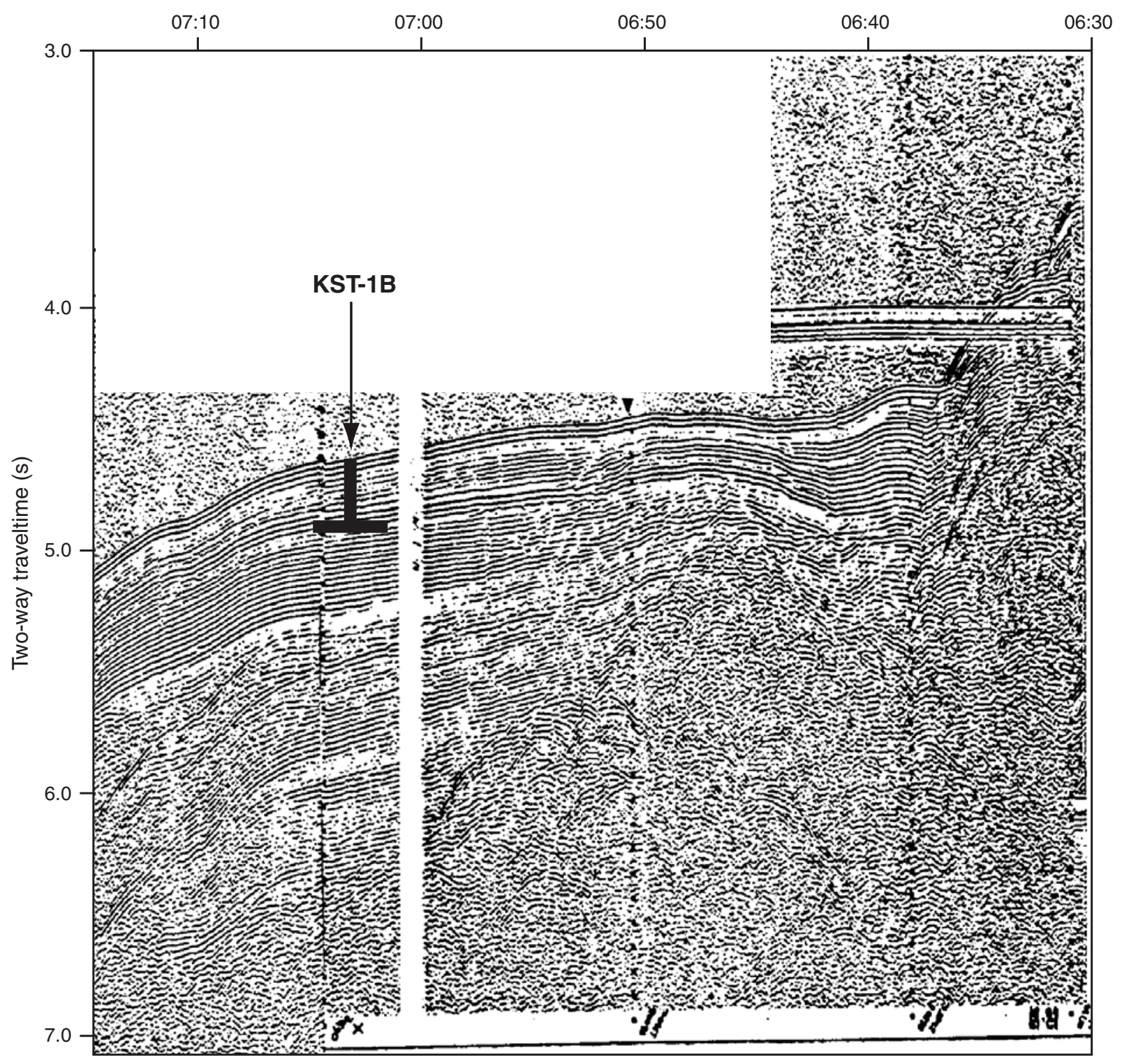


Table T1. Expedition 323 drill sites and Proposal 477 proposed drill sites. (See table notes.)

\begin{tabular}{|c|c|c|c|c|c|c|c|c|}
\hline Drilled site & Proposed site & Latitude & Longitude & $\begin{array}{l}\text { Water depth } \\
\text { (mbsl) }\end{array}$ & $\begin{array}{l}\text { Penetration } \\
\text { (mbsf) }\end{array}$ & $\begin{array}{c}\text { Estimated } \\
\text { sedimentation } \\
\text { rate }(\mathrm{cm} / \mathrm{k} . \mathrm{y} .)\end{array}$ & $\begin{array}{l}\text { Estimated } \\
\text { bottom age } \\
(\mathrm{Ma})\end{array}$ & $\begin{array}{l}\text { Drilling } \\
\text { priority }\end{array}$ \\
\hline \multicolumn{9}{|c|}{ Bering Sea (high-priority sites) } \\
\hline \multicolumn{9}{|l|}{ Umnak Plateau } \\
\hline U1339 & UMK-4D & $54^{\circ} 41.1^{\prime} \mathrm{N}$ & $169^{\circ} 58.0^{\prime} \mathrm{W}$ & 1885 & 200 & 13 & - & High \\
\hline Not drilled & UMK-3B & $54^{\circ} 25.1^{\prime} \mathrm{N}$ & $170^{\circ} 14.6^{\prime} \mathrm{W}$ & 1898 & 200 & 12.9 & 1.6 & H-Alt \\
\hline \multicolumn{9}{|l|}{ Bowers Ridge } \\
\hline U1340 & BOW-12B & $53^{\circ} 24.0^{\prime} \mathrm{N}$ & $179^{\circ} 31.3^{\prime} \mathrm{W}$ & 1313 & 745 & 8.4 & 8.3 & High \\
\hline U1341 & BOW-14B & $54^{\circ} 02.0^{\prime} \mathrm{N}$ & $179^{\circ} 00.5^{\prime} \mathrm{E}$ & 2166 & 600 & 12.6 & 5.6 & High \\
\hline U1342 & BOW-15A & $54^{\circ} 49.7^{\prime} \mathrm{N}$ & $176^{\circ} 55.0^{\prime} \mathrm{E}$ & 837 & 165 & 3.2 & 3.0 & High \\
\hline \multicolumn{9}{|l|}{ Gateway } \\
\hline U1343 & GAT-4C & $57^{\circ} 34.6^{\prime} \mathrm{N}$ & $175^{\circ} 45.2^{\prime} \mathrm{W}$ & 1853 & 745 & 8.0 & 8.8 & High \\
\hline U1344 & GAT-3C & $59^{\circ} 03.0^{\prime} \mathrm{N}$ & $179^{\circ} 10.0^{\prime} \mathrm{W}$ & 3158 & 745 & 9.1 & 7.7 & High \\
\hline \multicolumn{9}{|l|}{ Shirshov Ridge } \\
\hline Not drilled & SHR-3B & $56^{\circ} 26.1^{\prime} \mathrm{N}$ & $170^{\circ} 37.2^{\prime} \mathrm{E}$ & 2232 & 200 & 8.0 & 2.5 & High \\
\hline Not drilled & SHR-1B & $57^{\circ} 19.0^{\prime} \mathrm{N}$ & $170^{\circ} 06.4^{\prime} \mathrm{E}$ & 963 & 200 & 8.0 & 2.5 & H-Alt \\
\hline \multicolumn{9}{|l|}{ Kamchatka Strait } \\
\hline Not drilled & KST-1B & $55^{\circ} 55.6^{\prime} \mathrm{N}$ & $164^{\circ} 54.9^{\prime} \mathrm{E}$ & 3435 & 200 & - & - & Inter \\
\hline \multicolumn{9}{|l|}{ Okhotsk Sea } \\
\hline \multicolumn{9}{|l|}{ Academy of Sciences Rise } \\
\hline Not drilled & ASR-3B & $48^{\circ} 58.7^{\prime} \mathrm{N}$ & $150^{\circ} 26.4^{\prime} \mathrm{E}$ & 1422 & 700 & 14 & 5.0 & High \\
\hline Not drilled & ASR-4B & $48^{\circ} 45.0^{\prime} \mathrm{N}$ & $151^{\circ} 13.5^{\prime} \mathrm{E}$ & 2025 & 200 & 14 & 1.4 & High \\
\hline Not drilled & ASR-1C & $49^{\circ} 04.4^{\prime} \mathrm{N}$ & $150^{\circ} 34.4^{\prime} \mathrm{E}$ & 1396 & 245 & 38 & 0.5 & H-Alt \\
\hline Not drilled & ASR-2B & $48^{\circ} 35.6^{\prime} \mathrm{N}$ & $150^{\circ} 55.8^{\prime} \mathrm{E}$ & 2175 & 245 & 18 & 3.9 & H-Alt \\
\hline \multicolumn{9}{|l|}{ Central Okhotsk Plateau } \\
\hline Not drilled & COP-2E & $51^{\circ} 59.0^{\prime} \mathrm{N}$ & $147^{\circ} 10.4^{\prime} \mathrm{E}$ & 1320 & 745 & 10 & 7.0 & High \\
\hline Not drilled & COP-2F & $52^{\circ} 03.1^{\prime} \mathrm{N}$ & $147^{\circ} 01.4^{\prime} \mathrm{E}$ & 1345 & 200 & 10 & 2.0 & H-Alt \\
\hline \multicolumn{9}{|l|}{ Off Kamchatka Peninsula } \\
\hline Not drilled & KAM-2B & $52^{\circ} 14.2^{\prime} \mathrm{N}$ & $153^{\circ} 02.3^{\prime} \mathrm{E}$ & 610 & 200 & 6.6 & 3.0 & High \\
\hline \multicolumn{9}{|l|}{ Pegasus Rise } \\
\hline Not drilled & PGR-2A & $47^{\circ} 52.9^{\prime} \mathrm{N}$ & $147^{\circ} 13.7^{\prime} \mathrm{E}$ & 2544 & 445 & 15 & 1.3 & High \\
\hline \multicolumn{9}{|l|}{ Off Sakhalin islands } \\
\hline Not drilled & SAK-2B & $51^{\circ} 19.5^{\prime} \mathrm{N}$ & $145^{\circ} 55.5^{\prime} \mathrm{E}$ & 970 & 200 & 10 & 2.0 & Inter \\
\hline
\end{tabular}

Notes: High = highest priority, $\mathrm{H}-\mathrm{Alt}=$ high-priority alternate, Inter = secondary priority. - = no data. 
Table T2. Multichannel seismic survey observational parameters, Cruise KH99-03 Leg 3.

\begin{tabular}{ll}
\hline Air guns & Two of Bolts' 1900C \\
Firing pressure (atm) & 100 \\
Chamber volume $\left(\mathrm{cm}^{3}\right)$ & 1800 (port) \\
& 3000 (starboard) \\
Streamer cable & \\
Number of channels & 24 \\
Length (m) & $600(25 \mathrm{~m} \times 24$ channels) \\
Length of lead-in cable (m) & 100 \\
Conditions & \\
Shot intervals (s) & 14 (in case) \\
Record length (s) & 8 \\
Sampling intervals (ms) & 2 \\
Delay time for data acquisition (s) & 0 \\
Number of birds & 4 (every 4 channels from the ship side of the streamer) \\
Bird depth (m) & 10 \\
Preamp gain (dB) & 48 \\
Tape format & SEG-D \\
\hline
\end{tabular}

